Water Availability and Use Science Program

Hydrogeologic Framework and Groundwater Characterization in Selected Alluvial Basins in the Upper Rio Grande Basin, Colorado, New Mexico, and Texas, United States, and Chihuahua, Mexico, 1980 to 2015
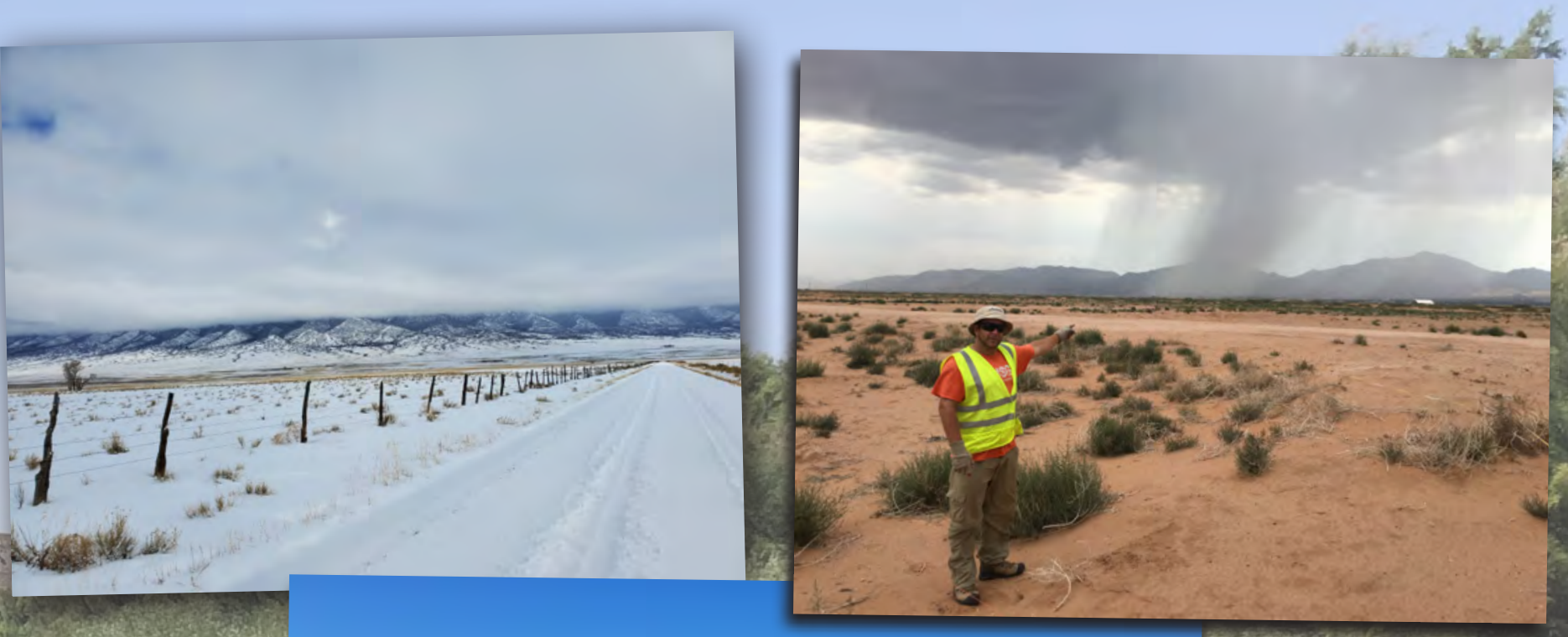

Scientific Investigations Report 2021-5035 
Cover background. View of the Mesilla Valley reach of the Rio Grande from bridge FM259 at the Leasburg Dam State Park, New Mexico, downstream to Canutillo, Texas, in June 2020; photograph by Scott Ikard, U.S. Geological Survey (USGS).

Front cover. [Top left] Snow in the Sangres de Cristo mountains, viewed from the San Luis Valley, Colorado, in January 2021; photograph by Zachary Kisfalusi, USGS. [Top right] Desert monsoon over the Franklin Mountains (in the distance) near El Paso, Tx., in July 2018; photograph by Delbert Humberson, USGS. [Bottom] A kayaker on the Mesilla Valley reach of the Rio Grande, viewed from bridge FM259 at the Leasburg Dam State Park in New Mexico, downstream to Canutillo, Tx., in June 2020; photograph by Scott Ikard, USGS.

Back cover. [Top] Sunset in the San Luis Valley, Colo., in January 2021; photograph by Zachary Kisfalusi, USGS. [Middle] Cataraft on the shore at Leasburg Dam State Park, N. Mex., in June 2020; photograph by Scott Ikard, USGS. [Bottom] View of the Franklin Mountains (in the distance) over a desert pond near El Paso, Tx., in September 2016; photograph by Delbert Humberson, USGS. 


\section{Hydrogeologic Framework and Groundwater Characterization in Selected Alluvial Basins in the Upper Rio Grande Basin, Colorado, New Mexico, and Texas, United States, and Chihuahua, Mexico, 1980 to 2015}

By Natalie A. Houston, Jonathan V. Thomas, Linzy K. Foster, Diana E. Pedraza, and Toby L. Welborn

Water Availability and Use Science Program

Scientific Investigations Report 2021-5035 


\section{U.S. Geological Survey, Reston, Virginia: 2021}

For more information on the USGS - the Federal source for science about the Earth, its natural and living resources, natural hazards, and the environment—visit https://www.usgs.gov or call 1-888-ASK-USGS.

For an overview of USGS information products, including maps, imagery, and publications, visit https://store.usgs.gov/.

Any use of trade, firm, or product names is for descriptive purposes only and does not imply endorsement by the U.S. Government.

Although this information product, for the most part, is in the public domain, it also may contain copyrighted material and images protected by publicity rights. Use of photographs or images may require permission to reproduce copyrighted items or the likeness of a person. Permission must be secured from the copyright owner or person whose likeness is being used. For more information, visit https://usgs.gov/copyright.

Suggested citation:

Houston, N.A., Thomas, J.V., Foster, L.K., Pedraza, D.E., and Welborn, T.L., 2021, Hydrogeologic framework and groundwater characterization in selected alluvial basins in the upper Rio Grande basin, Colorado, New Mexico, and Texas, United States, and Chihuahua, Mexico, 1980 to 2015: U.S. Geological Survey Scientific Investigations Report 2021-5035, 71 p., https://doi.org/10.3133/sir20215035.

Data associated with the publication:

Houston, N.A., Pedraza, D.E., Thomas, J.V., Foster, L.K., and Welborn, T.L., 2020, Hydrogeologic, geologic, and waterlevel data for the groundwater component of the upper Rio Grande focus area study, Colorado, New Mexico, and Texas, United States, and Chihuahua, Mexico, 2017: U.S. Geological Survey data release, https://doi.org/10.5066/ F7N58KBS.

ISSN 2328-0328 (online) 


\section{Acknowledgments}

The authors thank Dagmar Llewellyn with the Bureau of Reclamation for her support in the development of this study and her assistance in obtaining data and resources throughout the study duration. The authors also thank Alex Rinehart with the New Mexico Bureau of Geology and Mineral Resources for his assistance in acquiring groundwater-level data for New Mexico and sharing his expertise of the hydrogeology of New Mexico.

The authors thank Tien Grauch with the U.S. Geological Survey (USGS) for sharing her expertise of the structure and geology of the Rio Grande Basin and her assistance in completing a digital version of the Rio Grande alluvial basin boundaries. The authors also thank Erick R. Burns, William H. Asquith, and David S. Wallace with the USGS for providing statistical software and expertise for analyses completed during this study. 



\section{Contents}

Acknowledgments ……...................................................................................................................

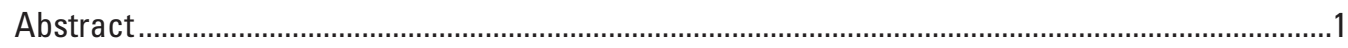

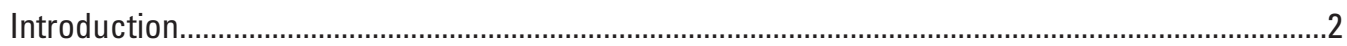

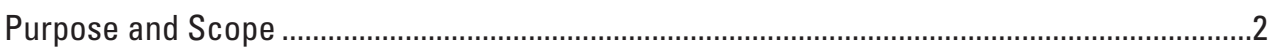

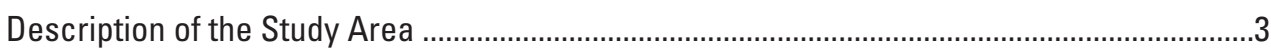

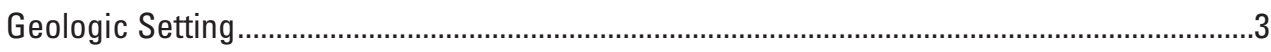

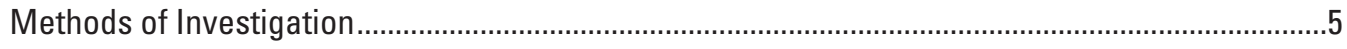

Development of Alluvial Basin Boundaries ..........................................................................

Data Compilation and Refinement .........................................................................................

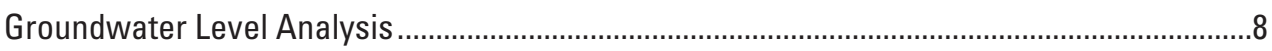

Groundwater Storage Estimation Methodology ....................................................................

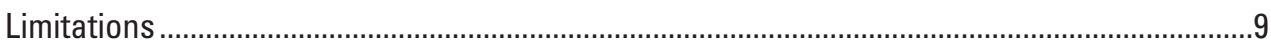

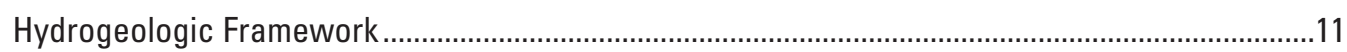

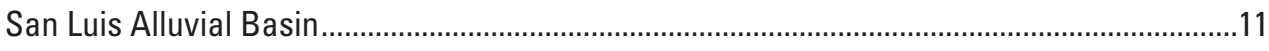

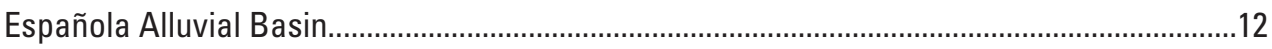

Middle Rio Grande Alluvial Basin .....................................................................................

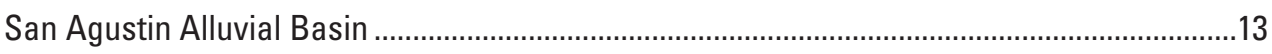

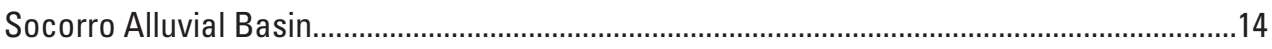

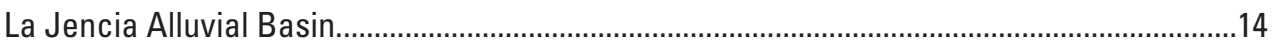

San Marcial Alluvial Basin .....................................................................................................

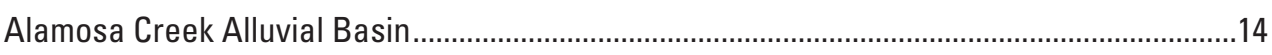

Engle Alluvial Basin .................................................................................................. 14

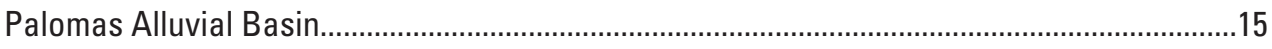

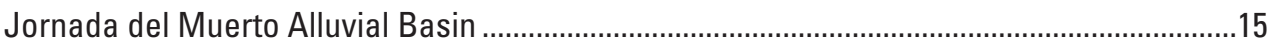

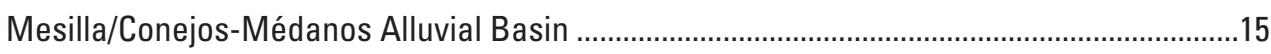

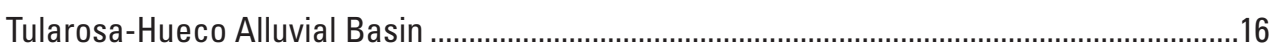

Groundwater Level and Estimated Groundwater Storage Change Analysis....................................16

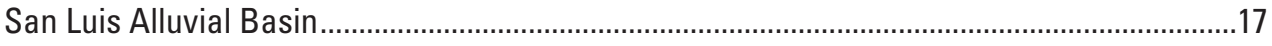

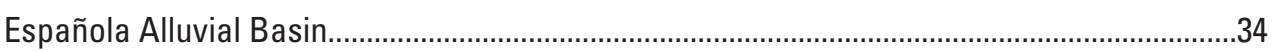

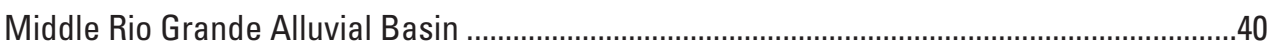

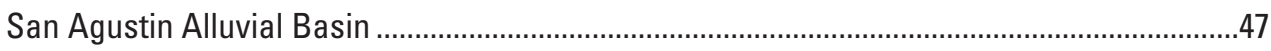

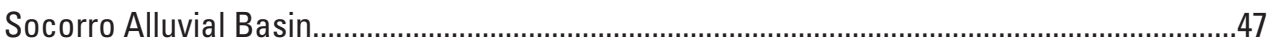

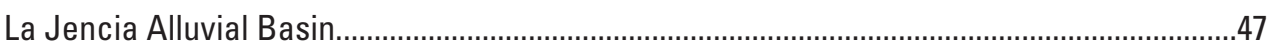

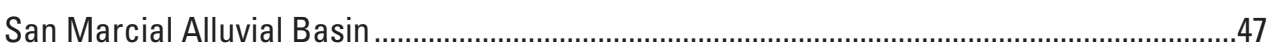

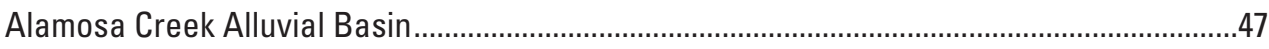

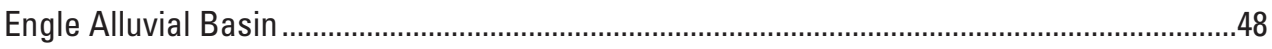

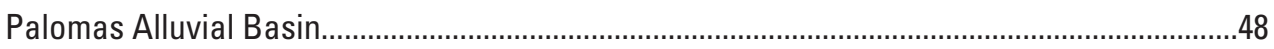

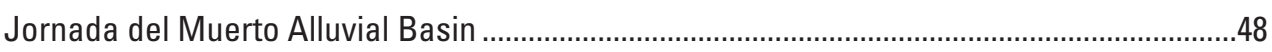

Mesilla/Conejos-Médanos Alluvial Basin ............................................................................

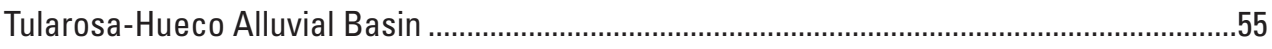

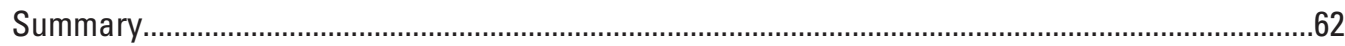

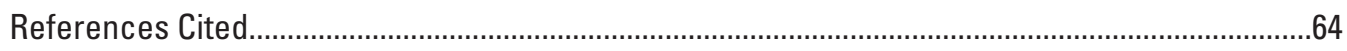




\section{Figures}

1. Map showing extent of alluvial basins and locations of selected cross-section profiles in the upper Rio Grande Basin in Colorado, New Mexico, and Texas, United States, and Chihuahua, Mexico.

2. Maps showing wells with groundwater-level measurements made from 1980 to 2015 in the upper Rio Grande Basin.

3. Map showing the spatial extent of area included in groundwater-storage computations based on groundwater levels for alluvial basins in the upper Rio Grande Basin

4. Map showing median 1980 groundwater-level altitude for the upper Rio Grande alluvial basins from November 1977 through March 1982.

5. Map showing median 1985 groundwater-level altitude for the upper Rio Grande alluvial basins from November 1982 through March 1987

6. Map showing median 1990 groundwater-level altitude for the upper Rio Grande alluvial basins from November 1987 through March 1992

7. Map showing median 1995 groundwater-level altitude for the upper Rio Grande alluvial basins from November 1992 through March 1997

8. Map showing median 2000 groundwater-level altitude for the upper Rio Grande alluvial basins from November 1997 through March 2002.

9. Map showing median 2005 groundwater-level altitude for the upper Rio Grande alluvial basins from November 2002 through March 2007

10. Map showing median 2010 groundwater-level altitude for the upper Rio Grande alluvial basins from November 2007 through March 2012

11. Map showing median 2000 groundwater-level altitude for the upper Rio Grande alluvial basins from November 1997 through March 2002

12. Map showing approximate groundwater-level changes at wells in the upper Rio Grande alluvial basins

13. Maps showing median groundwater-level changes for the San Luis alluvial basin in 1980-85 and 1985-90 in Colorado and New Mexico.

14. Maps showing median groundwater-level changes for the San Luis alluvial basin in 1990-95 and 1995-2000 in Colorado and New Mexico.

15. Maps showing median groundwater-level changes for the San Luis alluvial basin in 2000-05 and 2005-10 in Colorado and New Mexico.

16. Maps showing median groundwater-level changes for the San Luis alluvial basin in 2010-15 and 1980-2015 in Colorado and New Mexico

17. Graph showing ranges of groundwater-storage changes for the San Luis alluvial basin for 5 -year periods and cumulative storage change from 1980 to 2015 .....32

18. Graph showing simulated changes in groundwater storage in the San Luis Basin, Colorado

19. Graph showing cumulative storage changes for San Luis Basin, Colorado, during 1970-2010.

20. Graph showing selected simulated inflows and outflows within the San Luis Basin, Colorado

21. Maps showing median groundwater-level changes for the Española alluvial basin in 1980-85 and 1985-90 in New Mexico.

22. Maps showing median groundwater-level changes for the Española alluvial basin in 1990-95 and 1995-2000 in New Mexico. 
23. Maps showing median groundwater-level changes for the Española alluvial basin 2000-05 and 2005-10 in New Mexico

24. Maps showing median groundwater-level changes for the Española alluvial basin in 2010-15 and 1980-2015 in New Mexico

25. Graph showing ranges of groundwater storage changes for the Española alluvial basin for 5 -year periods and cumulative storage change from 1980 to 2015 .....39

26. Graph showing simulated annual outflows from groundwater storage in the Tesuque aquifer in the Española Basin

27. Maps showing median groundwater-level changes for the Middle Rio Grande alluvial basin in 1980-85 and 1985-90 in New Mexico

28. Maps showing median groundwater-level changes for the Middle Rio Grande alluvial basin in 1990-95 and 1995-2000 in New Mexico

29. Maps showing median groundwater-level changes for the Middle Rio Grande alluvial basin in 2000-05 and 2005-10 in New Mexico

30. Maps showing median groundwater-level changes for the Middle Rio Grande alluvial basin in 2010-15 and 1980-2015 New Mexico . .44

31. Graph showing ranges of groundwater-storage changes for the Middle Rio Grande alluvial basin for 5 -year periods and cumulative storage change from 1980 to 2015.

32. Graph showing simulated inflows to and outflows from groundwater in storage from 1900 to 2009 in the Santa Fe Group aquifer system in the Middle Rio Grande alluvial basin

33. Graph showing ranges of groundwater-storage changes for the Palomas alluvial basin for 5-year periods and cumulative storage change from 1980 to 2015 .....49

34. Maps showing median groundwater-level changes for the Mesilla/ Conejos-Médanos alluvial basin in 1980-85 and 1985-90

35. Maps showing median groundwater-level changes for the Mesilla/ Conejos-Médanos alluvial basin in 1990-95 and 1995-2000

36. Maps showing median groundwater-level changes for the Mesilla/ Conejos-Médanos alluvial basin in 2000-05 and 2005-10

37. Maps showing median groundwater-level changes for the Mesilla/ Conejos-Médanos alluvial basin in 2010-15 and 1980-2015

38. Graph showing ranges of groundwater-storage changes for the Mesilla/ Conejos-Médanos alluvial basin for 5 -year periods and cumulative storage change from 1980 to 2015

39. Graph showing simulated groundwater flow values for the hydrologic-flow budget from the Rio Grande Transboundary Integrated Hydrologic Model

40. Maps showing median groundwater-level changes for the Tularosa-Hueco alluvial basin in 1980-85 and 1985-90

41. Maps showing median groundwater-level changes for the Tularosa-Hueco alluvial basin in 1990-95 and 1995-2000

42. Maps showing median groundwater-level changes for the Tularosa-Hueco alluvial basin in 2000-05 and 2005-10

43. Graph showing ranges of groundwater-storage changes for the Tularosa-Hueco alluvial basin for 5 -year periods and cumulative storage change from 1980 to 2015

44. Graph showing simulated annual inflows to and outflows from groundwater storage in the Hueco Bolson aquifer. 


\section{Tables}

1. Selected cross sections representing one or more alluvial basins in the upper Rio Grande Basin, in Colorado, New Mexico, Texas, and Mexico

2. Median slope of 5-year median groundwater-level altitudes for alluvial basins in the upper Rio Grande Basin in Colorado, New Mexico, and Texas, United States, and in Mexico, from 1980 to 2015.

3. Minimum, median, and maximum groundwater-level altitude change for wells that have groundwater-level data for both time periods being evaluated for alluvial basins in the upper Rio Grande Basin, in Colorado, New Mexico, Texas, and Mexico.

\section{Conversion Factors}

U.S. customary units to International System of Units

\begin{tabular}{lcl}
\hline \multicolumn{1}{c}{ Multiply } & By & \multicolumn{1}{c}{ To obtain } \\
\hline inch (in.) & 25.4 & millimeter $(\mathrm{mm})$ \\
foot $(\mathrm{ft})$ & 0.3048 & meter $(\mathrm{m})$ \\
mile $(\mathrm{mi})$ & 1.609 & kilometer $(\mathrm{km})$ \\
acre & 4,047 & square meter $\left(\mathrm{m}^{2}\right)$ \\
square mile $\left(\mathrm{mi}^{2}\right)$ & 2.59 & square kilometer $\left(\mathrm{km}^{2}\right)$ \\
acre-foot $(\mathrm{ac}-\mathrm{ft})$ & 1,233 & cubic meter $\left(\mathrm{m}^{3}\right)$ \\
gallon per minute $(\mathrm{gal} / \mathrm{min})$ & 0.06309 & liter per second $(\mathrm{L} / \mathrm{s})$ \\
gallon per day $(\mathrm{gal} / \mathrm{d})$ & 0.003785 & cubic meter per day $\left(\mathrm{m}^{3} / \mathrm{d}\right)$ \\
\hline
\end{tabular}

\section{Datums}

Vertical coordinate information is referenced to the North American Vertical Datum of 1988 (NAVD 88).

Horizontal coordinate information is referenced to the North American Datum of 1983 (NAD 83). Altitude, as used in this report, refers to distance above the vertical datum.

\section{Abbreviations}
RGDSS
Rio Grande Decision Support System
USGS
U.S. Geological Survey 


\title{
Hydrogeologic Framework and Groundwater Characterization in Selected Alluvial Basins in the Upper Rio Grande Basin, Colorado, New Mexico, and Texas, United States, and Chihuahua, Mexico, 1980 to 2015
}

\author{
By Natalie A. Houston, Jonathan V. Thomas, Linzy K. Foster, Diana E. Pedraza, and Toby L. Welborn
}

\section{Abstract}

Increasing demand for the limited water resources of the United States continues to put pressure on resource management agencies to balance the competing needs of ecosystem health with municipal, agricultural, and other uses. To meet these needs, the U.S. Geological Survey conducted a multiyear study to evaluate water resources in the upper Rio Grande Basin in the southwestern United States. The upper Rio Grande Basin extends from south-central Colorado, through New Mexico, into west Texas near Fort Quitman, including parts of Chihuahua, Mexico. The upper Rio Grande Basin consists of a sequence of alluvial basins that formed in the Rio Grande rift approximately 30 million years ago.

This report describes the hydrogeology of the upper Rio Grande Basin and how the groundwater resources in the basin have changed from 1980 to 2015 . The hydrogeologic framework includes the horizontal delineation of the alluvial basins within the upper Rio Grande Basin from the headwaters in Colorado to Fort Quitman, Texas, including part of Mexico. Groundwater-level measurements from existing State and Federal data were used to construct groundwater-level altitude and groundwater-level change maps.

Of the 2,699 wells with groundwater-level data used in this study, 1,055 wells had data for only a single 5 -year period, 703 wells had data for 50 percent or more of the 35 years of the study, and only 57 wells have 5-year groundwater-level data for the entire study period. The median decline in water levels in the upper Rio Grande Basin was 0.13 foot (ft) per 5 -year period, and declines were measured in 53 percent of the 703 wells that contained data for 50 percent or more of the study period. Rates of groundwater-level decline greater than $1 \mathrm{ft}$ per 5 -year period were measured in 17 percent of the wells, greater than $2 \mathrm{ft}$ per 5-year period, in 3 percent of the wells, and greater than $3 \mathrm{ft}$ per 5 -year period, in 1 percent of the wells. Overall, groundwater levels rose in 6 percent of the 703 wells that contained data for 50 percent or more of the study period, and in 4 percent of the wells, groundwater levels rose by $1 \mathrm{ft}$ or more per 5 -year period.
Groundwater-level changes in wells with consecutive 5-year measurement periods exhibited the most variability in the Española, Middle Rio Grande, and Mesilla/ Conejos-Médanos alluvial basins. The largest declines in groundwater-level altitudes in individual wells were observed in the Española alluvial basin during 1995-2000, in the Palomas alluvial basin during 2010-2015, and in the Jornada del Muerto alluvial basin during 2005-10. The largest rises in groundwater-level altitudes in individual wells were observed in the Española alluvial basin during 2005-10, in the Middle Rio Grande alluvial basin during 1995-2000, and in the Mesilla/Conejos-Médanos alluvial basin during 1980-85.

Changes in groundwater storage throughout the study period varied by alluvial basin, likely based largely on changes in groundwater withdrawals because of increased demands during drier periods and population growth. All alluvial basins except the Tularosa-Hueco alluvial basin were evaluated for changes in groundwater storage from 1980 to 2015. Extremely limited data availability in $2010-15$ for the Tularosa-Hueco alluvial basin led to this 5-year period being dropped from the groundwater-level change map and storage analysis for this basin.

In the San Luis Valley in southern Colorado, efforts to reverse groundwater depletion in the unconfined aquifer recovered approximately 250,000 acre-feet in storage between late 2013 and early 2018, following the implementation of a "payto-pump" groundwater program. However, severe drought that persists in the upper Rio Grande Basin, particularly in southern Colorado, has undone some of the conservation efforts. Within the Española alluvial basin, groundwater storage varied because municipal demand increased the demand on groundwater resources and conservation efforts were implemented. A groundwater-flow model evaluated for the Española alluvial basin indicated declines in groundwater storage from 1947 through 1982. Groundwater storage decreased in the Española alluvial basin in 1980-85, 1985-90, 1990-95, 1995-2000, and 2005-10 and increased in 2000-05 and 2010-15 leading to groundwater storage in 2015 about even with that in 1985. 
Based on gridded groundwater-level altitudes, groundwater storage decreased in the Middle Rio Grande Basin from 1980 to 2015 , except for during the 1980-85, 2000-05, and 2010-15 periods with an overall cumulative storage decrease from 1980 to 2015. Groundwater-flow models evaluated for the Middle Rio Grande alluvial basin showed groundwater storage in the Middle Rio Grande alluvial basin has been reduced since the mid-1950s through the end of the study period except for a brief recovery (reduction in storage outflow) in the mid-1980s. Simulated groundwater storage has also decreased in parts of the Palomas and Mesilla/ Conejos-Médanos alluvial basins, and the northern part of the Conejos-Médanos alluvial basin starting in 1995 (excluding 2005 and 2007) and in the Tularosa-Hueco alluvial basin from the early 1940s to the end of the study period. Groundwater storage increased in the Mesilla/Conejos-Médanos alluvial basin during 1980-85 and slightly during 1990-95 and then decreased in the other 5-year periods. Groundwater storage in the Tularosa-Hueco alluvial basin increased from 1985 to 1990 , but otherwise decreased, leading to an overall net groundwater-level decline in this part of the basin from 1980 to 2010.

\section{Introduction}

Increasing demand for water resources of the United States continues to put pressure on resource management agencies to balance the competing needs of ecosystem health with municipal, agricultural, and other uses. The U.S. Geological Survey (USGS) National Water Census is a research program focused on water availability and use, authorized by subtitle F (Secure Water; 42 U.S.C. 10361 et seq.) of title IX of the Omnibus Public Land Management Act of 2009 (Public Law 111-11; 123 Stat. 991) and implemented through the U.S. Department of the Interior's WaterSMART initiative (U.S. Department of the Interior, 2021). The overarching purpose of WaterSMART is to develop data and tools needed by resource managers to meet challenges arising from increasingly scarce water availability caused by population growth, groundwater depletion, impaired water quality, aging infrastructure, climate variability and change, and the need to sustain environmental flows sufficient for a healthy ecosystem. The USGS is tasked with the technical aspects of providing information and tools to stakeholders so that they can make informed decisions on water availability; this effort requires the USGS to advance the science needed by stakeholders to assess ecological outcomes of management actions that change streamflow regimes and to forecast ecological conditions under future scenarios of water availability and management (Evenson and others, 2018).

As part of the WaterSMART initiative, the USGS completed a multiyear assessment to evaluate water resources in the upper Rio Grande Basin. This report focuses on selected aspects of the groundwater resources of the upper Rio Grande
Basin, which was defined as the part of the Rio Grande Basin that begins at the headwaters of the Rio Grande in southcentral Colorado and extends through New Mexico and northern Mexico before terminating in west Texas, near Fort Quitman, Tex. The focus of this report is on the alluvial basins in the upper Rio Grande Basin.

The upper Rio Grande Basin provides water resources for irrigation, municipal, environmental, and recreational uses in Colorado, New Mexico, and Texas, United States, and in Mexico. The amount of available water in the upper Rio Grande Basin has decreased as a result of decreased precipitation (primarily as snow), decreased reservoir storage, increased agricultural demands, and population growth (Bureau of Reclamation, 2016; Ivahnenko and others, 2021). The upper Rio Grande Basin either contains or is adjacent to several large cities that rely on groundwater resources from the basin or relied primarily on groundwater resources from the basin from 1980 to 2015, including Santa Fe, Albuquerque, and Las Cruces, N. Mex., El Paso, Tex., and Ciudad Juárez, Mexico. El Paso depends on the Rio Grande for approximately half of its water supply (Bureau of Reclamation, 2016).

The groundwater resource in the upper Rio Grande Basin is primarily the Santa Fe Group aquifer system. Groundwater enters the Santa Fe Group aquifer system from mountain-front recharge, seepage from the Rio Grande and its tributaries, transmission losses from conveyance structures, and irrigation return flow. Groundwater discharges from the Santa Fe Group aquifer system as well withdrawals, seepage into the Rio Grande and riverside drains, springs, evapotranspiration, and outflow to adjacent basins. When groundwater discharge from an aquifer exceeds recharge into the groundwater, groundwater-level altitudes in the aquifer decline, as is observed throughout the upper Rio Grande Basin. These declining groundwater-level altitudes can have adverse effects on long-term groundwater availability and sustainability, groundwater quality, and land subsidence.

\section{Purpose and Scope}

The purpose of this report is to document selected aspects of the groundwater resources of the upper Rio Grande Basin, such as the hydrogeologic framework of the alluvial basins as well as groundwater-level measurements and changes in estimated storage in the alluvial basins that compose the groundwater system of the upper Rio Grande Basin, and describe changes in groundwater resources from 1980 to 2015. The hydrogeologic framework includes the delineation of the horizontal extent of the interconnected alluvial basins within the upper Rio Grande Basin from the headwaters of the Rio Grande in Colorado to Fort Quitman in Texas, including a large part of New Mexico and part of Chihuahua in northern Mexico. Groundwater-level measurements were compiled from existing database resources and used to evaluate groundwater storage changes and construct groundwater-level altitude and groundwater-level change maps. 


\section{Description of the Study Area}

The upper Rio Grande Basin, as defined for this assessment, covers an area of about 32,000 square miles $\left(\mathrm{mi}^{2}\right)$ that extends from the headwaters of the Rio Grande in Colorado to Fort Quitman. The Rio Grande flows approximately 1,900 miles (mi) from its headwaters in the San Juan Mountains to the Gulf of Mexico; a reach of about $670 \mathrm{mi}$ of the Rio Grande is in the study area. The Rio Grande is known in Mexico as Río Bravo del Norte (fig. 1). Land surface altitudes in the study area range from approximately 3,400 to 12,000 feet (ft) above the North American Vertical Datum of 1988 (NAVD 88). The four major U.S. cities in the basin (Santa Fe, Albuquerque, Las Cruces, and El Paso) are at altitudes of about $6,800,5,000,3,900$ and $3,900 \mathrm{ft}$, respectively (U.S. Geological Survey, 2020). Adjacent to El Paso, Ciudad Juárez is the largest city in Mexico in the study and is approximately at the same altitude as El Paso.

The upper Rio Grande Basin is primarily in the Southern Rocky Mountains and Basin and Range physiographic provinces. According to Evenson and others (2018, p. 21), "the upper Rio Grande Basin is an arid to semiarid region where disputes over water shortages have been taking place for more than 100 years." There are several closed basins on either side of the main drainage that were not included in the study area. Basin topography varies from the forested mountains and river gorges of the headwaters to the riparian vegetation (referred to locally as bosque, the Spanish word for woodlands) of the broad valleys and high desert of central New Mexico to deserts along the boundary between Texas and Mexico (Llewellyn and Vaddey, 2013). Precipitation in the Rio Grande is highly variable, depending on latitude and land-surface altitude (Kunkel and others, 2013). Precipitation in the northern areas of the upper Rio Grande Basin is biseasonal, falling as snow in the mountains in winter and monsoonal rain in the summer. Mean annual precipitation ranges from more than 40 inches in the mountainous regions to about 10 inches in the valley along the Rio Grande (New Mexico Office of the State Engineer, 2016a-c). The initial years of the study period were characterized by warm, wet winters and erratic summer precipitation (Swetnam and Betancourt, 1998; Sheppard and others, 2002; Gutzler, 2003), but since 2001, droughts have been common in much of the southwestern United States, with particularly widespread and severe droughts in 2002, 2003, 2007, 2009, 2011, and 2012 (Llewellyn and Vaddey, 2013). Mean annual precipitation across the region from 1980 to 2015 was 22 to 25 percent less than the historical mean annual precipitation for the 20th century (MacDonald, 2010; Woodhouse and others, 2010; Macdonald and others, 2019).

In the water use component of the focus area study for the upper Rio Grande Basin, Ivahnenko and others (2021) discuss water use, sources of water supply, population change, and public and self-supplied household per-capita water use in the upper Rio Grande Basin. Total withdrawals for all the water use categories (including hydroelectric) in 2015, was estimated to be about 3,150 million gallons per day (Mgal/d). Nearly all withdrawals were from freshwater sources, and surface water was the dominant source of water used in the upper Rio Grande Basin, at about 71 percent of total withdrawals. Although the population in the upper Rio Grande Basin increased during the study period, groundwater withdrawals as a percentage of total municipal supply decreased from 92 percent in 1985 to 70 percent during in 2015. Although domestic deliveries from public suppliers in the upper Rio Grande Basin increased from 1985 to 1995, they have declined since 2005. The per-capita daily use for the entire upper Rio Grande Basin fluctuated between the reporting years, but overall, domestic per-capita use across the basin has declined by 46 percent from 145 gallons per capita per day (gal/cap/d) in 1985 to $78 \mathrm{gal} / \mathrm{cap} / \mathrm{d}$ in 2015 .

\section{Geologic Setting}

The Rio Grande Basin consists of a series of interconnected alluvial basins that formed in the Rio Grande rift approximately 30 million years ago (Moyer and others, 2013). The Rio Grande rift is a north-south trending structural feature that developed during a period of extension where the Earth's crust was pulled apart and faulted, creating alternating mountain ranges and basins. The Rio Grande rift extends from Colorado to Texas and includes the following noteworthy basins in the study area: San Luis, Española, Middle Rio Grande, La Jencia, Socorro, San Agustin, Jornada del Muerto, Palomas, Mesilla/Conejos-Médanos, and Tularosa-Hueco (Keller and Cather, 1994; Grauch and Connell, 2013). Basins that formed along the Rio Grande rift subsequently filled with sediments eroded from the adjacent mountain ranges, dune deposits of windblown sand, and volcanic deposits from local volcanic areas (Grauch and others, 2017, Bartolino and Cole, 2002). The resulting alluvial basins compose the Santa Fe Group aquifer system, the primary aquifer in the upper Rio Grande Basin. The Santa Fe Group aquifer system is typically divided into three parts: upper, middle, and lower. Much of the lower part tends to have low permeability and poor water chemistry; thus, groundwater is mostly withdrawn from the upper and middle parts of the aquifer system. The depths of the alluvial basins vary considerably.

The Rincon basin between Las Cruces and Truth or Consequences, N. Mex., is a subbasin within the Palomas Basin (the Rincon basin is commonly referred to as the "Rincon Valley"). The upper Rio Grande alluvial basins (fig. 1) primarily consist of Tertiary- and Quaternary-age rocks composed of gravel, sand, silt, and some clay. Some of the alluvial basins also consist of volcanic terranes. Although they are part of the Rio Grande rift, the Upper Arkansas, Mimbres, and Salt alluvial basins are outside the study area and are not discussed in this report. For this report, only the geologic units younger than Eocene Epoch are considered. 


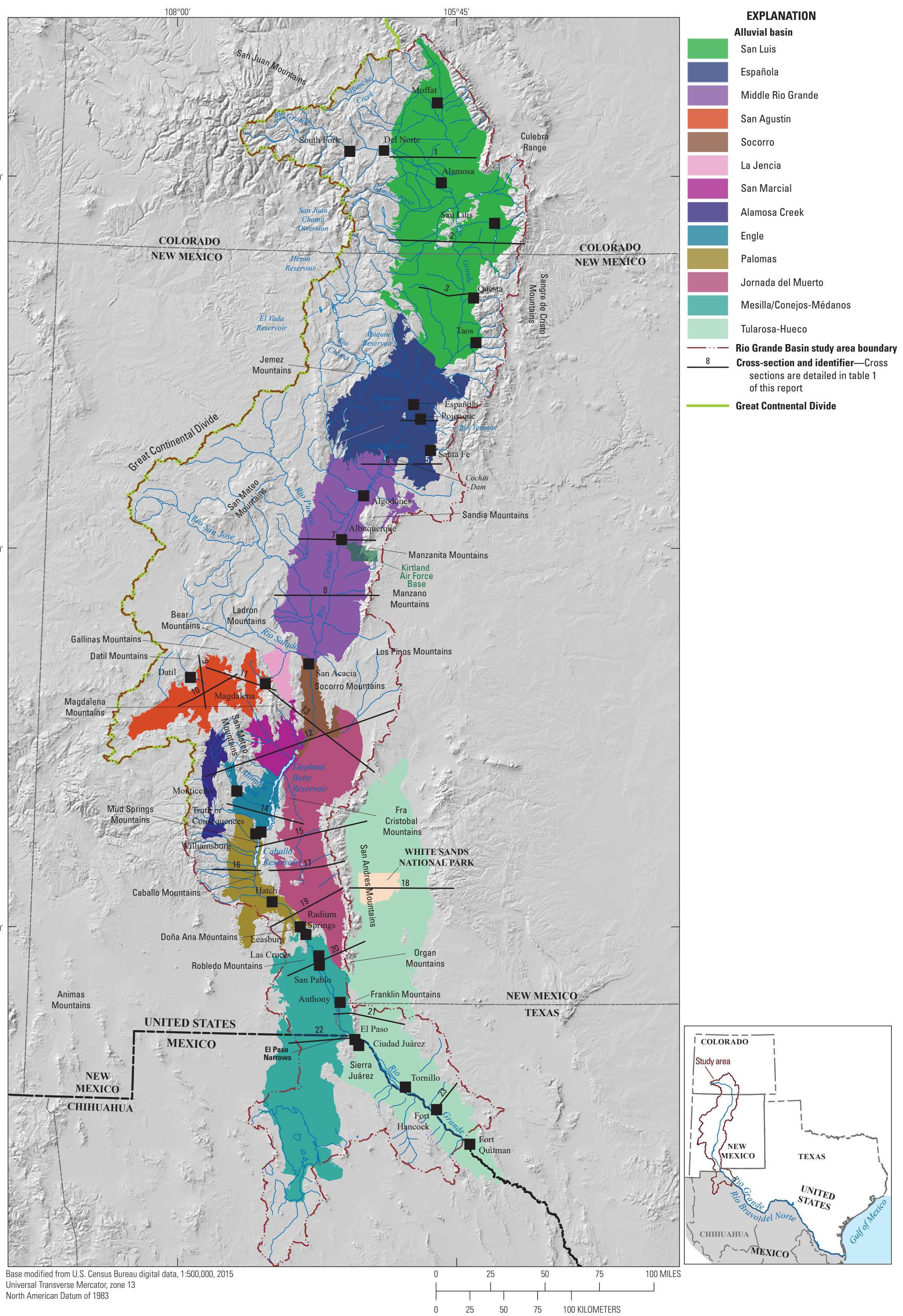

Figure 1. Map showing extent of alluvial basins and locations of selected cross-section profiles in the upper Rio Grande Basin in Colorado, New Mexico, and Texas, United States, and Chihuahua, Mexico. 


\section{Methods of Investigation}

To help improve the understanding of the hydrogeologic framework and groundwater system, readily available hydrogeologic and groundwater-level data were compiled, and a literature review of previous studies including published literature of local, State, and Federal agencies pertaining to the upper Rio Grande Basin was reviewed to obtain information that was used in this study. Data from previous USGS studies and other sources were compiled and evaluated to remove obvious recording errors or spurious values and interpreted to assess hydrogeology, quantify groundwater-level changes, and estimate groundwater storage changes.

\section{Development of Alluvial Basin Boundaries}

To evaluate the alluvial basins in the upper Rio Grande Basin, the horizontal extents of each alluvial basin boundary are needed to constrain other types of data (groundwater-level altitude and groundwater-level change maps, for example). Although there were many versions of alluvial basin boundaries in the literature, there were [as of 2020] no digital versions of all the alluvial basin boundaries delineated individually. The boundaries of the alluvial basins that were available digitally were primarily in the northern part of the basin in Colorado and New Mexico and included the San Luis, Española, and Middle Rio Grande alluvial basins. The most comprehensive study of the alluvial basins in the upper Rio Grande Basin was completed by Wilkins (1986). Detailed boundaries of the overall basins that contain the alluvial basins were not available for the following basins: San Agustin, Socorro, La Jencia, San Marcial, Alamosa Creek, Engle, Palomas, Jornada del Muerto, Mesilla/Conejos-Médanos, and Tularosa-Hueco. For this reason, only the extents of the alluvial basins are included in this report.

The literature was reviewed to obtain the existing delineations of each alluvial basin, and then those features from each delineation were converted to a digital format. Next, the literature was reviewed to identify the key features that researchers typically used to define the boundaries that separate one alluvial basin from another (faults, constrictions, mountain ranges). In the upper Rio Grande Basin, a constriction is defined as a narrowing of an area in the Rio Grande rift as a result of a deformational process, such as faulting (Chapin, 1971). Constrictions referred to in this report follow naming conventions used in previous publications, as noted during the literature review. Boundaries of the 13 alluvial basins evaluated for this study were further refined by taking into consideration alternate interpretations of alluvial basin boundary delineations identified during the literature review. More information on the data sources used to refine each of the alluvial basins can be found in the companion data release (Houston and others, 2020).

\section{Data Compilation and Refinement}

Groundwater-level measurements used to construct the groundwater-level altitude and groundwater-level change maps were acquired from data from wells in the study area (fig. 2) from existing local, State, and Federal agency data, including the Texas Water Development Board groundwater database (Texas Water Development Board, 2019a); the USGS National Water Information System (U.S. Geological Survey, 2017); the San Luis Valley well and water-level database (Davis Engineering Service, Inc., and Principia Mathematica, Inc., 2017); and the New Mexico Bureau of Geology and Mineral Resources (2020). Additional data for New Mexico were obtained from the City of Santa Fe (2020a) for the Buckman well field wells. Data for wells in Mexico were obtained from Ritchie and others (2018). Groundwaterlevel data acquired and synthesized for the study and supporting documentation are available in a companion data release (Houston and others, 2020).

The final dataset used for this report was constructed from the compiled groundwater-level data by removing well data from confined aquifers, selecting well data from only one well that was part of a group of nested wells, identifying and removing duplicate values, and identifying and removing data from wells that were not representative of the aquifer system for various reasons (Houston and others, 2020). Confined aquifers have layers of impermeable material above and below them, causing the groundwater to be under appreciably greater pressure than atmospheric pressure; as a result, the water rises above the top of the aquifer in a well that penetrates a confined aquifer (Jacob, 1940; Alley and others, 1999). Wells that were classified as confined by the data source because they were screened (completed) in the confined aquifer system and wells more than $1,500 \mathrm{ft}$ deep were removed from the final dataset. The depth of 1,500 ft was chosen as the cutoff by visually inspecting the water-level records of the nested wells. Hydrographs of water-level measurements for many of the wells deeper than $1,500 \mathrm{ft}$ indicated that the wells behaved as if they were confined wells.

There were approximately 200 nested piezometers in the study area in the San Luis, Española, Middle Rio Grande, Socorro, Palomas, Jornada del Muerto, Mesilla/ConejosMédanos, and Tularosa-Hueco alluvial basins. Piezometers are a special type of well that generally are designed to allow measurement of groundwater levels over short depth intervals within the aquifer. Piezometers screened over different intervals are often grouped within the same borehole (nested) to provide information on how groundwater-level altitudes differ with depth at a single geographic location. For nested piezometers where all the piezometers were less than $1,500 \mathrm{ft}$ deep, the deepest unconfined piezometer with the longest period of record was selected as the representative piezometer. Piezometers that were deeper than 1,500 ft and classified as unconfined were not selected to represent a given nest of piezometers; rather, the deepest piezometers in the nest that 
$\boldsymbol{A}$

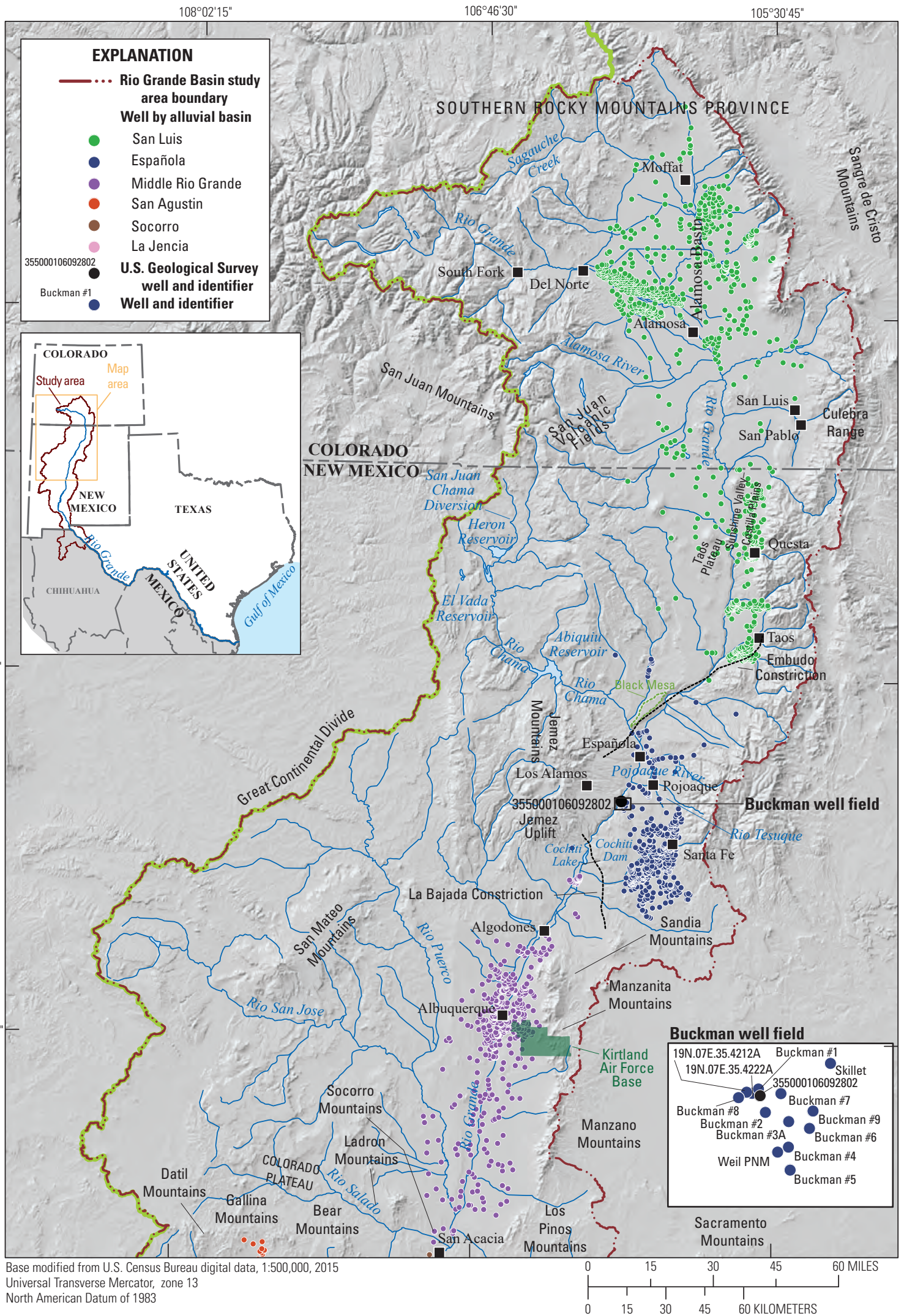

Figure 2. Maps showing wells (organized by alluvial basin) with groundwater-level measurements made from 1980 to 2015 in $A$, the northern part and $B$, the southern part of the upper Rio Grande Basin in Colorado, New Mexico, and Texas, United States, and Chihuahua, Mexico. 


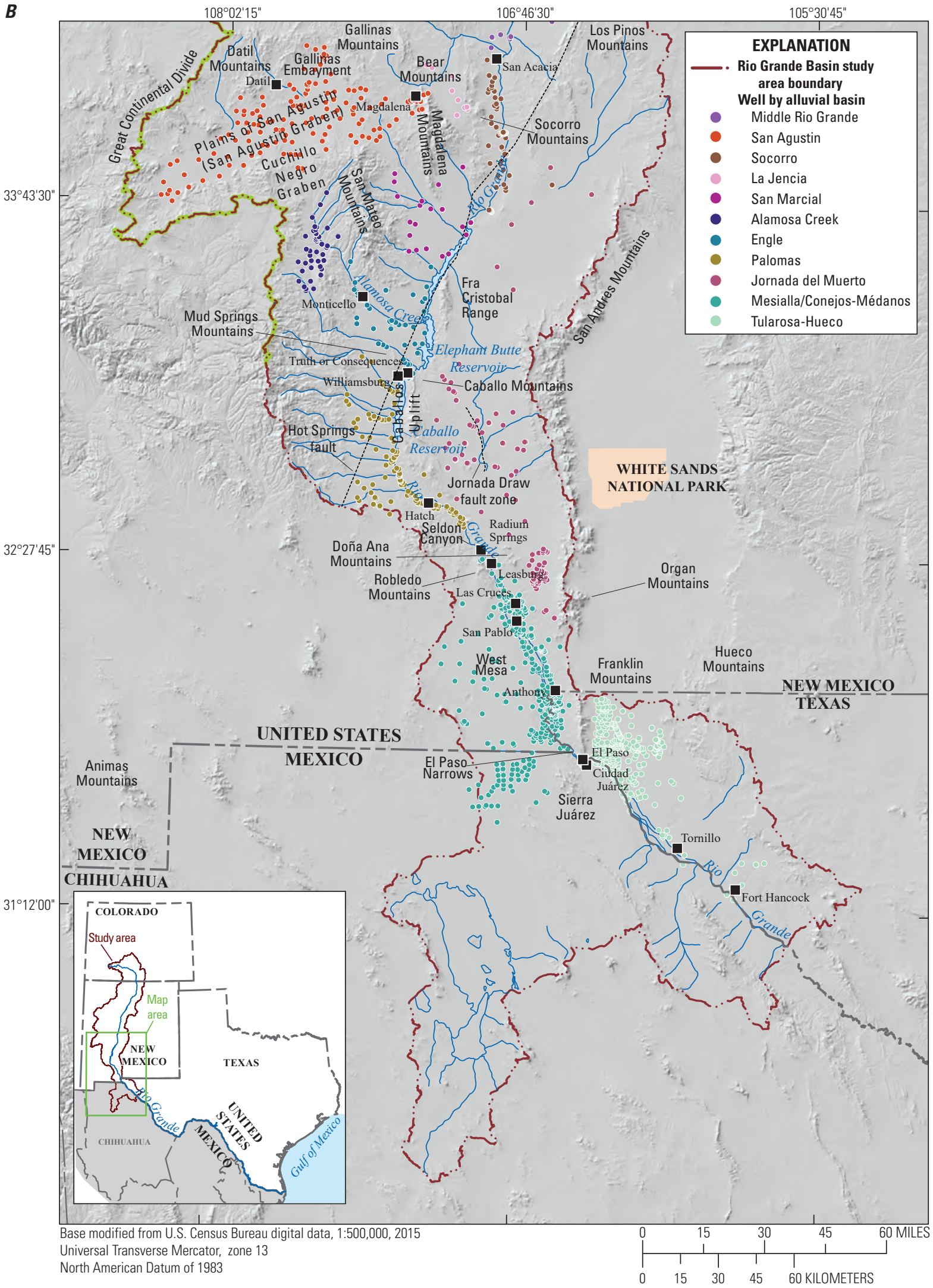

Figure 2.-Continued 
was less than $1,500 \mathrm{ft}$ deep was selected. If all the piezometers in the nest were completed to depths greater than $1,500 \mathrm{ft}$, then data from the entire nest were removed.

Groundwater-level data were checked for duplicate groundwater-level measurements by comparing measurement values, collection dates, site locations, site names, and groundwater level measurement data sources. Springs, sites without groundwater-level measurements, and groundwaterlevel measurements flagged as influenced by local or regional groundwater withdrawals were removed. Prioritization of retention for duplicate groundwater-level measurements compiled from the four source databases was as follows: USGS National Water Information System, New Mexico Bureau of Geology and Mineral Resources groundwater monitoring network, Texas Water Development Board groundwater database, and Principia Mathematica water-level database. Many of the duplicated groundwater-level measurements were a result of different agencies reporting the same data but rounding the resulting values differently. Occasionally errors were discovered where decimal locations were entered incorrectly. These groundwater-level measurements were either verified with multiple sources or removed from the analysis if the measurement could not be verified with some degree of confidence.

The resulting dataset of groundwater-level measurements was evaluated for outliers using the R-based (R Development Core Team, 2019) visGWDB program and the specialized addon packages of kernlab (Karatzoglou and others, 2016) and mgcv (Wood, 2017). The evaluation focused on visualization of time-series data and metadata for individual wells (well hydrographs) in conjunction with temporal overlap of data from nearby wells. visGWDB provides generalized additive and support vector machine models of groundwater-level altitude data for each well from nearby groundwater-level altitudes that help to evaluate the compiled groundwater-level data for potential outliers. Residuals from these models were computed, and potential outliers (residuals $4 \mathrm{ft}$ or more that also exceed the 99th percentile of the predicted standard error of fit) were identified and not used for this study. Additional information about this method is provided by Asquith and others (2019).

Groundwater-level measurements were then grouped by site in 5-year periods starting in November 1977 and ending in March 2017. The groundwater-level measurements were only from the nonirrigation season in each 12-month period when groundwater-withdrawals are at their annual minimum amounts. The nonirrigation season is from November of the year indicated through March of the following year. For the 5-year periods from 1980 through 2015, the 1980 data refer to a 5-year median of groundwater-level measurements from November 1977 through March 1982. The subsequent 5-year periods are defined in the same manner. For example, the 1985 data refer to a 5-year median of groundwater-level measurements from November 1982 through March 1987, and the 1990 data refer to a 5-year median of groundwater-level measurements from November 1987 through March 1992.

\section{Groundwater Level Analysis}

Groundwater-level altitude maps can be used to evaluate spatial and temporal groundwater-level altitude changes. Groundwater-level data were compiled for the unconfined alluvial basins within the study area and gridded as described in this section of the report to evaluate groundwater-level changes for each basin across multiple 5-year periods.

Kriging algorithms in Oasis montaj (Seequent Ltd., 2020) were used to determine the most probable value at each grid node 200-by-200-meters (m; 656-by-656-ft) based on a statistical analysis of the entire median groundwater-level altitude dataset within the active cells for each grid (Isaaks and Srivastava, 1989), where each alluvial basin is represented by a separate grid. This kriging method was chosen in part because of its utility for assessing clustered data such as the data obtained from well fields. Variance maps, automatically developed during the kriging process, were used to evaluate spatial uncertainty in the groundwater-level altitude maps. Generally, as the distance between data points becomes greater, correlation between points lessens, and uncertainty in areas between points increases (Isaaks and Srivastava, 1989). To help reduce the effects of sparsely distributed spatial and temporal data in the alluvial basins, the variance maps were used to clip (exclude beyond a certain spatial extent) the final groundwater-level altitude grids such that only those areas with an acceptable amount of uncertainty were retained, by using the processing steps listed in Houston and others (2020).

The compiled median groundwater-level altitude data for the upper Rio Grande alluvial basins were analyzed for groundwater-level changes to document and characterize changes in groundwater-level altitudes in the alluvial system. Groundwater-level altitudes in individual wells vary in response to natural and anthropogenic stresses at different timescales. The focus of the analysis was to identify spatially and temporally persistent 5 -year groundwater-level changes in the alluvial basins.

A map of groundwater-level changes for the study period was constructed to highlight areas where groundwater levels declined or rose in the upper Rio Grande alluvial basins. Median groundwater-level altitude data were plotted, and change was computed as the slope of the best-fit linearregression line of the computed 5-year median groundwaterlevel data for each well, provided that at least four 5-year periods were available (spanned at least 50-percent of the study period). Linear-regression line slopes were considered indicative of rises in groundwater-level altitudes when the slope was greater than $0.1 \mathrm{ft}$ for the given period, and declines, for slopes less than $-0.1 \mathrm{ft}$. Groundwater-level altitudes were considered essentially stable for wells with slopes of less than a $0.1-\mathrm{ft}$ rise or decline. A median linear regression slope was then computed for all the wells within each upper Rio Grande alluvial basin to help compare groundwater-level changes among basins. 


\section{Groundwater Storage Estimation Methodology}

Estimates of changes in groundwater storage (hereinafter referred to as "storage") were evaluated by using two methods. The first method used groundwater-level change maps developed to estimate changes in storage from 1980 to 2015. Changes in storage were computed for the area common to all the individual groundwater-level change maps (fig. 3). Because the available data usually resulted in different locations of groundwater level information for each 5-year time period, a continuous evaluation of storage throughout the study area was only available for a small area within each basin. Because few data values were available in some alluvial basins, estimating storage changes over time was not possible for every basin in the study area.

To estimate changes in storage based on groundwaterlevel data, groundwater-level change maps were gridded using 200-by-200-m (656-by-656-ft) cells. Groundwater-level changes sampled at the centroids of each grid cell were multiplied by the area of the cell to compute a change in volume for each cell. Cells for each basin were then summed for a total volume change during a 5-year period for each basin. These volume changes per basin were then multiplied by specific yield values which were compiled from the literature for each basin. Ranges in specific yield values were used, where available, to provide a range of storage changes over time rather than reporting one storage value estimated from a single specific yield value. Storage changes were computed for the same 5-year periods as the groundwater-level change maps. Furthermore, cumulative storage changes over time were also computed to visualize overall changes from 1980 to 2015 for most of the basins. Storage changes over time for the TularosaHueco alluvial basin were only estimated from 1980 to 2010 because few data values were collected during $2010-15$ in this basin. The second method for computing storage was based on information from previously published groundwaterflow models for the San Luis, Española, Middle Rio Grande, Mesilla/Conejos-Médanos, and Tularosa-Hueco alluvial basins (fig. 3) to determine simulated changes in storage.

Changes in storage represent the net summed values of the individual components that affect storage in an aquifer, which could include withdrawals from wells or groundwater discharge to streams that forms the base-flow component of streamflow. In all cases, simulated storage changes obtained from historical and recent groundwater-flow models were representative of more spatially extensive areas (both laterally and at depth) than storage simulated by using groundwaterlevel change maps.

\section{Limitations}

Existing information on the extent, geologic setting, groundwater-level altitudes, and storage varied spatially and temporally by alluvial basin. Groundwater-level measurements used in this study were assumed to be representative of the groundwater altitudes within the alluvial aquifers of the upper Rio Grande Basin. The temporal and spatial variance in the distribution of groundwater-level altitude measurements could be a source of measurement bias. Differences in localized conditions and stresses and differences in well construction and groundwater use could also potentially bias individual measurements. For example, the clustering of wells in a given area, an overrepresentation of wells in areas that are known to have undergone groundwater-level declines, and groundwater measurements from areas where there has been focused (intensive) monitoring are all possible sources of measurement bias.

Additional data used to assess groundwater resources such as depths of unconfined groundwater, hydraulic properties, and areas of groundwater discontinuity were more readily available in more developed alluvial basins or in areas with more groundwater use compared to less developed alluvial basins and areas where less groundwater is used. For example, the eastern and western margins of the Middle Rio Grande alluvial basin are known to be areas of groundwater discontinuity (that is, abrupt changes in groundwaterlevel altitudes) associated with a fault or fracture-dominated groundwater-flow system (Bexfield and Anderholm, 2000). Groundwater-level altitudes at individual wells in fault or fracture-dominated groundwater-flow areas were not representative of the alluvial basin as a whole and were removed from the analyses (Bexfield, 2010). Similar conditions may exist in other alluvial basins in the upper Rio Grande Basin where no additional data are available to highlight or explain potential groundwater-level altitudes that are not representative of the larger area.

Differences in geographic and temporal distribution of groundwater-level altitudes can affect the interpolated groundwater-level altitude surfaces used to compute groundwater-level and storage changes. The scarcity of spatial and temporal groundwater data coverage across the alluvial basins allowed only small parts of each alluvial basin to be evaluated for groundwater-level and storage changes, and in some alluvial basins, it was not possible to compute storage changes because of insufficient data. In all basins where storage changes were computed by using groundwater-level altitude data, the estimated changes in storage from groundwaterlevel changes were representative of smaller areas and shallower depths compared with the areas and depths of the estimated changes in storage that could be simulated by using published groundwater-flow models. 


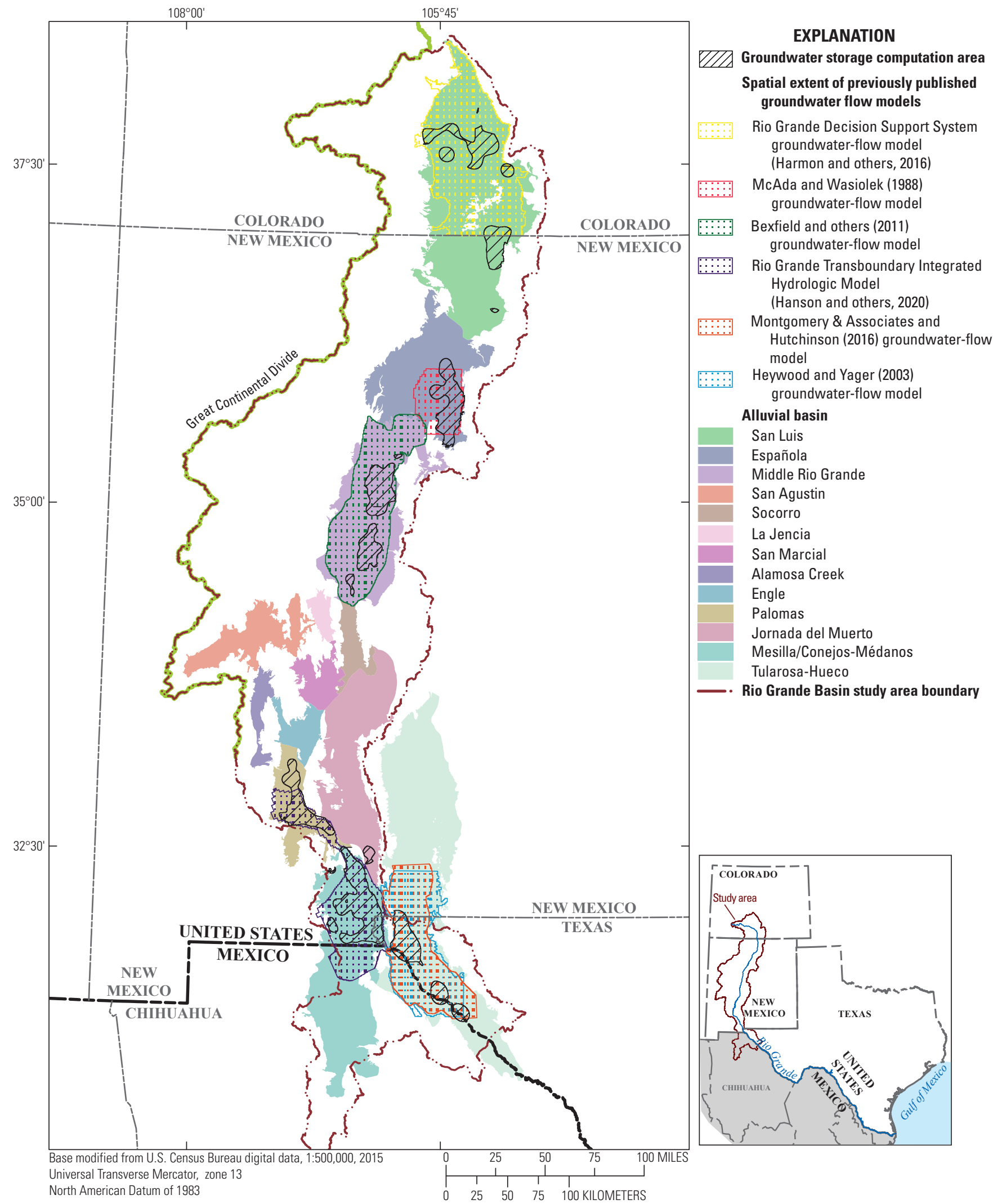

Figure 3. Map showing the spatial extent of area included in groundwater-storage computations based on groundwater levels for alluvial basins in the upper Rio Grande Basin in Colorado, New Mexico, and Texas, United States, and Chihuahua, Mexico. Also shown are active domains of groundwater-flow models from which storage changes were extracted. 


\section{Hydrogeologic Framework}

Although all 13 alluvial basins in the study area (San Luis, Española, Middle Rio Grande, Socorro, La Jencia, San Marcial, Alamosa Creek, Engle, San Agustin, Jornada del Muerto, Palomas, Mesilla/Conejos-Médanos, and TularosaHueco; listed from north to south) are part of the Rio Grande rift, each alluvial basin has a different set of challenges with respect to groundwater use and depletion. The alluvial basins contain one or more aquifers, most of which have not been delineated horizontally and vertically over their full extent. Typically, information for each basin is only available for areas with high groundwater use. This study focuses on aquifers consisting of geologic units younger than the Eocene Epoch. The spatial extents of the alluvial basins developed for this study range in size from the La Jencia alluvial basin, which covers a little more than $200 \mathrm{mi}^{2}$, to the Tularosa-Hueco alluvial basin, which covers a little more than $5,390 \mathrm{mi}^{2}$. To assist in describing the hydrogeologic framework of the upper
Rio Grande Basin in the study area, representative crosssections (fig. 1) for each of the alluvial basins were identified during the literature review (table 1).

\section{San Luis Alluvial Basin}

The San Luis alluvial basin is the northernmost alluvial basin included in the focus area study for the upper Rio Grande Basin (fig. 1). The San Luis alluvial basin is in the San Luis Valley that extends from southwestern Colorado into northern New Mexico (Bexfield and Anderholm, 2011, fig. 3). The northern part of the San Luis Valley north and east of the Rio Grande is a closed basin, and the southern part of the San Luis Valley is open, meaning that surface water flows through from one basin to the next (Wilkins, 1998). The San Luis Valley is rimmed on the west by the San Juan Mountains and on the east by the Sangre de Cristo Mountains and the Culebra Range. The San Juan volcanic field on the western side of the San Luis Valley is the subbasin where the

Table 1. Selected cross sections representing one or more alluvial basins in the upper Rio Grande Basin, in Colorado, New Mexico, Texas, and Mexico.

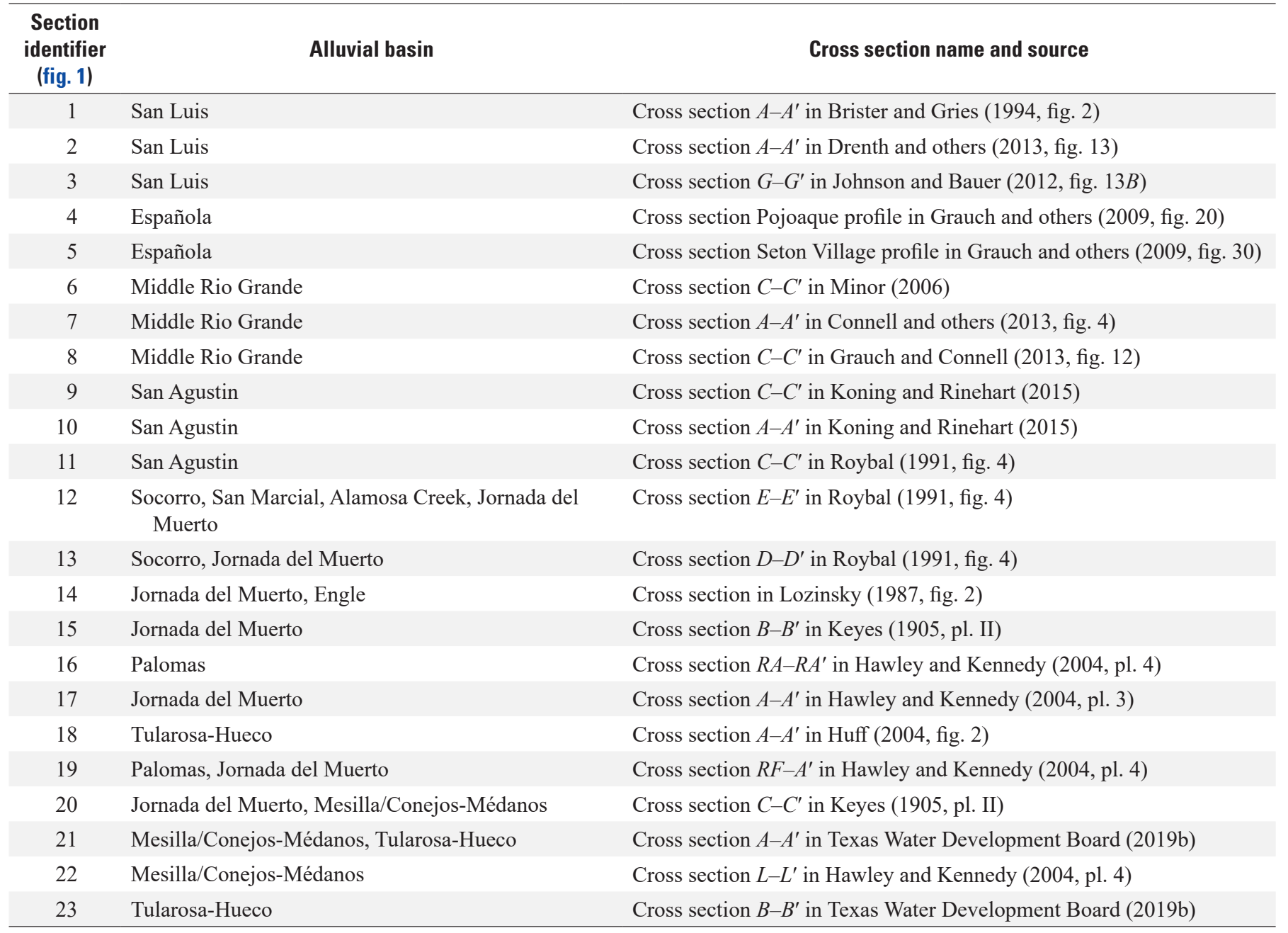


Rio Grande headwaters originate (Wilkins, 1998). There are three primary regions in the San Luis Valley: the Alamosa Valley area of Colorado, the Sunshine Valley-Costilla Plain area north of Questa, N. Mex., and the Taos Plateau in New Mexico (fig. 2A). Although detailed spatial extents for these regions have not been published to date [2021], several studies have been completed on these regions and describe their general extents (Wilkins, 1998; Thompson and McMillan, 1992; Brister and Gries, 1994; Bexfield and Anderholm, 2011; Ruleman and others, 2013). The Alamosa basin is north of the San Luis Hills in Colorado (Brister and Gries, 1994). In New Mexico, the San Luis Valley is subdivided into the Taos Plateau and Sunshine Valley-Costilla Plain areas (Bexfield and Anderholm, 2011).

The Taos Plateau is primarily underlain by volcanic deposits, lava flows, and ash; below the volcanic deposits are units of the Santa Fe Group. Thompson and McMillan (1992) state that the volcanism in the Taos Plateau volcanic field is of three distinct ages: early-rift (late Oligocene to early Miocene), postmagmatic lull (Miocene), and late-rift (Pliocene to Pleistocene).

The San Luis Valley includes metamorphic and sedimentary rocks, volcanic fields, and alluvial fill that forms the San Luis alluvial basin (fig. 1; Bexfield and Anderholm, 2011). In Colorado, the San Luis alluvial basin contains an unconfined aquifer, which includes most of the Quaternary deposits, including stream deposits, eolian sands, and alluvial fans. Within the San Luis Valley, the shallow unconfined groundwater is at 50 to $200 \mathrm{ft}$ beneath the land surface and is underlain by a local confining unit that consists of clay layers in the upper part of the Alamosa Formation (Sangre de Cristo National Heritage Area, 2019). The confined aquifer consists of the lower part of the Alamosa Formation of both Pleistocene (Quaternary) and Pliocene (Tertiary) age and the Vallejo and Santa Fe Formations of Pliocene and Miocene (Tertiary) age.

In New Mexico, the San Luis alluvial basin contains a shallow basin fill aquifer consisting of Quaternary alluvium and the Servilleta Basalt and a deeper basin fill aquifer consisting of the Chamita Formation and the Tesuque Formation of the Santa Fe Group (Johnson and Bauer, 2012). The Tesuque Formation composes the primary aquifer in the basin that has two distinct parts: an upper part, which is unconfined and as much as $800 \mathrm{ft}$ thick, and a confined part, which is as much as 1,200 ft thick (McAda and Wasiolek, 1988).

The San Luis alluvial basin is the second largest alluvial basin in the study area and covers approximately 4,980 $\mathrm{mi}^{2}$ in the northern part of the upper Rio Grande Basin. The San Luis alluvial basin includes the highest peaks, highest median land-surface altitude, and largest range in topography of all the alluvial basins. Within the alluvial basin the median landsurface altitude is about $7,670 \mathrm{ft}$ above NAVD 88 , and landsurface altitudes range from about 5,870 to nearly $12,600 \mathrm{ft}$ above NAVD 88.

\section{Española Alluvial Basin}

The Española alluvial basin (fig. 1) is in the Española Basin in northern New Mexico (Grauch and others, 2009, fig. 1). The Española Basin is connected to the San Luis Valley to the north at the Embudo constriction and connected to the Middle Rio Grande Basin to the south at the La Bajada constriction (Kelley, 1952). The Española Basin is rimmed on the east by the Sangre de Cristo Mountains (Wilkins, 1986). The Española Basin contains volcanic fields, sedimentary rocks, intrusive and extrusive rocks, Precambrian rocks, and the Española alluvial basin (Johnson and others, 2013, fig. 1). The Jemez volcanic field is included in the depiction of the Española alluvial basin (fig. 1) because it was deposited when the alluvial basin was being filled and because it is underlain by thick alluvial deposits.

The primary geologic units in the Española alluvial basin are the Tesuque, Puye, and Ancha Formations of the Santa Fe Group. The primary aquifer in the alluvial basin is composed of the Tesuque Formation (McAda and Wasiolek, 1988). The Española alluvial basin is approximately $2,350 \mathrm{mi}^{2}$ and has the second highest topographic relief of the 13 alluvial basins in this study where land-surface altitudes in the Española alluvial basin range from about 5,330 to $11,570 \mathrm{ft}$ above NAVD 88 and has the third highest median land-surface altitude, at about $6,870 \mathrm{ft}$ above NAVD 88 . Santa Fe is the largest city in the basin and since 1972 has maintained a well field in the Española alluvial basin, near Buckman, N. Mex., for municipal use.

The Buckman well field historically was suspected of causing streamflow depletion in the Rio Grande and in selected tributaries to the Rio Grande, namely the Pojoaque River and Rio Tesuque (McAda and Wasiolek, 1988). Beginning in the mid-1980s, researchers began studying the link between groundwater withdrawals from the Buckman well field and reduced streamflow in the Rio Grande. According to McAda and Wasiolek (1988), 23,700 acre-feet (ac-ft; 29.2 million cubic meters $\left[\mathrm{Mm}^{3}\right]$ ) of groundwater was withdrawn from the Buckman well field from 1972 through 1986. Although the City of Santa Fe currently [2021] is permitted to annually withdraw 10,000 acre-feet per year (ac-ft/yr; 12.3 million cubic meters per year $\left[\mathrm{Mm}^{3} / \mathrm{yr}\right]$ ) of groundwater from the Buckman well field, in the past 6 years, pumping under permit has been less than 1,000 ac-ft/yr $\left(1.23 \mathrm{Mm}^{3} / \mathrm{yr}\right.$; City of Santa Fe, 2020b). To assess the effects of groundwater withdrawals in this area, a monitoring program is in place, and several agencies, including the USGS and the City of Santa Fe, monitor groundwater-level altitudes. In May 2011, the City of Santa Fe began direct diversion of water from the Rio Grande under the Bureau of Reclamation's San Juan-Chama Project to help reduce reliance on groundwater for municipal supply (Glaser, 2011). Within the basin, a coordinated water conservation strategy has also reduced per capita water use in Santa Fe by approximately 30 percent since 1995 (Chavez, 2020). 


\section{Middle Rio Grande Alluvial Basin}

The Middle Rio Grande alluvial basin (fig. 1) is in the Middle Rio Grande Basin in northern New Mexico (Grauch and Connell, 2013, fig. 1). The Middle Rio Grande Basin includes Albuquerque and is sometimes referred to as the Albuquerque basin (Connell and others, 2013; Grauch and Connell, 2013). The Middle Rio Grande Basin is rimmed to the north by the Española Basin and the Jemez Mountains and to the east by the Sandia, Manzanita, Manzano, and Los Pinos Mountains. The constriction at San Acacia, N. Mex., is the southern boundary of the Middle Rio Grande Basin (Wilkins, 1986). The Middle Rio Grande Basin includes carbonate rocks, evaporite rocks, metamorphic rocks, sedimentary rocks, volcanic rocks, and the Middle Rio Grande alluvial basin (Bexfield, 2010, fig. 1). The hydrology of the Middle Rio Grande alluvial basin is complex because of faulting and the heterogeneous composition of different sediment deposits in the basin, the combination of which result in large variances in hydraulic properties (Bartolino and Cole, 2002). Multiple studies have identified and mapped fault zones that run parallel to the Middle Rio Grande alluvial basin along the basin's east and west margins (Bexfield and Anderholm, 2000; Connell and others, 2013; Grauch and Connell, 2013).

The Middle Rio Grande alluvial basin extends from the Cochiti Dam to San Acacia and covers approximately $3,020 \mathrm{mi}^{2}$. The Middle Rio Grande alluvial basin is not only one of the larger basins in the upper Rio Grande Basin but also one of the deepest, with thicknesses of basin-fill deposits in the Santa Fe Group ranging from about 1,400 $\mathrm{ft}$ at the basin margins to approximately $14,000 \mathrm{ft}$ in the deepest parts of the Middle Rio Grande alluvial basin (Bartolino and Cole, 2002). The basin has the sixth highest median land-surface altitude (5,360 ft above NAVD 88) among the 13 alluvial basins that compose the study area and ranges from about 4,670 to $7,840 \mathrm{ft}$ above NAVD 88.

Groundwater in the basin is primarily unconfined and semiconfined. There are some areas of the basin that are locally confined systems, such as the area around Kirtland Air Force Base (fig. 2A). Predevelopment groundwater flow (before 1961) from north to south through the basin and from east to west along the mountain front (Bexfield, 2010) has been modified by intensive groundwater withdrawals used for municipal supply. Albuquerque, the largest city in the Middle Rio Grande alluvial basin, historically obtained its municipal water supply from groundwater in the Santa Fe Group aquifer system. By the 1990s, it was determined that withdrawals from the Santa Fe Group aquifer system near Albuquerque were depleting groundwater in storage and capturing water from the Rio Grande (Kernodle and others, 1995). Following these studies, Albuquerque revised its water-use strategy to actively encourage water-use conservation and move toward the direct use of native Rio Grande water and water diverted from the
San Juan River by the San Juan-Chama Project (Bartolino and Cole, 2002); direct diversion of surface water for municipal supply started in December 2008 (Bexfield, 2010).

\section{San Agustin Alluvial Basin}

The San Agustin alluvial basin (fig. 1) is in the San Agustin Basin in New Mexico (Myers and others, 1994, fig. 1). The San Agustin Basin is a closed basin and does not drain to the Rio Grande (Basabilvazo, 1997). The San Agustin Basin is bounded to the north by the Datil and Gallinas Mountains, to the south and west by the Great Continental Divide, and to the east by the Gallinas and San Mateo Mountains (Myers and others, 1994, fig. 1). Groundwater in the plains of San Agustin in the part of the San Agustin alluvial basin west of the Gallinas Mountains is unconfined (Basabilvazo, 1997). The San Agustin Basin includes both prerift volcanic deposits and the San Agustin alluvial basin (fig. 1). The San Agustin alluvial basin covers approximately $1,010 \mathrm{mi}^{2}$, has the second highest median land-surface altitude of the 13 alluvial basins described in this report at about $7,000 \mathrm{ft}$ above NAVD 88 , and ranges from about 6,030 to $8,000 \mathrm{ft}$ above NAVD 88.

Groundwater in the San Agustin alluvial basin is used primarily for agriculture, livestock, and municipal supply, primarily by Magdalena and Datil, N. Mex. Groundwater withdrawals by the Village of Magdalena are from the alluvial sediments and from fractured bedrock (Timmons, 2013). As a result of a sustained drought in the study area in 2012 and 2013, the Village of Magdalena's main production well went dry. In response, the New Mexico Bureau of Geology and Mineral Resources collected groundwater-level measurements from 37 wells and compared the groundwater-level measurements to values reported when the wells were drilled (if available) and to a previous study by Summers (1975). Recharge to the aquifers in the San Agustin alluvial basin near Magdalena is primarily from precipitation (Timmons, 2013). Decreased precipitation and increased withdrawals have caused groundwater-level altitudes to decline by as much as $100 \mathrm{ft}$ in some locations. Local groundwater-level maps developed for the Timmons (2013) study show the local groundwater flow as north toward the Village of Magdalena and then to the east, which deviates from the regional flow direction of the San Agustin alluvial basin.

Concerns over water supply near Datil began in 2008 when a local rancher applied for a permit to drill 37 wells and export as much as $54,000 \mathrm{ac}-\mathrm{ft}\left(66.6 \mathrm{Mm}^{3}\right)$ of groundwater to Albuquerque. Residents and ranchers were concerned the export would dry up their water supply (Utton Transboundary Resources Center, 2015). To date [2021], the permit to pump and export groundwater has been denied by the New Mexico Office of the State Engineer (Bravo, 2018; Turner, 2019). 


\section{Socorro Alluvial Basin}

The Socorro alluvial basin is in the Socorro Basin in central New Mexico. The Socorro Basin is connected to the north with the Middle Rio Grande Basin and to the south with the San Marcial and the Jornada del Muerto Basins (Wilkins, 1986). A detailed map of the extent of the Socorro Basin has not been published to date [2021]. The Socorro Basin includes volcanic rocks, sedimentary rocks, and fill associated with the Socorro alluvial basin (fig. 1; Newton, 2004). The major geologic units in the Socorro alluvial basin include Quaternary alluvium and the Sierra Ladrones and Popotosa Formations of the Santa Fe Group. The Quaternary alluvium and Sierra Ladrones Formation compose a shallow aquifer. The upper part of the Popotosa Formation is considered a confining unit, and the lower part of the Popotosa Formation is locally referred to as the Popotosa aquifer (Anderholm, 1983; S.S. Papadopulos \& Associates, Inc., 2002). According to Anderholm (1983, p. 308), "on a local scale in the irrigated part of the river valley, groundwater flow is dominated by the river, conveyance channels, laterals, and drains." The Socorro alluvial basin is the third smallest alluvial basin in the upper Rio Grande Basin, covering a little more than $390 \mathrm{mi}^{2}$ in the central part of the basin. With land-surface altitudes ranging from about 4,460 to $5,710 \mathrm{ft}$ above NAVD 88 , the Socorro alluvial basin has the smallest amount of topographic relief in the alluvial basins and a median land-surface altitude of about $4,810 \mathrm{ft}$ above NAVD 88.

\section{La Jencia Alluvial Basin}

The La Jencia alluvial basin is part of the La Jencia Basin in central New Mexico. The La Jencia Basin is bounded on the east and separated from the Socorro Basin by the Socorro Mountains, on the west by the Bear and Magdalena Mountains, on the south by the Magdalena Mountains, and on the north by the Colorado Plateau and the Ladron Mountains (Anderholm, 1987). A detailed map of the extent of the La Jencia Basin has not been published to date [2021]. The La Jencia Basin is east of Magdalena and defines where the Rio Grande rift system broadens into a series of parallel basins separated by intrarift horst blocks (Chapin, 1971; Land, 2016).

The major aquifer system in the Socorro alluvial basin extends west to the La Jencia alluvial basin and consists of a shallow aquifer that includes the Quaternary alluvium and the Sierra Ladrones Formation of the Santa Fe Group and a deep aquifer consisting of the Popotosa Formation of the Santa Fe Group (Anderholm, 1983; S.S. Papadopulos \& Associates, Inc., 2002). Anderholm (1987) discussed how limestone, dolomite, and gypsum substantially affect the groundwater quality and how sandstones, conglomerates, and limestones (where fractured) also act as aquifers in the basin. The La Jencia Basin includes minor amounts of volcanic and sedimentary rocks in addition to La Jencia alluvial basin (fig. 1; Anderholm, 1983). As the smallest alluvial basin in the upper
Rio Grande Basin, the La Jencia alluvial basin covers a little more than $200 \mathrm{mi}^{2}$ in the central part of the upper Rio Grande Basin. The median land-surface altitude in the La Jencia alluvial basin of about $5,900 \mathrm{ft}$ above NAVD 88 is the fifth highest in the alluvial basins, and land-surface altitudes range from about 5,130 to $8,310 \mathrm{ft}$ above NAVD 88 .

\section{San Marcial Alluvial Basin}

The San Marcial alluvial basin is in the San Marcial Basin and is in central New Mexico. The main axis of the San Marcial Basin trends from northwest to southeast and coincides with the Rio Grande. The San Marcial Basin is linked axially to the Engle Basin to the south, the Socorro Basin to the north, and Jornada del Muerto Basin to the east and is bounded to the west by the Magdalena and San Mateo Mountains, to the southeast by the constriction of the Fra Cristobal Mountains, and to the southwest by the San Mateo Mountains (Wilkins, 1986). A detailed map of the extent of the San Marcial Basin has not been published to date [2021]. The San Marcial Basin includes Tertiary volcanic rocks and the San Marcial alluvial basin (fig. 1; Kelley, 1952). Although the San Marcial alluvial basin covers approximately $470 \mathrm{mi}^{2}$, there is minimal development in the alluvial basin and relatively little detailed hydrogeologic information. Land-surface altitudes in the San Marcial alluvial basin range from about 4,420 to 7,400 $\mathrm{ft}$ above NAVD 88 , and the alluvial basin has the seventh highest median land-surface altitude in the upper Rio Grande Basin at about 5,250 ft above NAVD 88.

\section{Alamosa Creek Alluvial Basin}

The Alamosa Creek alluvial basin (fig. 1) is in the Alamosa Creek Basin in west-central New Mexico (Myers and others, 1994, fig. 1). The Alamosa Creek Basin is bounded to the northwest by the San Agustin Basin, to the northeast by the San Mateo Mountains, and to the southwest by the Great Continental Divide (Myers and others, 1994). The Alamosa Creek Basin includes volcanic rocks, pre-Tertiary sedimentary rocks, and the Alamosa Creek alluvial basin (fig. 1; Myers and others, 1994). The Alamosa Creek alluvial basin is the second smallest alluvial basin discussed in this report; it covers a little less than $300 \mathrm{mi}^{2}$ along the western side of the upper Rio Grande Basin. The Alamosa Creek alluvial basin has the fourth highest median land-surface altitude at about $6,730 \mathrm{ft}$ above NAVD 88, and the topography ranges from about 5,310 to $7,910 \mathrm{ft}$ above NAVD 88 .

\section{Engle Alluvial Basin}

The Engle alluvial basin is in the Engle Basin in southcentral New Mexico. It is considered a half graben that is axially linked to the San Marcial Basin of the southern Rio Grande rift system, and together, these two basins connect 
the Socorro Basin with the Palomas Basin (Connell and others, 2013; Land, 2016). A detailed map of the extent of the Engle Basin has not been published to date [2021]. The Engle Basin includes volcanic rocks and the Engle alluvial basin (fig. 1). The Engle alluvial basin is thickest in depth on the eastern extent, along the Hot Springs fault, where the thickness of the fill material is believed to be more than $2,300 \mathrm{ft}$ thick (Lozinsky, 1987). The Engle alluvial basin covers a little more than $410 \mathrm{mi}^{2}$ and contains the Elephant Butte Reservoir. Truth or Consequences, N. Mex., is the largest city in the Engle alluvial basin and is about $12 \mathrm{mi}$ south of the Elephant Butte Reservoir, which coincides with the southern part of the Socorro Basin. Within the Engle alluvial basin, land-surface altitudes range from about 4,230 to 7,840 ft above NAVD 88, and the alluvial basin has the eighth highest median landsurface altitude of the alluvial basins in the upper Rio Grande Basin at about 4,930 ft above NAVD 88.

\section{Palomas Alluvial Basin}

The Palomas alluvial basin is in the Palomas Basin in south-central New Mexico. The Palomas Basin is connected to the Engle Basin on the northern side by a structural trough west of the Mud Spring Mountains (Kelley, 1952, pl. 1, p. 99). The Palomas Basin is constrained on the east by the Caballo Mountains, to the south by a constriction near Radium Springs, and to the west by downfaulted Precambrian units (Wilkins, 1986). The Palomas Basin includes Tertiary volcanic and intrusive rocks, Paleozoic rocks, and the Palomas alluvial basin (fig. 1; Kelley, 1952). Along the eastern side of the Palomas alluvial basin, fill consists of mostly poorly sorted, coarse- to fine-grained sand with minor silt and clay interbeds and reaches depths greater than 6,500 ft (Lozinsky, 1987). A detailed map of the extent of the Palomas Basin has not been published to date [2021]. Covering approximately $890 \mathrm{mi}^{2}$ in the central part of the study area, the Palomas alluvial basin is the eighth largest alluvial basin in the upper Rio Grande Basin. The Palomas alluvial basin has the second lowest amount of topographic relief, and with groundwater-level altitudes ranging from about 3,970 to 5,660 ft above NAVD 88, has the third lowest median land-surface altitude in the alluvial basins at about 4,560 $\mathrm{ft}$ above NAVD 88. Hatch is the largest city in the Palomas alluvial basin and coincides with an area of intense agriculture use along the Rio Grande.

\section{Jornada del Muerto Alluvial Basin}

The Jornada del Muerto alluvial basin (fig. 1) is in the Jornada del Muerto Basin in south-central New Mexico (Sheng, 2013, fig. 1). It is bounded by the Caballo and Fra Cristobal Mountains to the west and the San Andres Mountains to the east. Located in an extension-dominated terrace, this basin is unique among the alluvial basins of the upper Rio Grande Basin, exhibiting minimal faulting and extension (Lozinsky, 1987). Because of the eastward tilting of the Caballo uplift and westward tilting of San Andres uplift, the north-south trending Jornada del Muerto alluvial basin is structurally a syncline (trough) that plunges to the south-southeast (Seager, 2005; Newton and others, 2015). The Jornada Draw fault zone, which runs approximately parallel to the syncline from north to south with downthrow to the east, substantially affects the groundwater system by creating groundwater divides in some areas and connecting erosional features in others (Newton and other, 2015). Hydraulic conductivity is highly variable because the lithology primarily consists of sandstones, siltstones, and conglomerates, which have resulted in erosional features as less-resistant rocks eroded (Newton and others, 2015). The Jornada del Muerto Basin includes volcanic deposits, Paleozoic and Triassic sedimentary rocks, and the Jornada del Muerto alluvial basin (fig. 1). Kelley (1952, p. 6) states that "the sub-alluvial bench of Santa Fe Group sediments probably does not connect with deep Pliocene basins in the Jornada del Muerto Basin." The Jornada del Muerto alluvial basin extends more than $2,250 \mathrm{mi}^{2}$. Land-surface altitudes in the Jornada del Muerto alluvial basin range from about 4,080 to $6,430 \mathrm{ft}$ above NAVD 88, and the basin has the fourth lowest median landsurface altitude at about 4,750 ft above NAVD 88.

\section{Mesilla/Conejos-Médanos Alluvial Basin}

The Mesilla/Conejos-Médanos alluvial basin (fig. 1) is in the Mesilla/Conejos-Médanos Basin in south-central New Mexico and far western Texas and extends south into Mexico (Sheng, 2013, fig. 1). The Mesilla/Conejos-Médanos Basin is bounded on the east by the Organ, Franklin, and Juárez Mountains and to the north by the Robledo and Doña Ana Mountains (Wilkins, 1998; Hawley and others, 2001; Sheng, 2013). The Mesilla/Conejos-Médanos Basin is linked to the north with the Palomas Basin and to the east with the Jornada del Muerto Basin. The units of the Santa Fe Group, including the Camp Rice Formation, Rincon Valley Formation, and the Hayner Ranch Formation, make up the principal aquifer system in the Mesilla/Conejos-Médanos Basin and separate the Santa Fe Group into upper, middle, and lower parts of the Santa Fe aquifer, respectively (Sweetkind, 2017; Teeple, 2017).

The Mesilla/Conejos-Médanos Basin is an open basin, and the Rio Grande passes through from Selden Canyon near Radium Springs to the El Paso Narrows (Wilkins, 1998). The Mesilla/Conejos-Médanos Basin includes exposed bedrock formations of the mountain ranges, uplifted areas from volcanic activity, and the Mesilla/Conejos-Médanos alluvial basin (fig. 1; Hoffer, 1976). The Mesilla/Conejos-Médanos alluvial basin is the third largest alluvial basin the upper Rio Grande Basin, covering nearly $3,150 \mathrm{mi}^{2}$. Although it is one of the largest basins in the upper Rio Grande Basin, it has the fourth smallest topographic relief, with land-surface altitudes ranging from about 3,720 to 5,790 ft above NAVD 88. The Mesilla/ Conejos-Médanos alluvial basin has the lowest median land-surface altitude in the upper Rio Grande Basin at about 4,020 ft above NAVD 88 . 


\section{Tularosa-Hueco Alluvial Basin}

The Tularosa-Hueco alluvial basin (fig. 1) is in the Tularosa-Hueco Basin in the southern part of the upper Rio Grande Basin in southern New Mexico and far western Texas and extends southwest into Mexico (Sheng, 2013, fig. 1). The Tularosa-Hueco Basin also includes White Sands National Park, a gypsum sand dune field. The Tularosa-Hueco Basin includes igneous rocks of Precambrian age, sedimentary rocks, and the Tularosa-Hueco alluvial basin (fig. 1; Heywood and Yager, 2003; Huff, 2004). The Texas Water Development Board defines the aquifer contained within the Mesilla/Conejos-Médanos and Tularosa-Hueco Basins as the Hueco-Mesilla Bolsons aquifer (Texas Water Development Board, 2019b). Although defined as a single major aquifer in Texas, the Tularosa-Hueco alluvial basin and Mesilla/ConejosMédanos alluvial basin are structurally separate basins.

In published reports, the Tularosa and Hueco basins are generally split arbitrarily about $7 \mathrm{mi}$ north of the Texas border into two basins (with the Tularosa basin to the north and the Hueco basin to the south), although there are no structural or groundwater divides that define a boundary between these two basins (Wilkins, 1986). For this study, the Tularosa and Hueco alluvial basins are defined as one alluvial basin; however, only the Hueco part of the alluvial basin is within the upper Rio Grande Basin study area, and the discussion about groundwater-level altitudes and storage is focused on the Hueco alluvial basin. The major geologic units in the Hueco alluvial basin include Quaternary alluvium and the Camp Rice and Fort Hancock Formations of the Santa Fe Group. These geologic units compose the principal aquifer system in the basin (Heywood and Yager, 2003; Petrossian and others, 2017). Although the Tularosa-Hueco alluvial basin is the largest alluvial basin of the 13 alluvial basins in this study at a little more than $5,390 \mathrm{mi}^{2}$, only the Hueco part of the alluvial basin is in the upper Rio Grande Basin, and its area is about $2,390 \mathrm{mi}^{2}$. At about $4,030 \mathrm{ft}$ above NAVD 88 , the Tularosa-Hueco alluvial basin has the second lowest median land-surface altitude in the upper Rio Grande Basin. Landsurface altitudes range from a high of $6,070 \mathrm{ft}$ to the lowest land-surface altitude in the upper Rio Grande Basin at about $2,120 \mathrm{ft}$ above NAVD 88 .

\section{Groundwater Level and Estimated Groundwater Storage Change Analysis}

Of the 2,699 wells with groundwater-level altitude data used in this study, there were 1,055 wells with data for only a single 5 -year period during the study period, 703 wells with data for 50 percent or more of the 5 -year periods during the study period, and only 57 wells with data for all 5 -year periods during the study period (Houston and others, 2020). The temporal and geographic distribution of groundwater-level measurements potentially introduces bias, limiting the analysis to areas or well clusters that were known to have recorded groundwater-level declines and where there has been focused monitoring.

The median slope of groundwater-level altitudes (the linear regression line of the 5-year median groundwater-level altitudes) was computed to help evaluate groundwater-level changes from 1980 to 2015 (table 2). The median slope (median of all linear regression slopes computed for all wells with 50 percent or more of the 5-year periods represented by the years from 1980 to 2015) for the upper Rio Grande Basin was a decline of $0.13 \mathrm{ft}$ per 5 -year period; declines were measured in 53 percent of the 703 wells. Computed median slopes indicating declines in groundwater-level altitudes of 1.00 to $1.99 \mathrm{ft}$ per 5 -year period were measured in 17 percent of the wells, of 2.00 to $2.99 \mathrm{ft}$ per 5 -year period in 3 percent of the wells, and of more than $3.00 \mathrm{ft}$ per 5 -year period in 1 percent of the wells (Houston and others, 2020). Overall, groundwater levels rose in 6 percent of the 703 wells that contained data

Table 2. Median slope of 5-year median groundwater-level altitudes for alluvial basins in the upper Rio Grande Basin in Colorado, New Mexico, and Texas, United States, and in Mexico, from 1980 to 2015.

[Groundwater-level measurements were grouped by site for each alluvial basin in 5-year periods starting in November 1977 and ending in March 2017; the groundwater-level measurements were only from the nonirrigation season in each 12-month period when groundwater-withdrawals are at their annual minimum amounts. The nonirrigation season is from November of the preceding year through March of the following year. For the 5-year periods from 1980 through 2015, 1980 refers to a 5-year median of groundwater-level measurements from November 1977 through March 1982; the subsequent 5-year periods are defined in the same manner. The number of wells is for wells where groundwater-level measurements were collected during 50 percent or more of the study period. The median slope is the median linear regression slope in feet (ft) per 5-year period for the best-fit linear regression lines for 5-year median groundwater levels at sites with groundwater-level measurements in 50 percent or more of the 5-year periods from 1980 to 2015; negative median slope values indicate a decline in groundwater-level altitude (that is, an increase in depth to groundwater) over the study period. - , insufficient data]

\begin{tabular}{lcc}
\hline \multicolumn{1}{c}{ Alluvial basin } & Number of wells & Median slope (ft) \\
\hline San Luis & 55 & 0.01 \\
Española & 66 & -0.17 \\
Middle Rio Grande & 131 & -0.01 \\
San Agustin & 23 & -0.03 \\
Socorro & 10 & - \\
La Jencia & - & - \\
San Marcial & 4 & - \\
Alamosa Creek & 2 & - \\
Engle & 7 & - \\
Palomas & 61 & -0.10 \\
Jornada del Muerto & 21 & -0.01 \\
Mesilla/Conejos-Médanos & 169 & -0.10 \\
Tularosa-Hueco & 154 & -1.09 \\
\hline
\end{tabular}


for 50 percent or more of the study period, and in 4 percent of the wells, groundwater levels rose by $1 \mathrm{ft}$ or more per 5 -year period (Houston and others, 2020). The slope of groundwaterlevel change for any single well may not represent conditions for the entire alluvial basin, but the general pattern of groundwater-level declines or rises in multiple wells may help illustrate persistent patterns in the upper Rio Grande Basin.

The San Luis, Española, Middle Rio Grande, and Palomas alluvial basins each had seven wells with groundwater-level data for the study period. In the Mesilla/ Conejos-Médanos and Tularosa-Hueco alluvial basins, there were 25 and 4 wells, respectively, with groundwater-level data for each 5-year period from 1980 to 2015 . Of the 57 wells with groundwater-level data for the entire study period, only 24 were completed in the Santa Fe Group in New Mexico and Colorado or its equivalent in Texas and Mexico; the remaining 33 wells were completed in the alluvium or basin-fill deposits. The 33 wells completed in the alluvium or basin-fill deposits at depths of less than $150 \mathrm{ft}$ exhibited numerous fluctuations (rises and declines) in groundwater-level altitudes during the study period. Compared with the fluctuating groundwaterlevel altitudes in the 33 wells completed in the shallower alluvium or basin-fill deposits, the groundwater-level altitudes in remaining 24 wells completed in the Santa Fe Group at depths of more than $150 \mathrm{ft}$ did not fluctuate appreciably but instead tended to steadily decline during the study period.

Because there were few groundwater-level data spanning the entire study period, grid-to-grid comparisons were used to assess groundwater-level changes between the 5-year periods. Using grid-to-grid comparisons may lead to high variance in areas of low data density where data are not temporally available for the entire period. This, in part, is why variance grids were used to clip the data and why groundwater-level change maps were developed only for areas that had acceptable variance values for each 5-year period used in a grid-togrid comparison (Houston and others, 2020). The minimum, median, and maximum groundwater-level changes by alluvial basin (table 3) were computed from actual groundwater-level measurements as opposed to median slopes derived from the linear regression of median 5-year groundwater-level altitudes.

Maps depicting the median 5-year groundwater-level altitudes from 1980 to 2015 were prepared for the upper Rio Grande Basin (figs. 4-11). For the 5-year periods from 1980 through 2015, 1980 refers to a 5-year median of groundwater-level measurements from November 1977 through March 1982; 1985 refers to a 5-year median of groundwater-level measurements from November 1982 through March 1987 ("Data Compilation and Refinement" section of this report). The subsequent 5-year periods are defined in the same manner. In addition to the median groundwater-level altitude maps prepared at 5-year intervals, median groundwater-level change maps were also prepared for the overall study period (fig. 12). The process outlined in the "Data Compilation and Refinement" section of this report was used to minimize the effects that changes in the spatial distribution of groundwater-level data could have on the groundwater-level altitude and groundwater-level change maps. Differences between median groundwater-level altitude maps were then assessed to determine median groundwaterlevel altitude changes between each 5-year period from 1980 to 2015 .

\section{San Luis Alluvial Basin}

There are three primary regions in the San Luis Valley that use groundwater obtained from the San Luis alluvial basin: the Alamosa Valley area of Colorado, the Sunshine Valley-Costilla Plain area north of Questa, N. Mex., and the Taos Plateau in New Mexico (fig. 2A). The Rio Grande Water Conservation District monitors groundwater-level altitudes in Colorado and has been producing groundwater-level altitude and groundwater-level change maps of the unconfined aquifer since 1942 (Davis Engineering Service, Inc., and Principia Mathematica, Inc., 2017).

Groundwater-level data compiled for wells with measurements during two consecutive 5-year time periods indicated that the largest decline in groundwater-level altitudes in the San Luis alluvial basin was approximately $28 \mathrm{ft}$ between 2000 and 2005 (table 3). The largest rise in groundwater-level altitude was approximately $32 \mathrm{ft}$ between 1990 and 1995. Median groundwater-level altitudes were essentially stable in the San Luis alluvial basin, increasing at a rate of $0.01 \mathrm{ft}$ per 5-year period for wells from which groundwater-level measurements were collected during 50 percent or more of the 5-year periods from 1980 to 2015 (table 2). Wells used to assess the rate of groundwater-level change are clustered in the Alamosa Valley area east of Del Norte, Colo., and in the Sunshine ValleyCostilla Plain area north of Questa (fig. 12), with both areas showing a slight increase in water levels. No change (less than a $0.1-\mathrm{ft}$ rise or decline) was measured in 36 percent of the wells in the San Luis alluvial basin. A median groundwaterlevel decline of $0.1 \mathrm{ft}$ or greater was measured in 33 percent of the wells in the San Luis alluvial basin.

Within the San Luis alluvial basin, sufficient groundwater-level data to develop grids representing the time periods evaluated for this study (1980-2015) primarily existed in areas with higher groundwater use in the northern part of the basin and in areas along and east of the Rio Grande (figs. 13-16). These areas of higher groundwater use correspond to the Alamosa basin in Colorado and the Sunshine Valley-Costilla Plain area in New Mexico that are described in the "Hydrogeologic Framework" section of this report. In general, groundwater-level change maps show larger temporal changes in the Sunshine Valley-Costilla Plain and Taos Plateau areas (fig. 2A). Specifically, data in an area west of Questa indicated there were variations in groundwater-level changes at the local scale.

Storage changes in the San Luis alluvial basin were determined for an area of approximately $574 \mathrm{mi}^{2}$ (12 percent of the total basin) distributed in five different areas in the basin (fig. 3). Changes in storage were based on specific 
Table 3. Minimum, median, and maximum groundwater-level altitude change for wells that have groundwater-level data for both time periods being evaluated for alluvial basins in the upper Rio Grande Basin, in Colorado, New Mexico, Texas, and Mexico.

[Groundwater levels altitude are measured in feet. Negative values indicate a decline in groundwater-level altitude (alternatively, an increase in depth to groundwater) during the study period. Count, number of wells with measurements used for computations; - , insufficient data]

\begin{tabular}{|c|c|c|c|c|c|c|c|c|c|c|c|c|c|c|}
\hline Date range & Parameter & San Luis & Española & $\begin{array}{l}\text { Middle Rio } \\
\text { Grande }\end{array}$ & $\begin{array}{c}\text { San } \\
\text { Agustin }\end{array}$ & Socorro & $\begin{array}{c}\text { La } \\
\text { Jencia }\end{array}$ & $\begin{array}{c}\text { San } \\
\text { Marcial }\end{array}$ & $\begin{array}{c}\text { Alamosa } \\
\text { Creek }\end{array}$ & Engle & Palomas & $\begin{array}{c}\text { Jornada } \\
\text { del } \\
\text { Muerto }\end{array}$ & $\begin{array}{l}\text { Mesilla/ } \\
\text { Conejos- } \\
\text { Médanos }\end{array}$ & $\begin{array}{c}\text { Tularosa- } \\
\text { Hueco }\end{array}$ \\
\hline \multirow[t]{4}{*}{1980 to 1985} & Count & 67 & 29 & 43 & - & - & - & - & - & 1 & 36 & - & 107 & 131 \\
\hline & Minimum & -5.13 & -58.92 & -49.00 & - & - & - & - & - & -0.85 & -11.92 & - & -27.79 & -39.06 \\
\hline & Median & 0.30 & -1.67 & -3.00 & - & - & - & - & - & -0.85 & 0.07 & - & 0.78 & -7.92 \\
\hline & Maximum & 15.72 & 23.70 & 18.08 & - & - & - & - & - & -0.85 & 63.62 & - & 188.30 & 13.16 \\
\hline \multirow[t]{4}{*}{1985 to 1990} & Count & 70 & 62 & 64 & - & 9 & - & 3 & - & 7 & 37 & 25 & 154 & 158 \\
\hline & Minimum & -9.67 & -183.00 & -40.57 & - & -4.00 & - & -0.22 & - & 0.33 & -22.79 & -6.22 & -19.63 & -36.06 \\
\hline & Median & 1.27 & -0.72 & -0.94 & - & 0.09 & - & 0.42 & - & 3.50 & 1.38 & 0.75 & 0.11 & -6.29 \\
\hline & Maximum & 15.42 & 51.61 & 11.50 & - & 3.56 & - & 10.14 & - & 28.31 & 44.25 & 84.13 & 9.51 & 16.26 \\
\hline \multirow[t]{4}{*}{1990 to 1995} & Count & 60 & 51 & 66 & 21 & 10 & - & 2 & 2 & 7 & 32 & 13 & 163 & 174 \\
\hline & Minimum & -16.40 & -198.50 & -15.00 & -13.26 & -4.95 & - & -7.80 & -1.35 & -2.75 & -29.49 & -38.62 & -13.66 & -33.49 \\
\hline & Median & 0.83 & -0.97 & -0.95 & 0.35 & 0.19 & - & -4.87 & -0.74 & 0.22 & 0.32 & -1.31 & 0.11 & -4.84 \\
\hline & Maximum & 31.82 & 4.14 & 3.03 & 3.15 & 18.10 & - & -1.93 & -0.12 & 3.55 & 24.38 & 4.00 & 31.10 & 7.86 \\
\hline \multirow[t]{4}{*}{1995 to 2000} & Count & 69 & 33 & 113 & 11 & 3 & - & 1 & - & 1 & 66 & 11 & 148 & 129 \\
\hline & Minimum & -5.30 & -294.38 & -14.39 & -1.73 & -1.21 & - & 1.08 & - & -2.08 & -8.79 & -13.38 & -7.64 & -21.68 \\
\hline & Median & -0.29 & -2.10 & -1.00 & 0.03 & -0.18 & - & 1.08 & - & -2.08 & -0.53 & 0.05 & -0.20 & -2.92 \\
\hline & Maximum & 16.18 & 3.13 & 172.15 & 14.12 & -0.12 & - & 1.08 & - & -2.08 & 10.47 & 39.65 & 14.47 & 40.87 \\
\hline \multirow[t]{4}{*}{2000 to 2005} & Count & 37 & 43 & 111 & - & 3 & - & 1 & - & 1 & 55 & 11 & 137 & 99 \\
\hline & Minimum & -27.69 & -163.45 & -60.86 & - & -0.64 & - & 0.47 & - & 1.79 & -10.31 & -9.01 & -16.70 & -21.23 \\
\hline & Median & -1.66 & -0.91 & -1.07 & - & -0.17 & - & 0.47 & - & 1.79 & -2.02 & -0.38 & -1.65 & -3.60 \\
\hline & Maximum & 13.21 & 274.94 & 8.33 & - & 1.84 & - & 0.47 & - & 1.79 & 11.61 & 4.36 & 5.44 & 17.50 \\
\hline \multirow[t]{4}{*}{2005 to 2010} & Count & 291 & 73 & 163 & - & 7 & - & 4 & - & 1 & 29 & 10 & 123 & 33 \\
\hline & Minimum & -16.75 & -21.19 & -22.19 & - & -5.43 & - & -1.78 & - & -1.83 & -29.70 & -40.49 & -14.25 & -13.30 \\
\hline & Median & 1.34 & -0.49 & 0.39 & - & 0.36 & - & -0.93 & - & -1.83 & 0.02 & -1.20 & -0.36 & -1.10 \\
\hline & Maximum & 17.98 & 277.07 & 40.45 & - & 3.38 & - & 1.25 & - & -1.83 & 56.90 & 71.12 & 8.85 & 5.65 \\
\hline \multirow[t]{4}{*}{2010 to 2015} & Count & 336 & 56 & 120 & 50 & 11 & 2 & 6 & 14 & 5 & 32 & 10 & 109 & 4 \\
\hline & Minimum & -19.25 & -12.80 & -18.50 & -3.92 & -6.08 & -6.75 & -2.48 & -6.05 & -7.77 & -87.37 & -6.29 & -14.40 & -2.30 \\
\hline & Median & -2.78 & -0.07 & 1.36 & -0.13 & -1.25 & -5.98 & -0.36 & -0.60 & -4.17 & -1.60 & 2.46 & -3.30 & -1.85 \\
\hline & Maximum & 11.84 & 224.73 & 129.02 & 8.06 & 7.03 & -5.21 & 13.22 & 0.56 & 4.37 & 8.24 & 7.65 & 17.96 & -0.61 \\
\hline \multirow[t]{4}{*}{1980 to 2015} & Count & 10 & 9 & 15 & 11 & 1 & - & - & 2 & 1 & 18 & - & 40 & 4 \\
\hline & Minimum & -9.46 & -162.64 & -65.26 & -34.00 & -60.89 & - & - & -0.09 & 3.36 & -20.27 & - & -16.77 & -1.97 \\
\hline & Median & -1.00 & -37.05 & -6.68 & -1.33 & -60.89 & - & - & 1.36 & 3.36 & -1.93 & - & -5.14 & 0.69 \\
\hline & Maximum & 7.87 & 6.74 & 29.84 & -0.58 & -60.89 & - & - & 2.81 & 3.36 & 106.84 & - & 50.03 & 3.11 \\
\hline
\end{tabular}




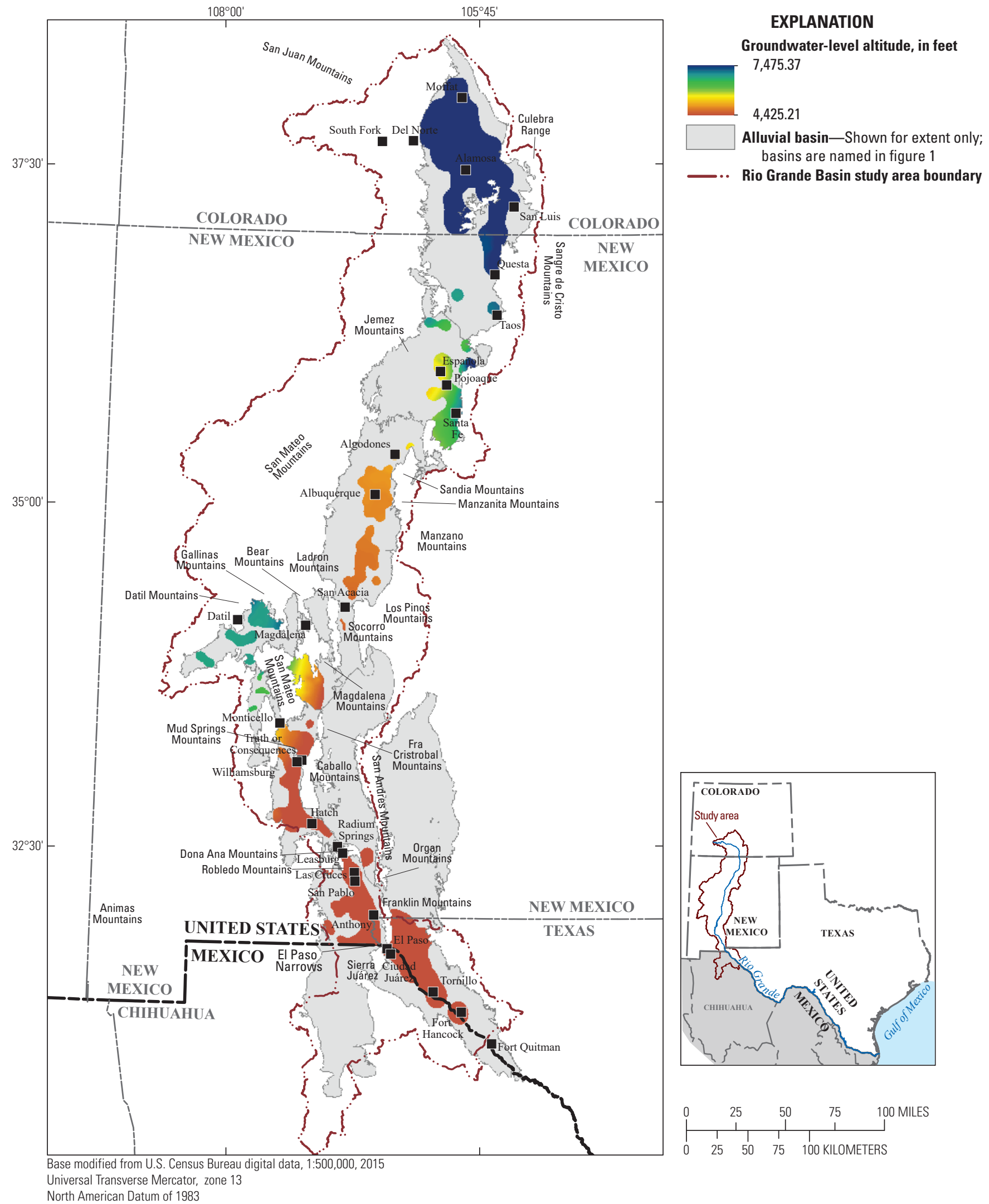

Figure 4. Map showing median 1980 groundwater-level altitude for the upper Rio Grande alluvial basins in Colorado, New Mexico, and Texas, United States, and Chihuahua, Mexico, for the 5-year period from November 1977 through March 1982. 


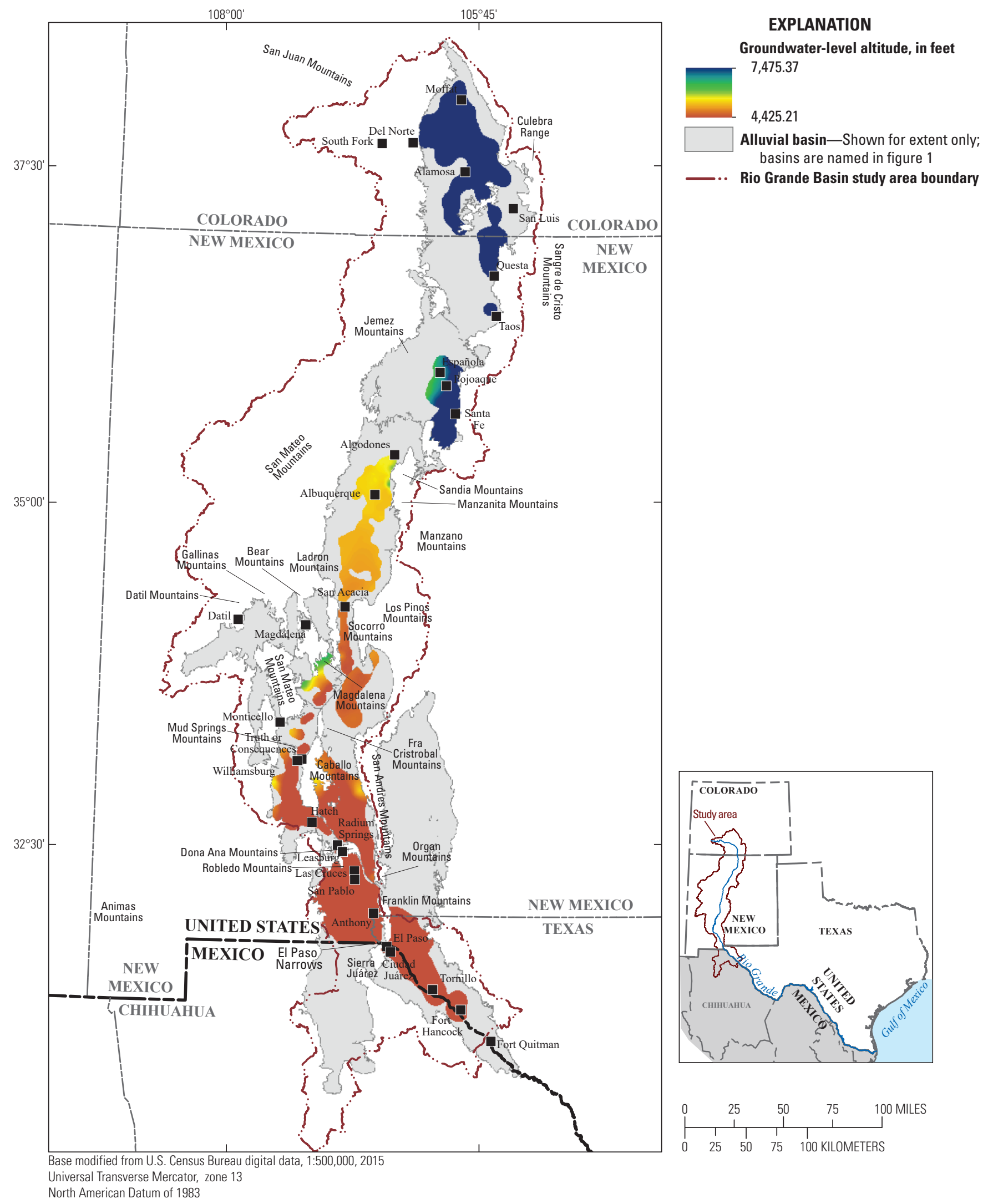

Figure 5. Map showing median 1985 groundwater-level altitude for the upper Rio Grande alluvial basins in Colorado, New Mexico, and Texas, United States, and Chihuahua, Mexico, for the 5-year period from November 1982 through March 1987. 


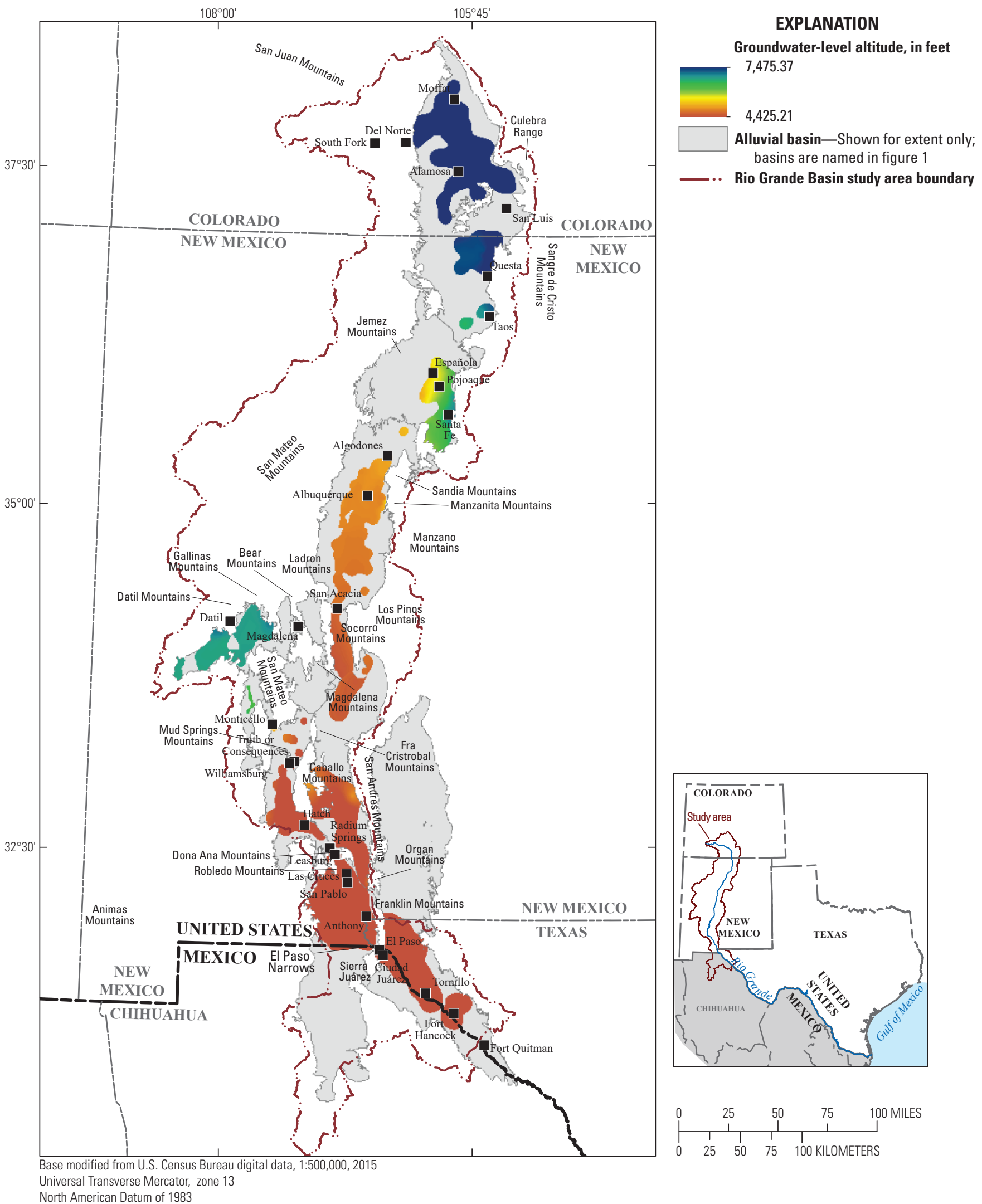

Figure 6. Map showing median 1990 groundwater-level altitude for the upper Rio Grande alluvial basins in Colorado, New Mexico, and Texas, United States, and Chihuahua, Mexico, for the 5-year period from November 1987 through March 1992. 


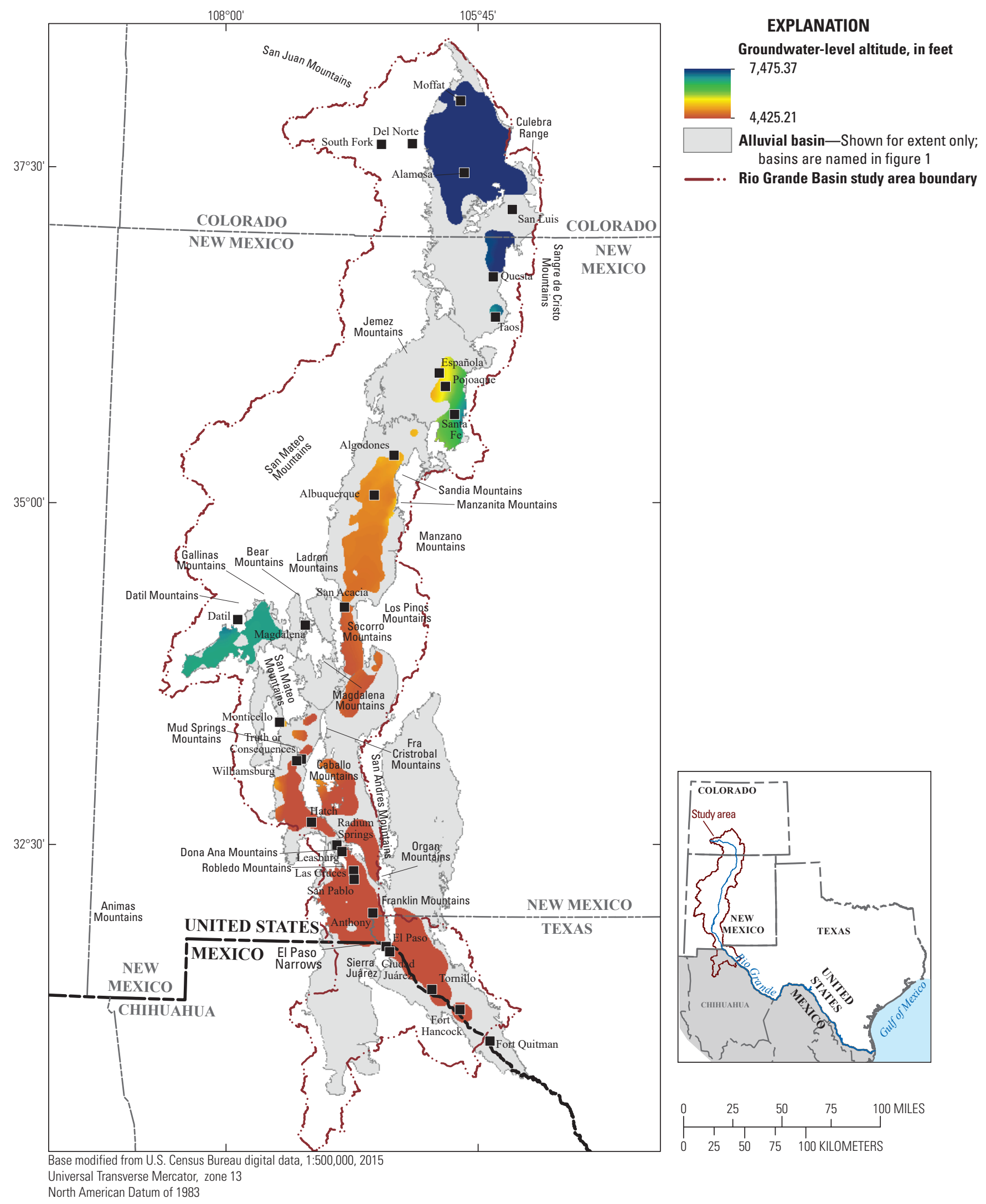

Figure 7. Map showing median 1995 groundwater-level altitude for the upper Rio Grande alluvial basins in Colorado, New Mexico, and Texas, United States, and Chihuahua, Mexico, for the 5-year period from November 1992 through March 1997. 


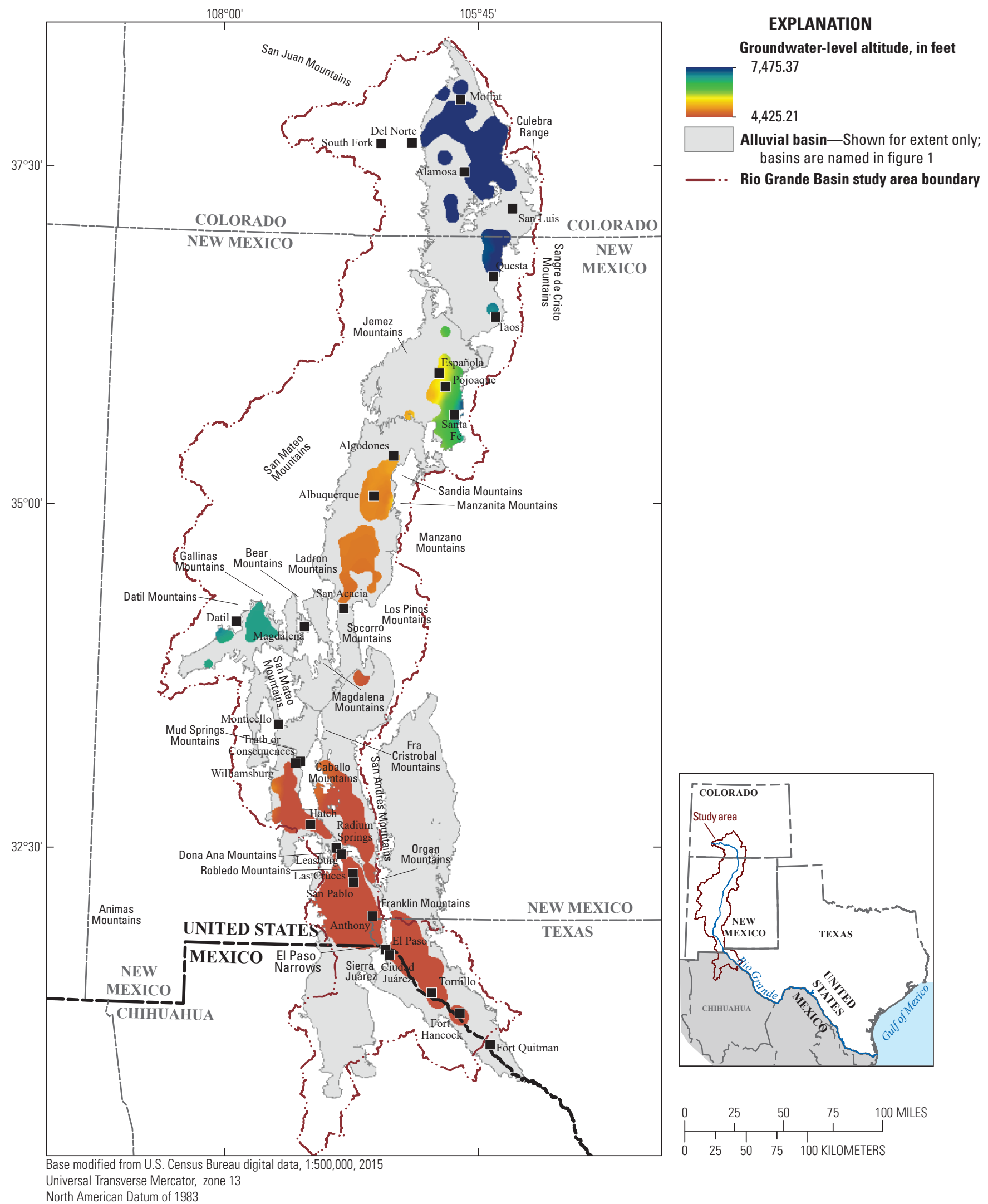

Figure 8. Map showing median 2000 groundwater-level altitude for the upper Rio Grande alluvial basins in Colorado, New Mexico, and Texas, United States, and Chihuahua, Mexico, for the 5-year period from November 1997 through March 2002. 


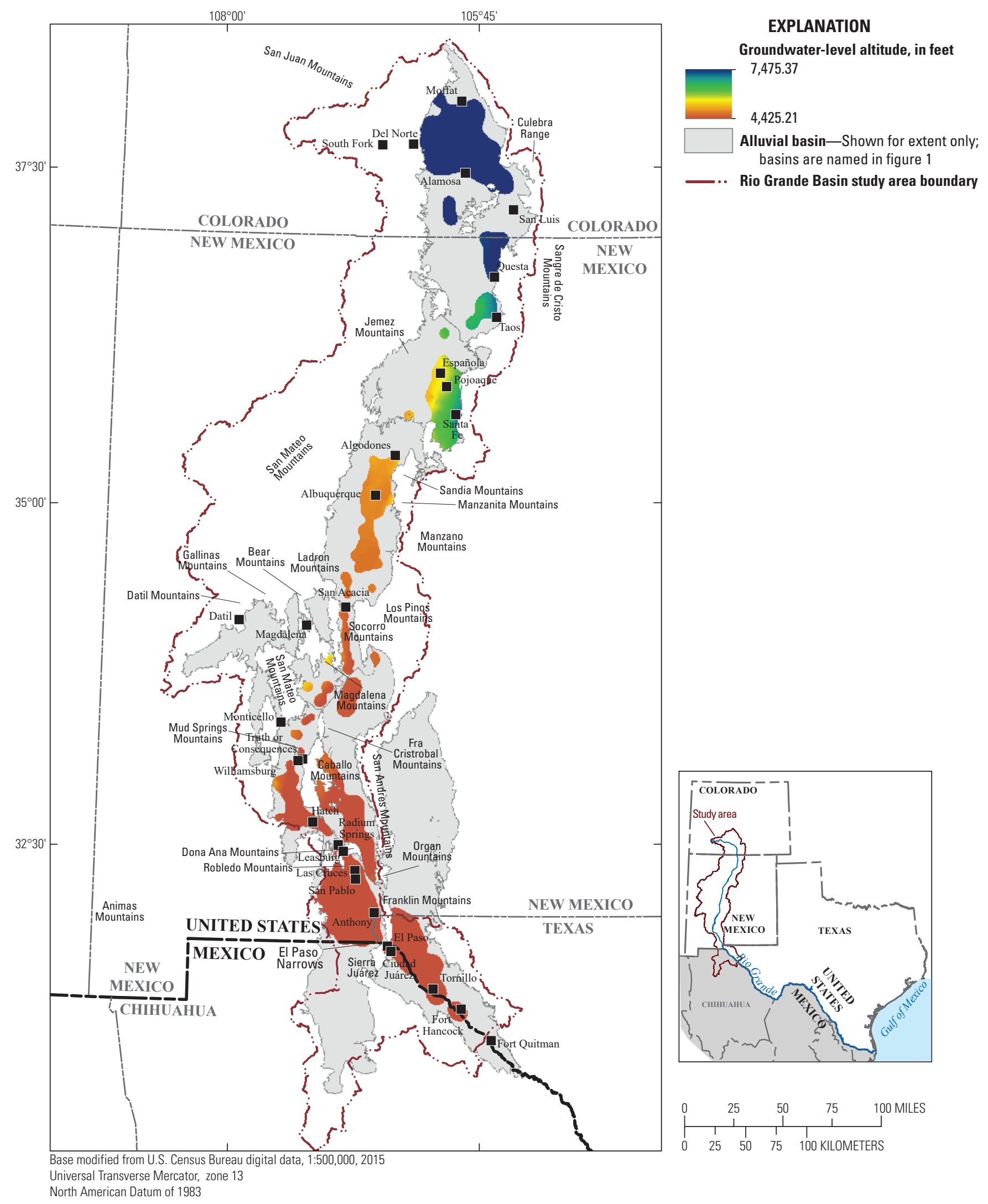

Figure 9. Map showing median 2005 groundwater-level altitude for the upper Rio Grande alluvial basins in Colorado, New Mexico, and Texas, United States, and Chihuahua, Mexico, for the 5-year period from November 2002 through March 2007. 


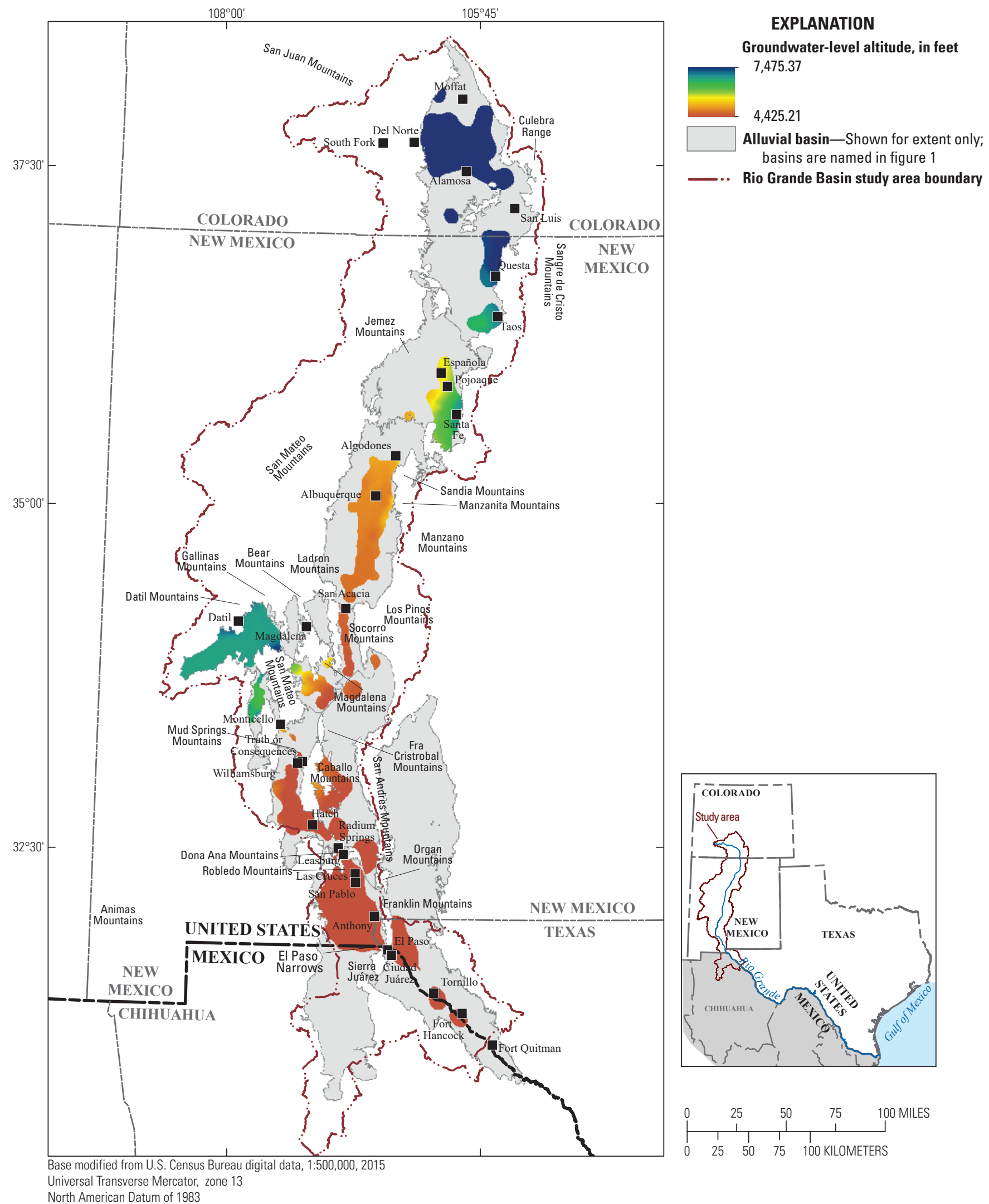

Figure 10. Map showing median 2010 groundwater-level altitude for the upper Rio Grande alluvial basins in Colorado, New Mexico, and Texas, United States, and Chihuahua, Mexico, for the 5-year period from November 2007 through March 2012. 


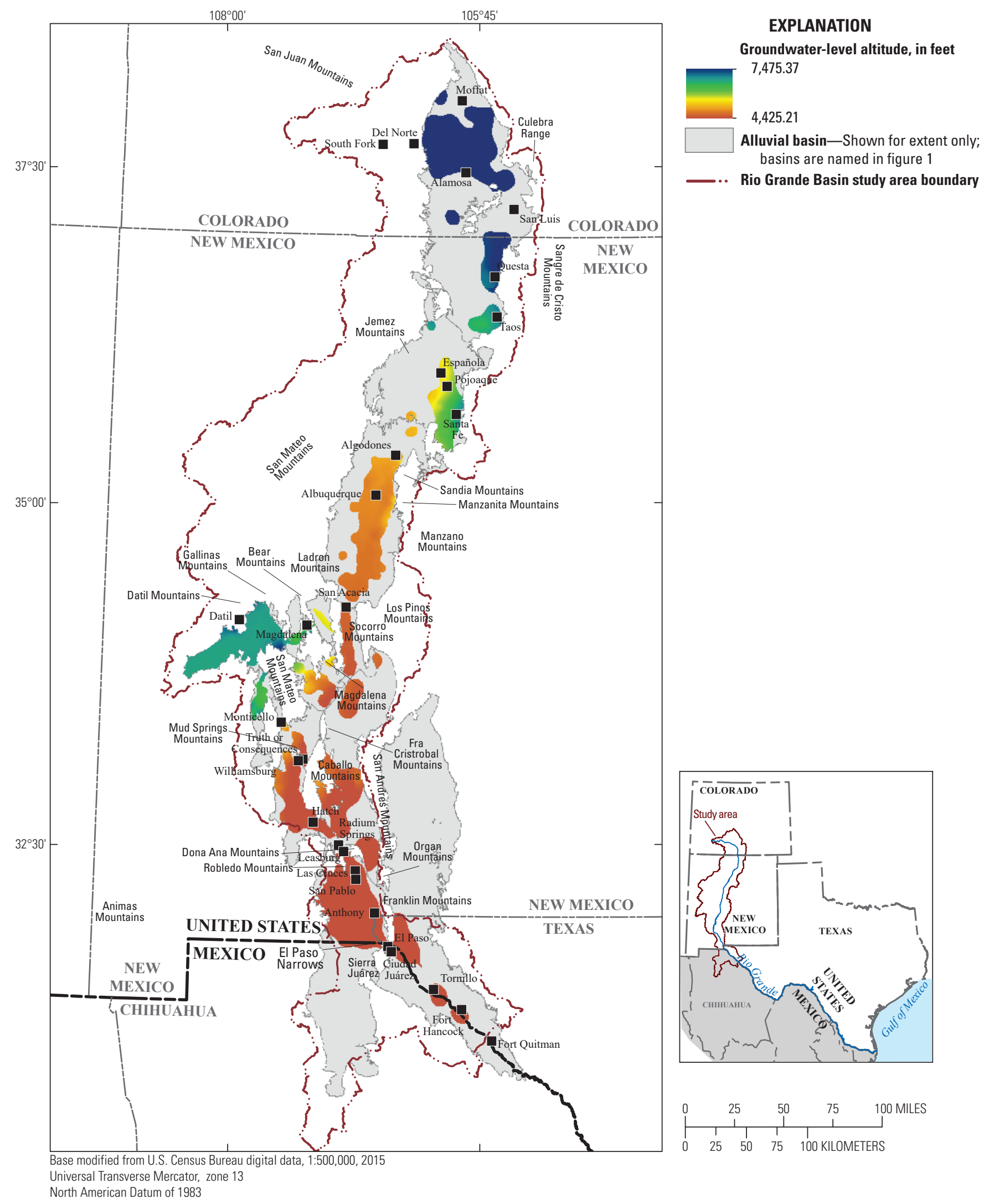

Figure 11. Map showing median 2015 groundwater-level altitude for the upper Rio Grande alluvial basins in Colorado, New Mexico, and Texas, United States, and Chihuahua, Mexico, for the 5-year period from November 2012 through March 2017. 


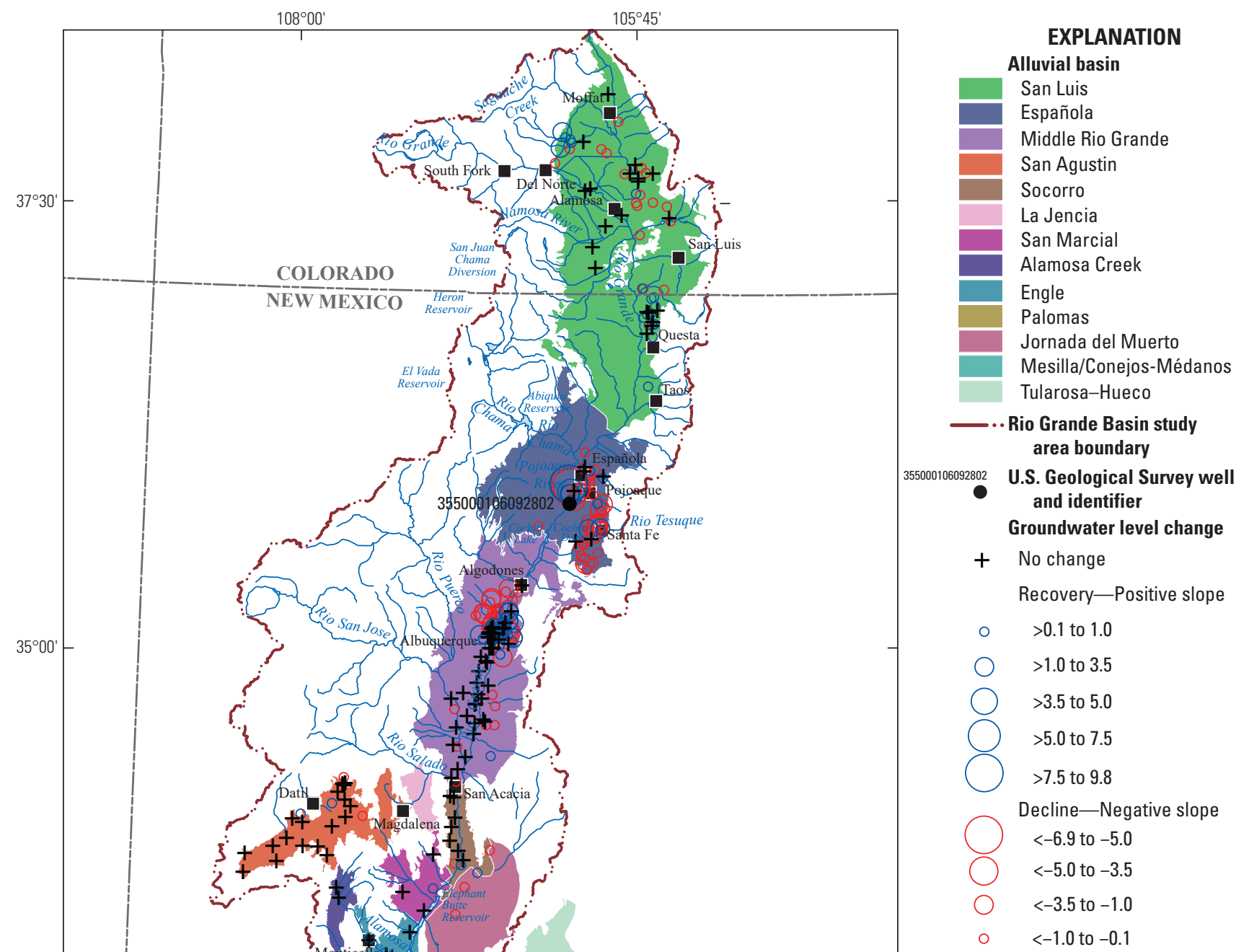

NEW MEXICO

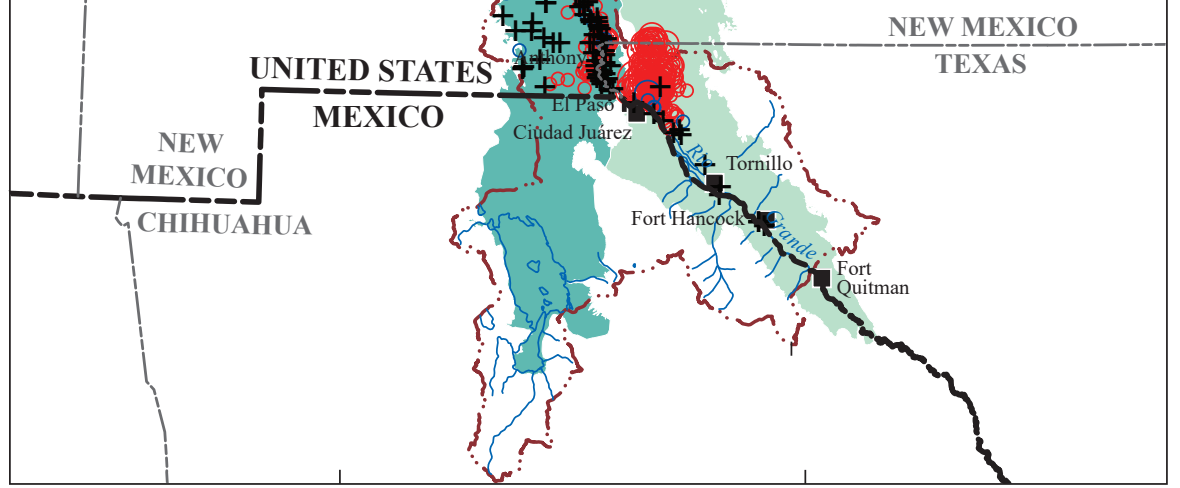

Base modified from U.S. Census Bureau digital data, 1:500,000, 2015

Universal Transverse Mercator, zone 13

North American Datum of 1983

Figure 12. Map showing approximate groundwater-level changes during 5-year periods based on median slopes derived from lines of best fit for groundwater-level altitudes measured during the study period (1980-2015) at wells in the upper Rio Grande alluvial basins in Colorado, New Mexico, and Texas, United States, and Chihuahua, Mexico. 

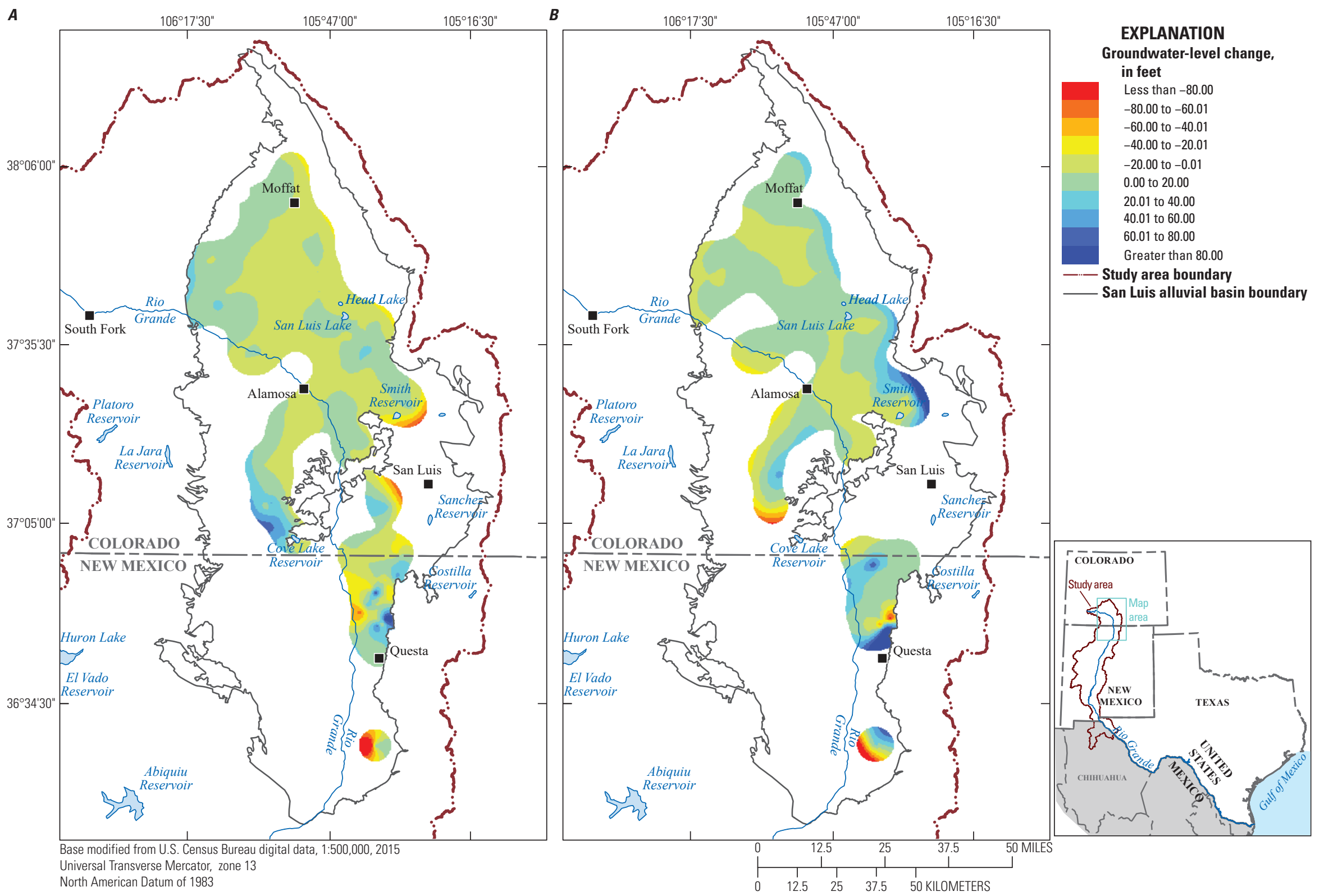

Figure 13. Maps showing median groundwater-level changes for the San Luis alluvial basin during A, 1980-85 and $B$, 1985-90 in Colorado and New Mexico. 

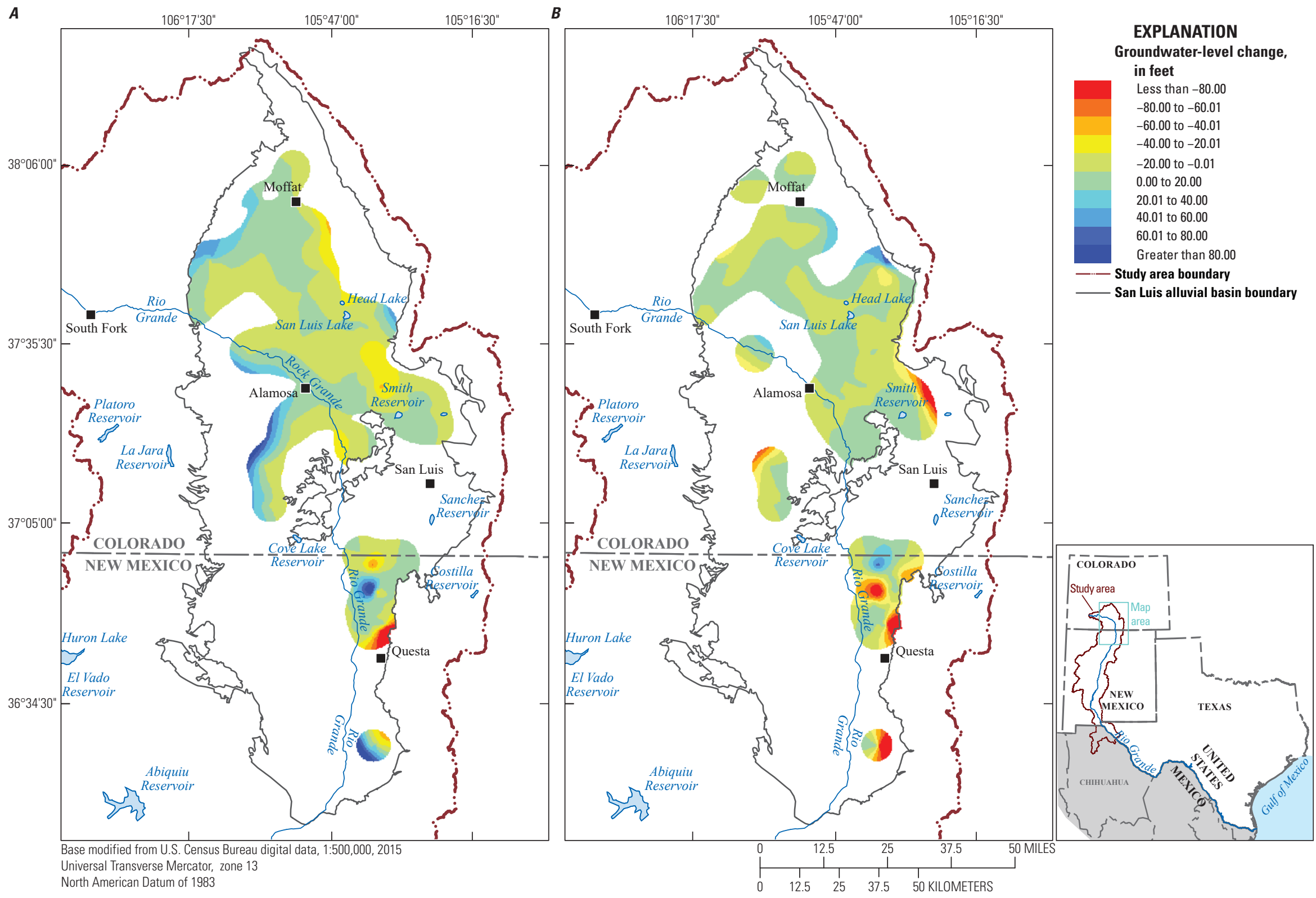

Figure 14. Maps showing median groundwater-level changes for the San Luis alluvial basin during A, 1990-95 and B, 1995-2000 in Colorado and New Mexico. 

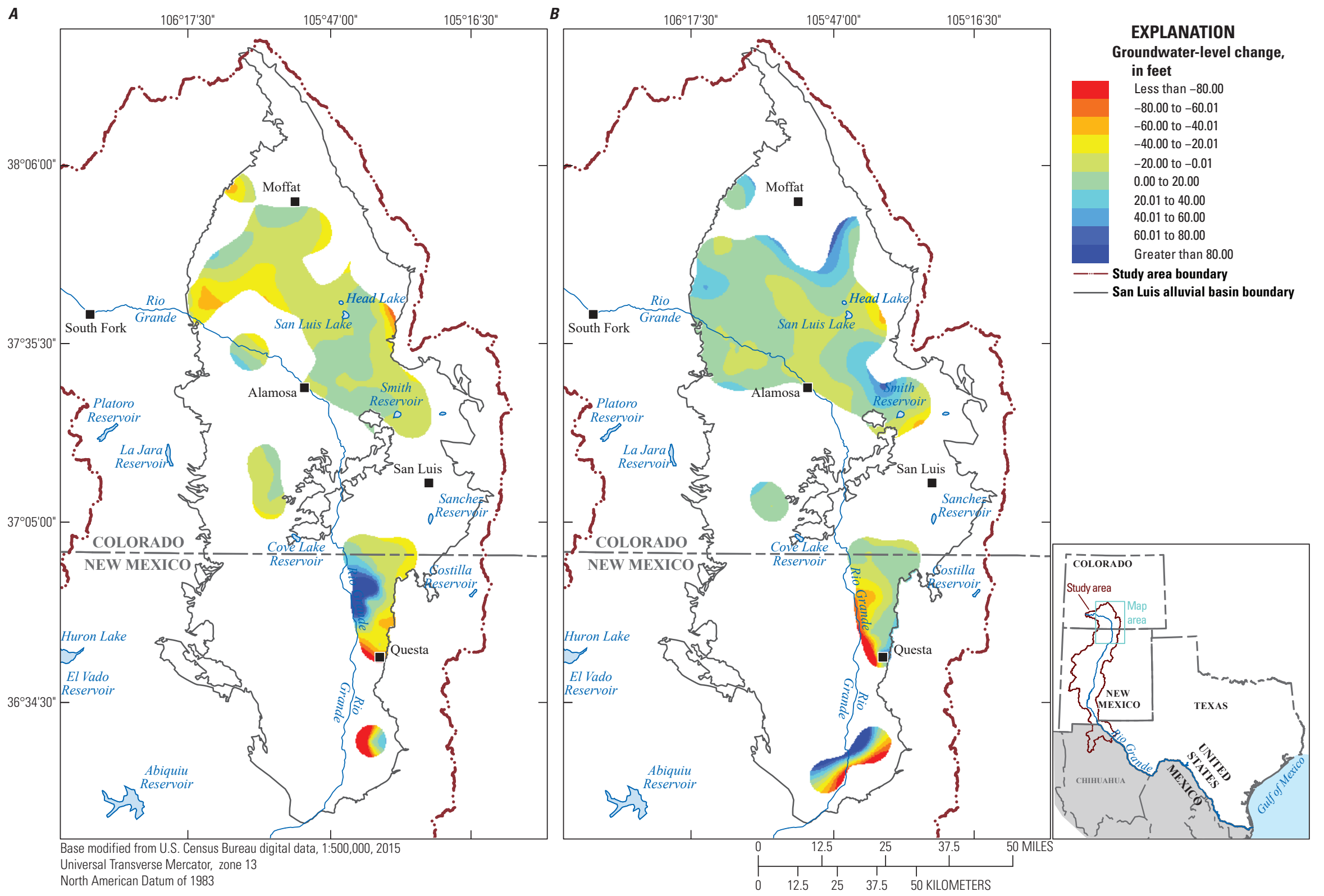

Figure 15. Maps showing median groundwater-level changes for the San Luis alluvial basin during A, 2000-05 and B, 2005-10 in Colorado and New Mexico. 

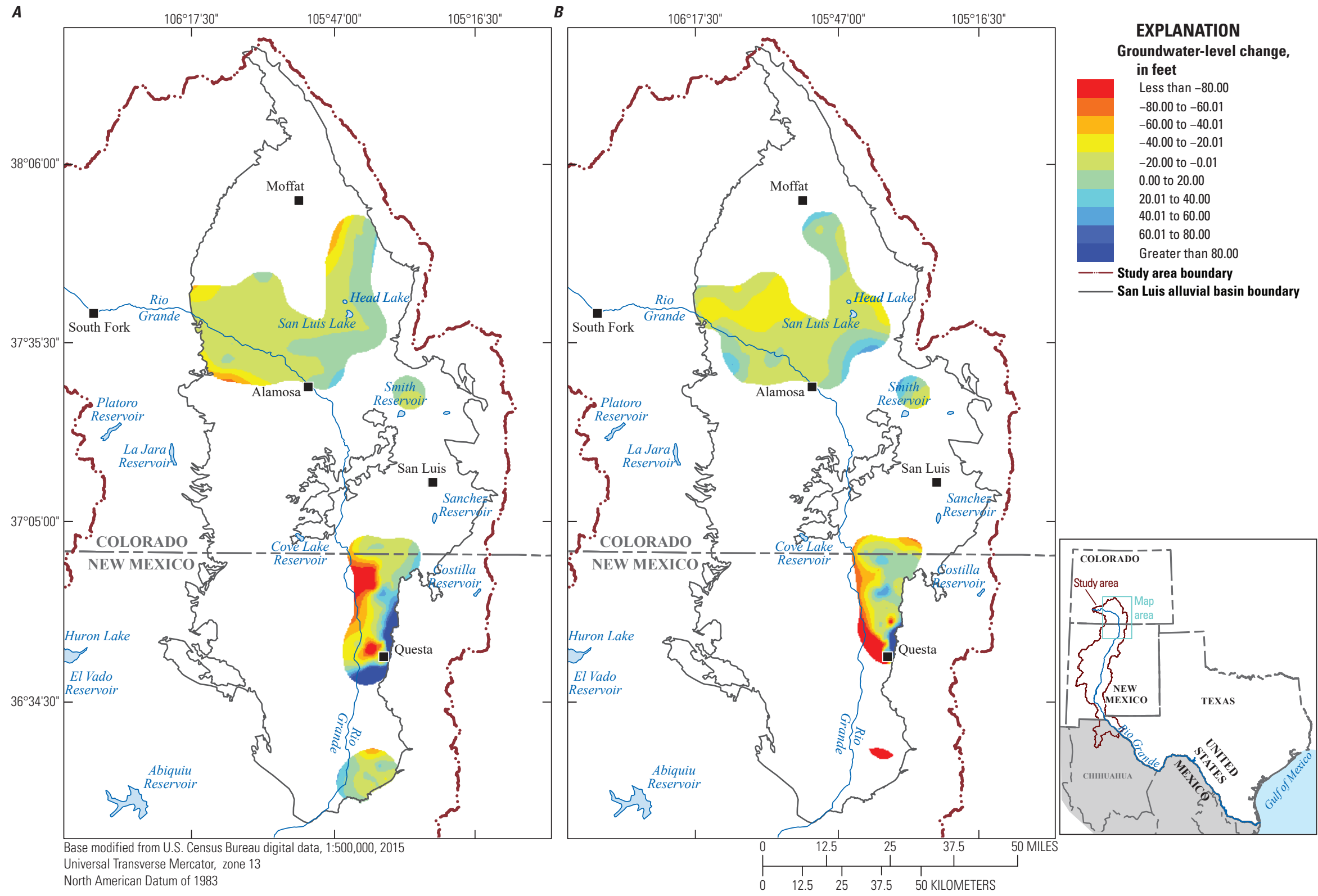

Figure 16. Maps showing median groundwater-level changes for the San Luis alluvial basin during A, 2010-15 and B, 1980-2015 in Colorado and New Mexico. 
yield estimates ranging from 0.05 to 0.24 (Powell and Mutz, 1958; Leonard and Watts, 1988). Smaller specific yield values contribute to more subdued changes in storage, and larger specific yield values contribute to larger changes in storage. In the first two 5-year periods from 1980 to 1990 the amount of groundwater in storage increased before decreasing in the subsequent 5-year periods from 1990 to 2015 . Overall, the cumulative amount of groundwater in storage decreased by as much as -1.05 million acre-feet from 1980 to 2015 when an upper limit for specific yield of 0.24 was used to compute storage (fig. 17).

The current [2021] San Luis alluvial basin groundwaterflow model is the Rio Grande Decision Support System (RGDSS) model (Harmon and others, 2016), which is used to simulate groundwater in the unconfined and confined aquifers in the part of the San Luis Valley in Colorado. Model results indicate periods of both increases and decreases in storage (fig. 18), with a recent period of cumulative increases from about 2005 to about 2010 (figs. 18-19). Changes in storage in the RGDSS model are caused by a combination of changes in simulated inflows and outflows to the aquifer system, mainly recharge (primarily from surface water and irrigation return flow), evapotranspiration, and groundwater withdrawals (fig. 20). Cumulative changes in storage from the RGDSS model during the study period indicate the largest decreases occurred after 2000 (fig. 19), which were offset somewhat by increases in storage during 2005-10. Larger simulated decreases in storage from the RGDSS model (fig. 17) correspond with larger parts of the gridded groundwaterlevel change maps showing declines (figs. 14B, 15A, and $16 A)$. Direct comparisons between the groundwater-flow model results obtained from Harmon and others [2016] and the storage computations from the water-level change maps (figs. 13-16) cannot be made because they cover different lateral spatial extents and different depths.

The RGDSS model simulates a thickness for the Santa Fe aquifer system of as much as almost 9,000 ft. The depth of the deepest groundwater well used for the storage computation is $1,080 \mathrm{ft}$, and the mean depth is about $55 \mathrm{ft}$. Although the modeling results cover different spatial extents, a general pattern of decreasing amounts of groundwater in storage is evident from 1987 through 2005 (figs. 17 and 19). In the San Luis Valley in southern Colorado, groundwater depletion in the unconfined aquifer north and east of the Rio Grande in parts of Rio Grande, Saguache, and Alamosa Counties between 1987 and 2005 was followed by a recovery of approximately $250,000 \mathrm{ac}-\mathrm{ft}\left(308 \mathrm{Mm}^{3}\right)$ in storage between late 2013 and early 2018 , following the implementation of a pay-to-pump

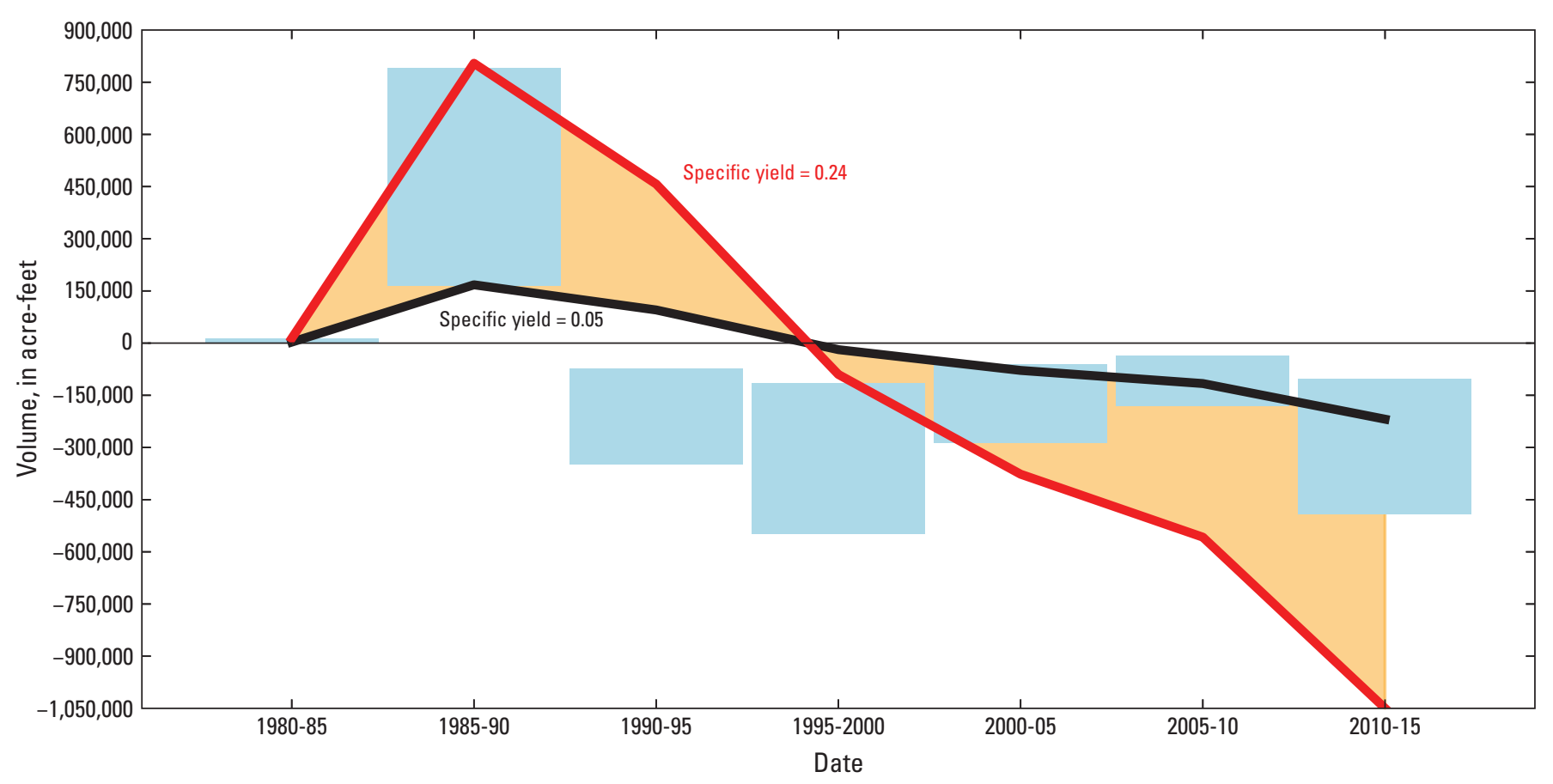

Figure 17. Graph showing ranges of groundwater-storage changes for the San Luis alluvial basin for 5-year periods (blue) and cumulative storage change from 1980 to 2015 (red); the black line represents cumulative storage change determined by using specific yield of 0.05 , and the red line represents cumulative storage change determined by using specific yield of 0.24 . Blue bars represent the range of storage volume change with one end representing the lower value of specific yield and the other end representing the upper value of specific yield. 


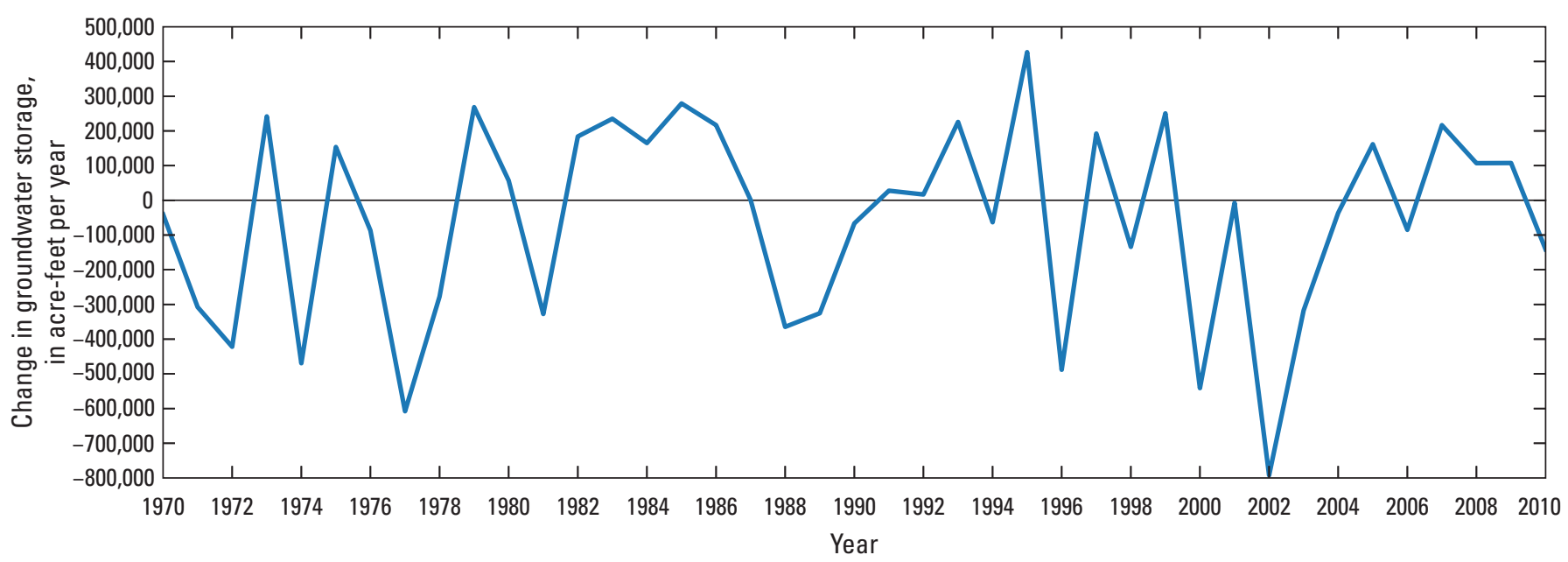

Figure 18. Graph showing simulated changes in groundwater storage in the San Luis Basin, Colorado; data are from Harmon and others (2016).

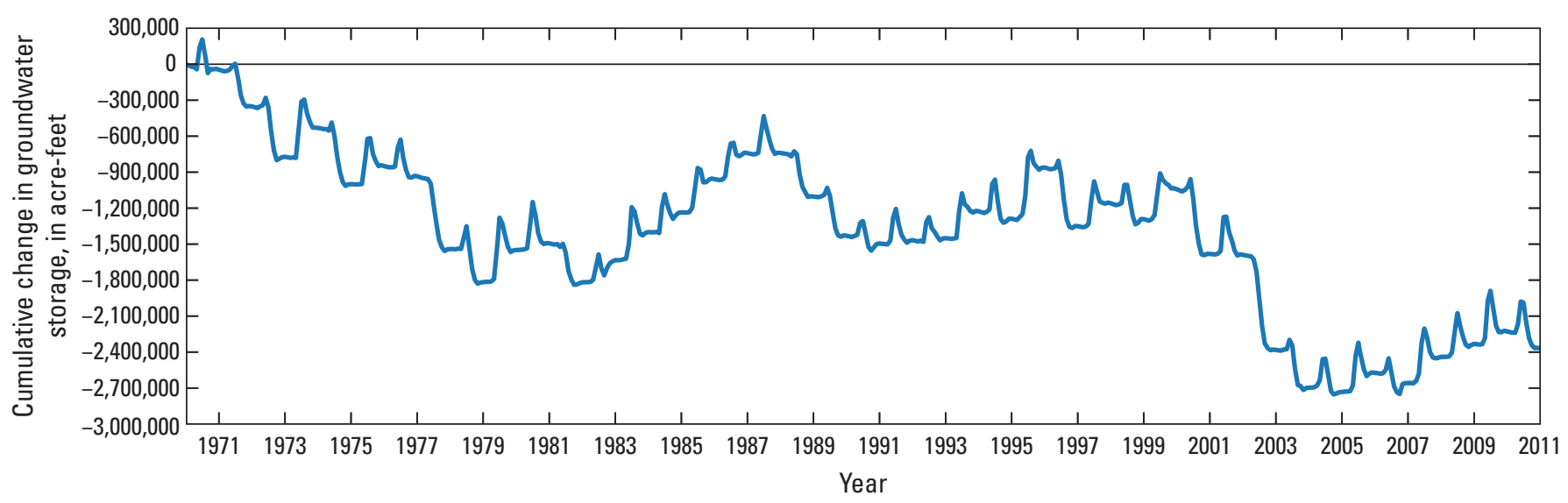

Figure 19. Graph showing cumulative storage changes for San Luis Basin, Colorado, during 1970-2010; data are from Harmon and others (2016).

groundwater program (Rio Grande Water Conservation District, 2018). However, a severe drought that began in 2002 in the upper Rio Grande Valley and has persisted almost uninterrupted to the present [2021], particularly in southern Colorado, has undone some of the effects of the conservation efforts (Bowlin, 2019).

The Sunshine Valley-Costilla Plain area is a small agricultural area north of Questa that has been using groundwater from the water-bearing units of the Santa Fe Group for farming since the 1950s. Between the 1950s and 1970s, there were groundwater-level declines of as much as $50 \mathrm{ft}$ in the area
(Garrabrant, 1993). Since 1980, groundwater-level altitudes have recovered because groundwater withdrawals for irrigation have decreased; however, increases in municipal demand, particularly in and near Española and Santa Fe, have offset some of the decreases in groundwater withdrawals for irrigation. In 2006, Santa Fe County purchased the land and water rights from one of the last remaining farms in the Sunshine Valley-Costilla Plain area. The farm owned approximately $1,750 \mathrm{ac}-\mathrm{ft}\left(2.16 \mathrm{Mm}^{3}\right)$ of water rights that were transferred to Santa Fe County and the Nambé, Pojoaque, Tesuque, and San Ildefonso Pueblos (Logan, 2015). 


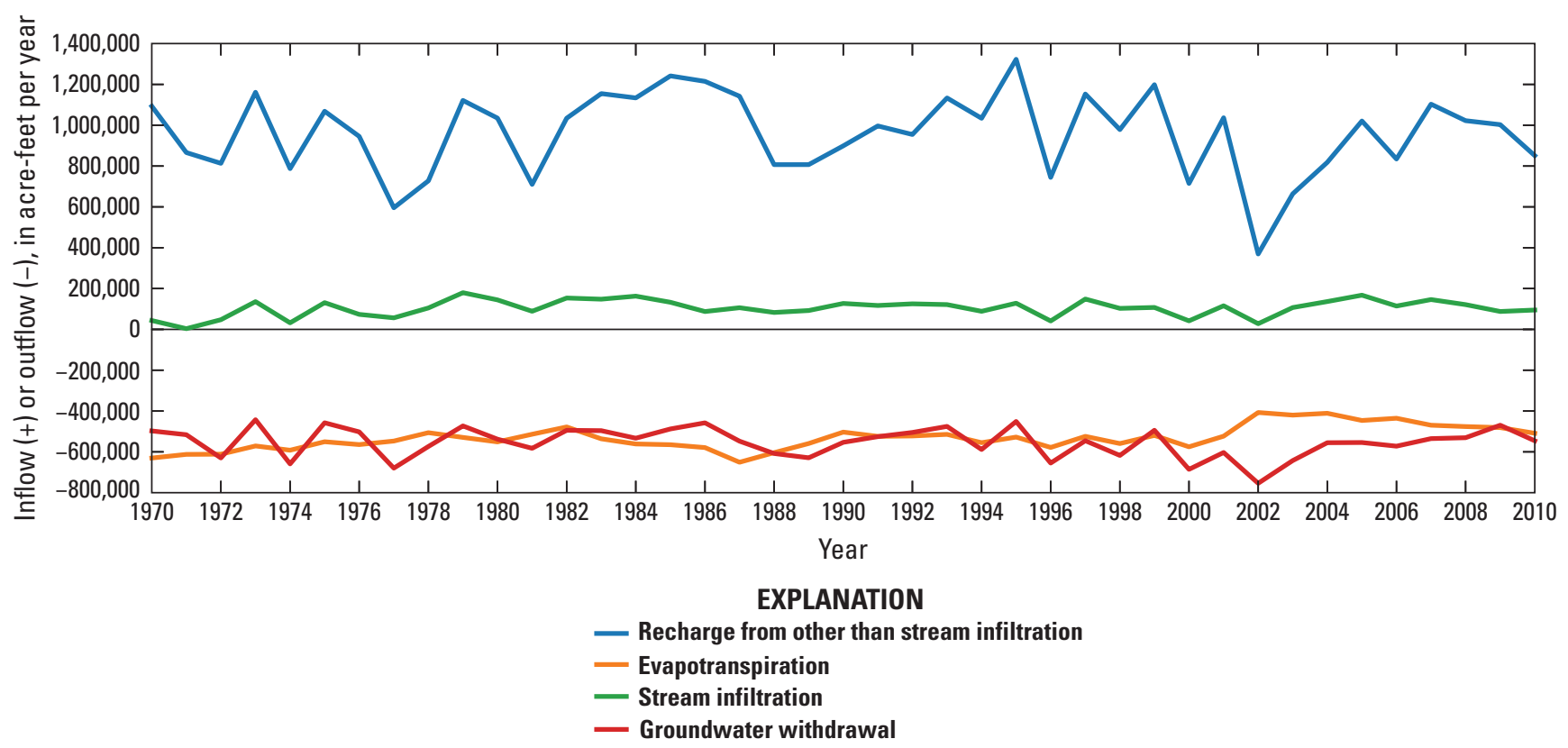

Figure 20. Graph showing selected simulated inflows and outflows within the San Luis Basin, Colorado; data are from Harmon and others (2016). Positive values are associated with inflow to the aquifer, whereas negative values refer to outflow from the aquifer.

\section{Española Alluvial Basin}

In the Española alluvial basin, groundwater is used primarily near Santa Fe in the southeastern part of the basin. Similar to most areas in the upper Rio Grande Basin, more groundwater-level data are available for areas of extensive groundwater use than areas with little use. Because of the concentration of groundwater data in the southeastern part of the basin, groundwater-level change maps could only be completed for part of the Española alluvial basin (figs. 21-24). To help fully understand the effects of extensive groundwater withdrawals in localized areas in the Española alluvial basin, groundwater-level data were included from production wells for periods when the wells were not actively being pumped. Groundwater-level data measured in the Buckman well field generally displayed characteristics of groundwater-level data typical of data collected from unconfined wells. However, near the end of the study period, groundwater-level data from wells in the Buckman well field displayed characteristics of groundwater-level data typical of data collected from confined wells. During these times, the groundwater altitude was above land surface (that is, altitude at which the groundwater level would have stood in tightly cased well extending above the land-surface altitude).

Large rises in groundwater-level altitudes of approximately 275,277 , and $225 \mathrm{ft}$ were observed during 2000-05, 2005-10, and 2010-15, respectively (table 3). Median groundwater-level altitudes in the Española alluvial basin declined slightly at a rate of $-0.17 \mathrm{ft}$ per 5 -year period in wells from which groundwater-level measurements were collected during 50 percent or more of the 5 -year periods from 1980 to
2015 (table 2). The largest 5-year declines in groundwaterlevel altitudes were approximately 183, 199, 294, and $163 \mathrm{ft}$ during 1985-90, 1990-95, 1995-2000, and 2000-05, respectively, when most of the groundwater-level altitude data were obtained from wells in the Buckman well field or from other wells clustered around Santa Fe (figs. $2 A$ and 22B). The majority of the wells in the Española alluvial basin (71 percent) showed declines (with the largest rate of change in the Buckman well field), and groundwater-level altitudes in 25 percent of those wells declined at rates in excess of $1 \mathrm{ft}$ per 5 -year period.

Within the Española alluvial basin, the amount of groundwater in storage varied as municipal demand increased the demand on groundwater resources and as conservation efforts were implemented. Storage changes for the Española alluvial basin were estimated for an area of approximately $386 \mathrm{mi}^{2}$ (16 percent of the basin). Changes in storage were based on specific yield estimates of 0.1 to 0.2 (Hearne, 1985; McAda and Wasiolek, 1988; Frenzel, 1995). Smaller specific yield values contributed to more subdued changes, and larger specific yield values contributed to larger changes in storage. During 2000-05 and 2010-15, the amount of groundwater in storage increased; in the remaining 5-year periods, the amount of groundwater in storage decreased, resulting in an overall similar amount of storage in 2015 when compared with 1985 (fig. 25).

McAda and Wasiolek (1988) developed a groundwaterflow model for the Tesuque aquifer in the Española Basin that simulated groundwater conditions during $1947-82$ by primarily using a specific yield of 0.15 , although a smaller specific yield of 0.05 was used in a small inset area. Based on 


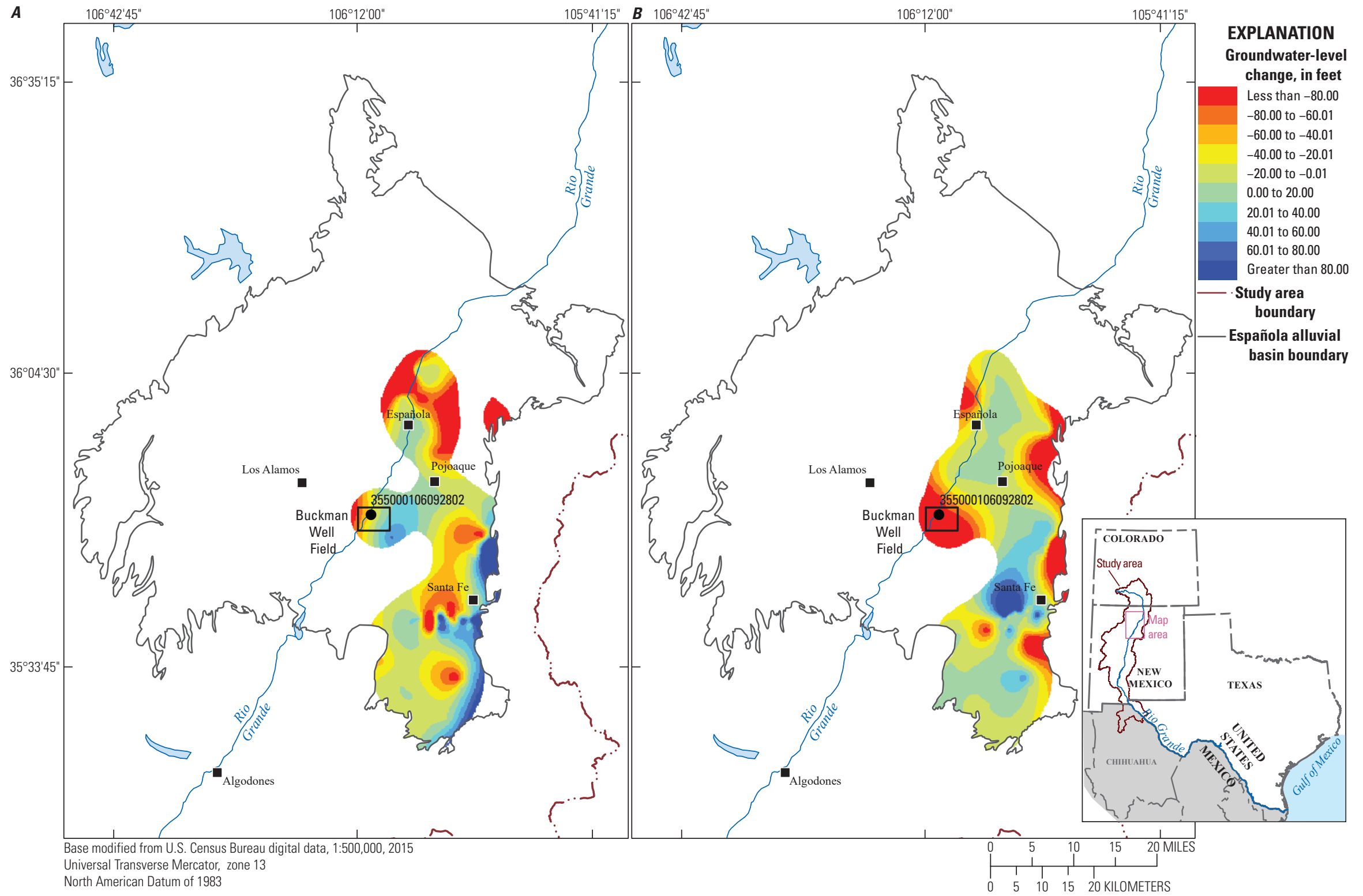

Figure 21. Maps showing median groundwater-level changes for the Española alluvial basin during A, 1980-85 and B, 1985-90 in New Mexico. 


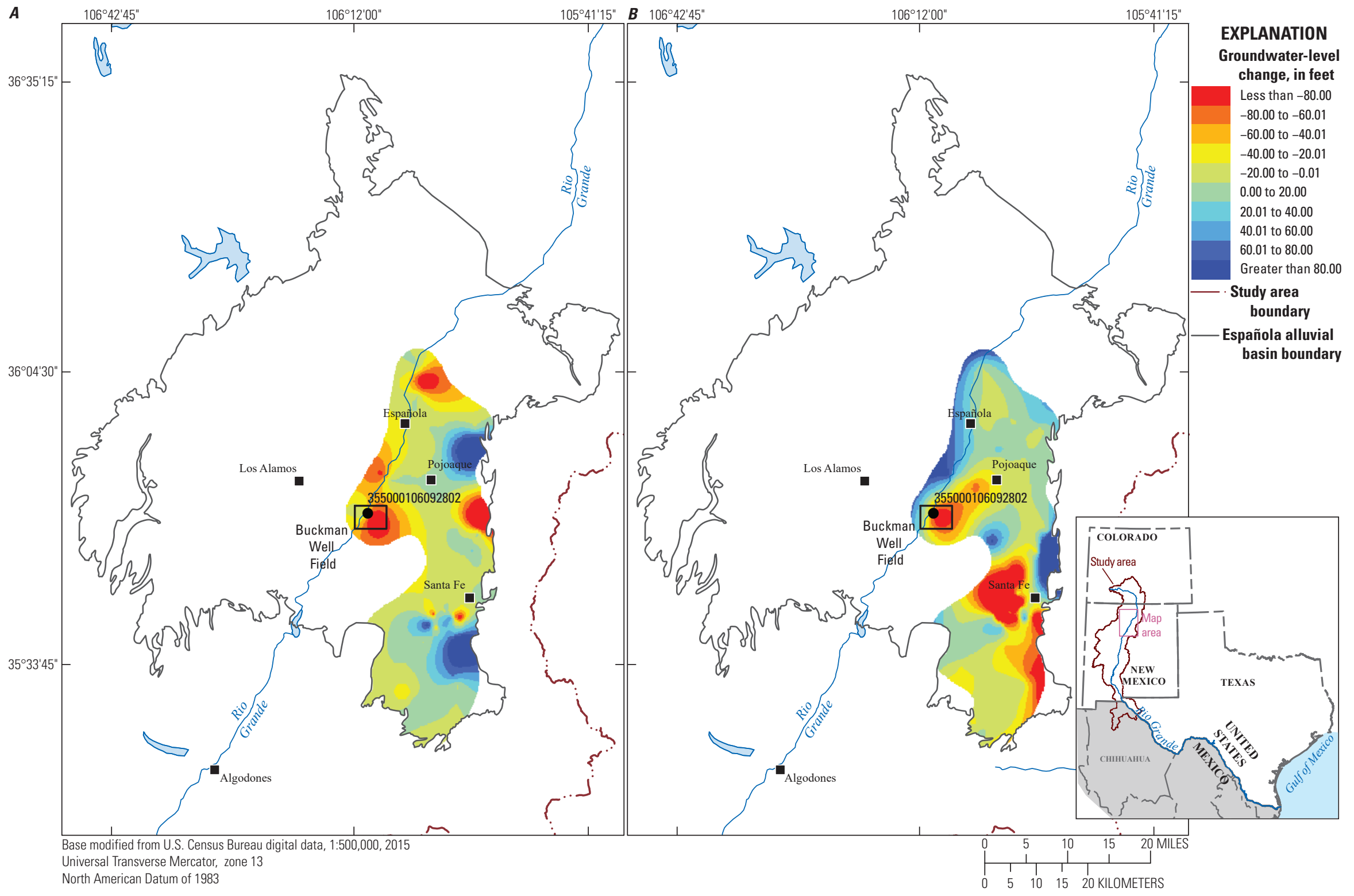

Figure 22. Maps showing median groundwater-level changes for the Española alluvial basin during $A, 1990-95$ and B, 1995-2000 in New Mexico. 


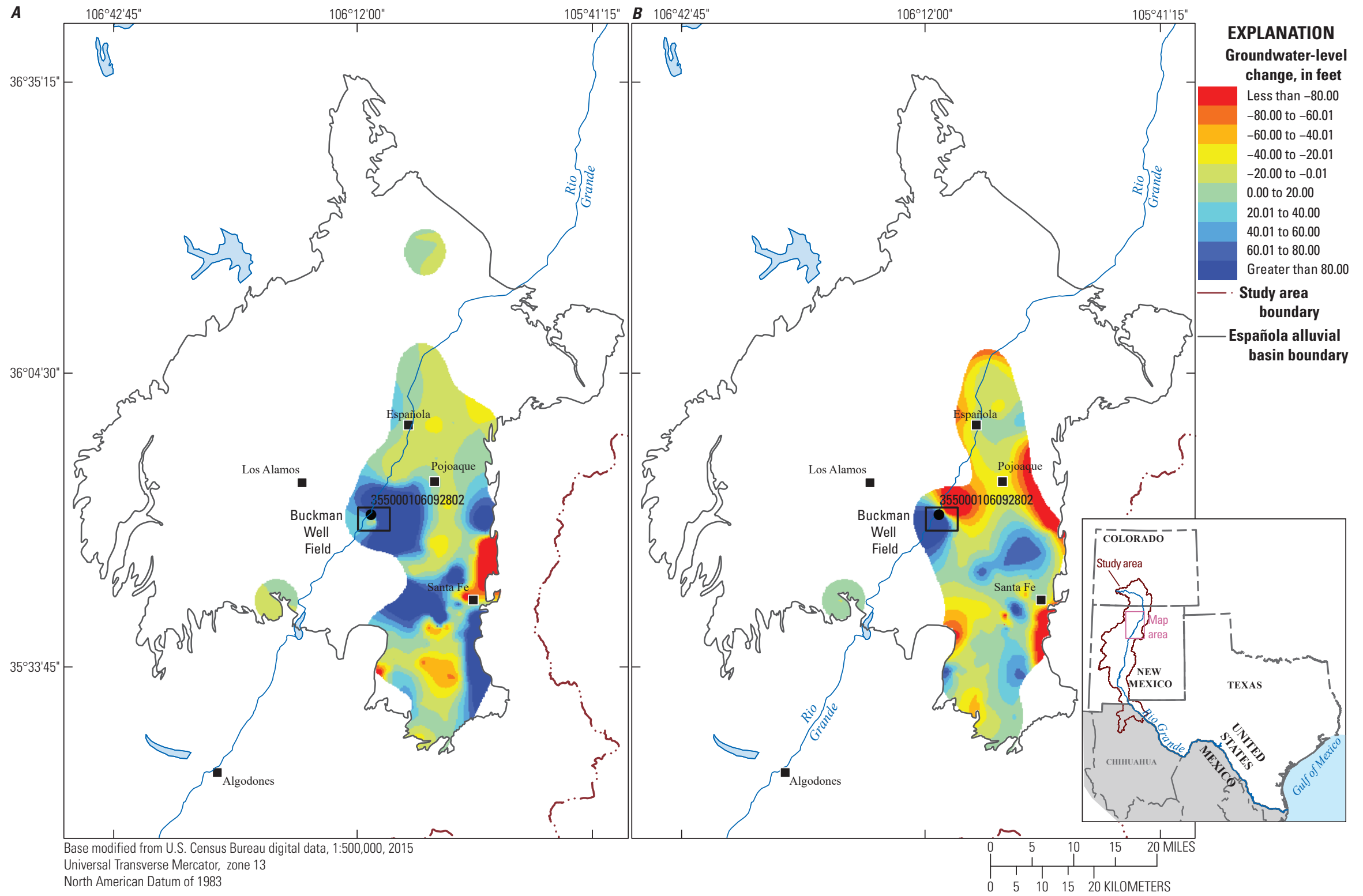

Figure 23. Maps showing median groundwater-level changes for the Española alluvial basin during A, 2000-05 and B, 2005-10 in New Mexico. 


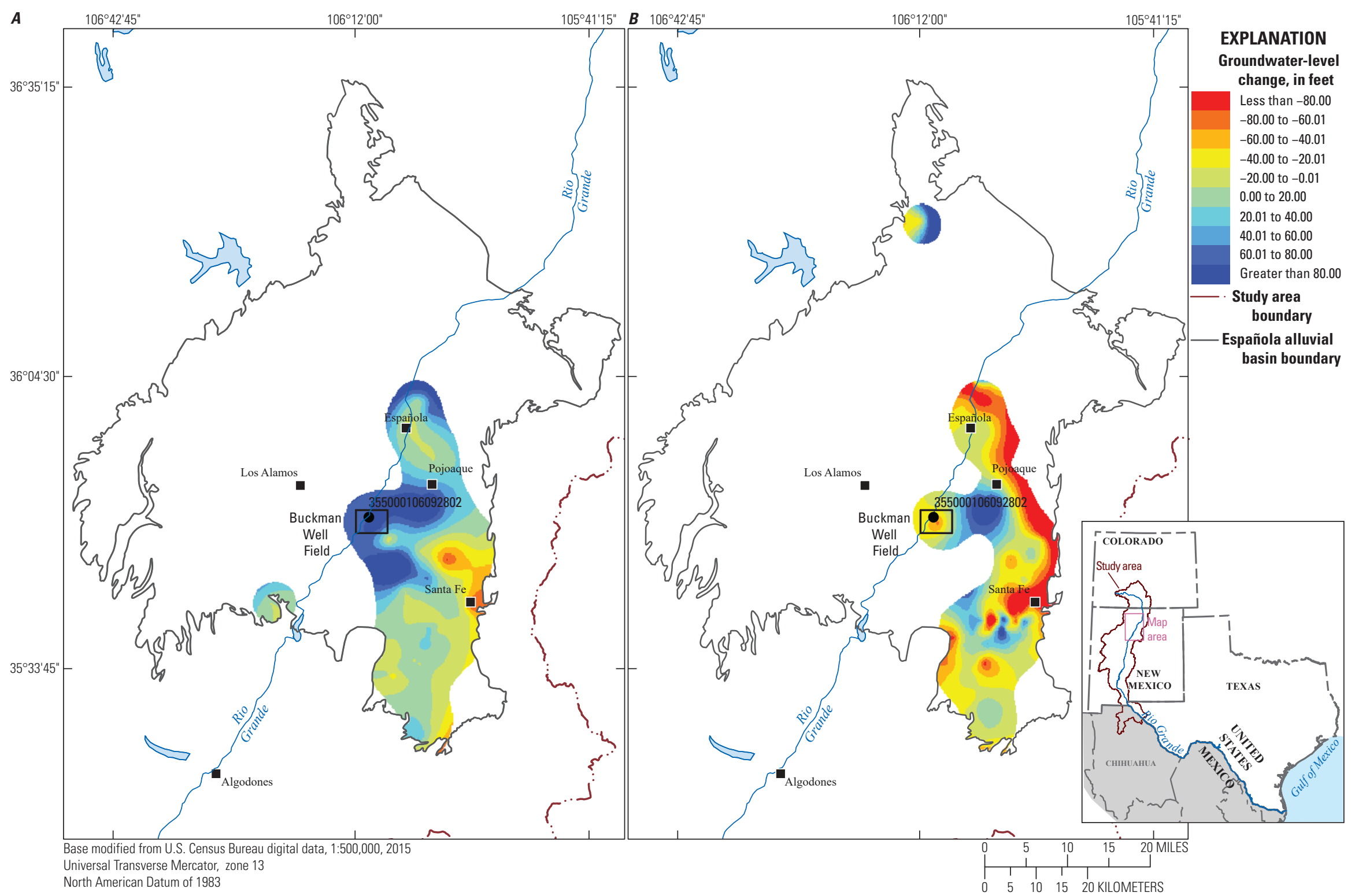

Figure 24. Maps showing median groundwater-level changes for the Española alluvial basin during A, 2010-15 and B, 1980-2015 in New Mexico. 


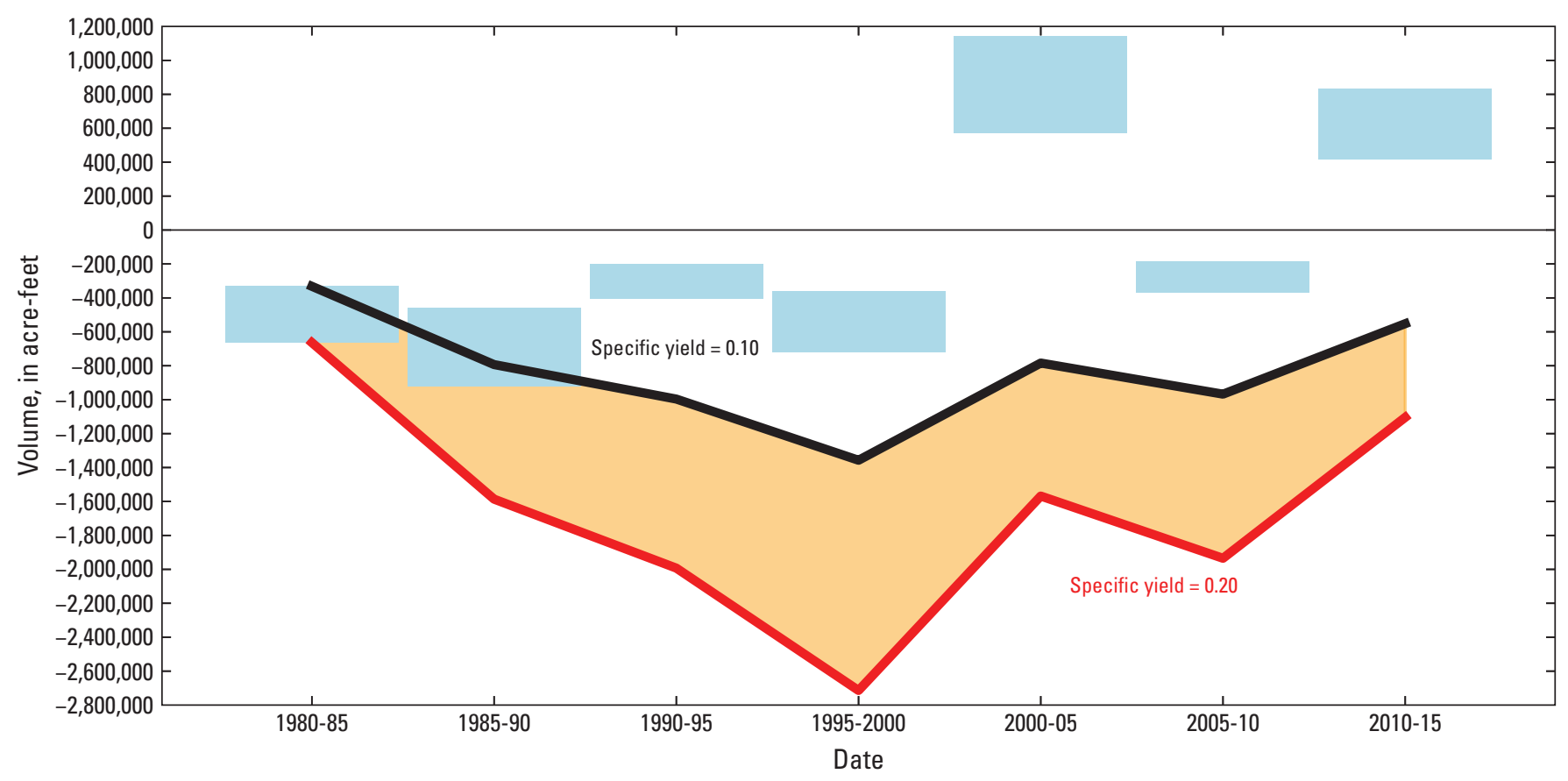

Figure 25. Graph showing ranges of groundwater storage changes for the Española alluvial basin for 5-year periods (blue) and cumulative storage change from 1980 to 2015 (red); the black line represents cumulative storage change using specific yield of 0.10 , and the red line represents cumulative storage change using specific yield of 0.20 . Blue bars represent the range of storage volume change with one end representing the lower value of specific yield and the other end representing the upper value of specific yield.

groundwater-level changes, simulated declines in storage in the Tesuque aquifer during 1947-82 (fig. 26) are representative of a larger area within the Espanola basin (fig. 3) than the area where storage changes were computed. Furthermore, the groundwater-flow model simulates both the unconfined (shallow) and confined (deep) aquifers within this basin, whereas the storage computation based on groundwater-level changes focuses on the unconfined system. The upper layer of the model represents the top $800 \mathrm{ft}$ of the aquifer. The layers below layer 1 represent the confined units. The deepest well for the storage computation from groundwater-level change maps was completed to about $700 \mathrm{ft}$ below land surface; the mean well depth of the wells used to compute storage was about $155 \mathrm{ft}$ below land surface. The groundwater-flow model does not indicate any net gaining periods of storage, whereas storage computed by using the 5 -year median groundwaterlevel altitudes from 1980 to 2015 indicates actual net gains in storage for 2000-05 and for 2010-15 (although these computed values represent a smaller area; fig. 3).

Monthly measurements of groundwater-level altitudes from the Buckman well field production wells are available from 1982 to 2019; groundwater-level altitudes from these wells for the nonirrigation season were included in the data compilation if the measurements were obtained when the pumps were off. Because the Buckman well field is one Santa Fe's groundwater sources, in the mid-1980s, researchers began studying the link between groundwater withdrawals from the Buckman well field and reduced streamflow in the Rio Grande ("Hydrogeologic Framework" section of this report). The USGS installed monitoring wells in the mid-1980s to help with this assessment. USGS site number 355000106092802 (fig. $2 A$ ) was completed to a depth of $840 \mathrm{ft}$ in the Santa Fe Group aquifer system and began recording groundwater-level altitudes in 1986 (U.S. Geological Survey, 2017). The largest groundwaterlevel decline in this well since installation was nearly $380 \mathrm{ft}$ in 2000, but groundwater levels have since recovered to their highest altitudes for the period of record. Hydrographs from the Buckman well field when wells were not pumping show that the greatest declines in groundwater-level altitudes were during 1999-2000; wells 1 to 8 (fig. $2 A$ inset) show declines of more than $400 \mathrm{ft}$ in that period (Houston and others, 2020). Groundwater-level altitudes in wells 1, 2, 7, and 8 have returned to altitudes similar to or above those observed at the start of the period of record (1986); however, as of 2019, wells $3,4,5$, and 6 continued to exhibit groundwater level deficits between 35 and $80 \mathrm{ft}$ relative to 1986 . Groundwater level-change maps developed for this study show comparable groundwater-level declines in this area, with large declines around the well field between each 5-year period from 1980 to 2000 and large recoveries after 2000, which corresponds with the implementation of comprehensive water conservation efforts and increased use of surface water diversions to help meet the municipal demands in Santa Fe (figs. 21-24). 


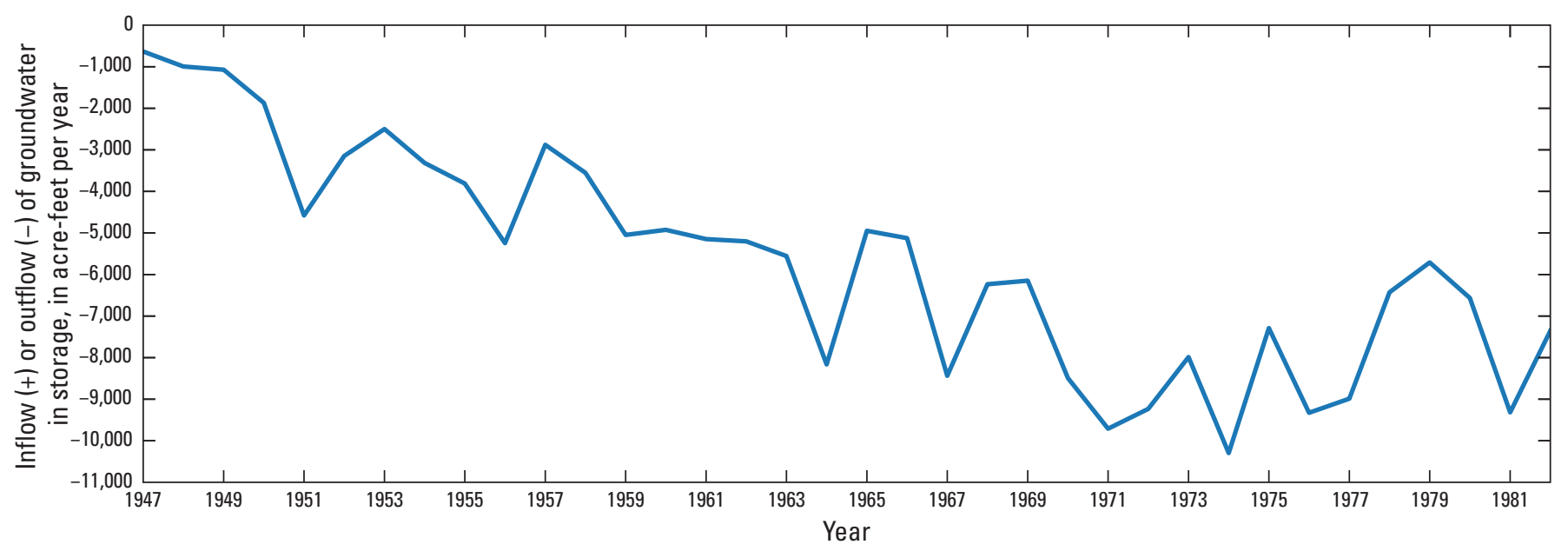

Figure 26. Graph showing simulated annual outflows from groundwater storage in the Tesuque aquifer in the Española Basin for the McAda and Wasiolek (1988) groundwater-flow model.

\section{Middle Rio Grande Alluvial Basin}

Within the Middle Rio Grande alluvial basin, there were 43 or more wells with measurements during consecutive 5-year periods (table 3). Median groundwater-level changes measured in individual wells declined during each 5-year period from 1980 to 2005 (table 3). The largest decline in groundwater-level altitude of approximately $61 \mathrm{ft}$ was during 2000-05, and the largest rise of approximately $172 \mathrm{ft}$ was observed during 1995-2000 (table 3). For the entire study period, the largest decline in groundwater-level altitudes was approximately $65 \mathrm{ft}$, and the largest rise was approximately $30 \mathrm{ft}$.

Wells with groundwater-level measurements for at least 50 percent of the 5 -year periods from 1980 to 2015 were clustered around the greater Albuquerque area (fig. 12). Although considered essentially stable, the median rate of change for five-year medians in the Middle Rio Grande alluvial basin declined by $-0.01 \mathrm{ft}$ per 5 -year period during the study period (table 2), with flat (less than $0.1 \mathrm{ft}$ rise or decline) linearregression slopes in 34 percent of wells, negative linearregression slopes in 34 percent of wells, and positive linearregression slopes in 31 percent of wells.

The Middle Rio Grande regional water plan (New Mexico Office of the State Engineer, 2017) discussed the effects of the San Juan-Chama Project, which was designed to supplement groundwater withdrawals by an interbasin diversion of some of New Mexico's allocated surface water from the San Juan River into the Rio Chama. The water plan stated that, although some areas with monitoring wells near old production wells in the Middle Rio Grande alluvial basin have exhibited groundwater-level rises (figs. 27-29) since withdrawals in some areas have been replaced by the San Juan-Chama Project in 2010, other areas continue to exhibit groundwater-level declines. Similarly, the groundwater-level change map for 2010-15 shows localized areas with groundwater-level altitude rises and declines near Albuquerque (fig. 30A). Groundwater-level change maps show larger areas of groundwater declines in the earlier periods of the study (1980-2005) along the boundaries of the mapped extents and smaller areas of declines near the Rio Grande (figs. 27, 28, and 29A). Overall, the groundwater-level change map for the entire study period shows the largest decline around Albuquerque and Algodones, N. Mex., with smaller declines along the Rio Grande (fig. 30B). Falk and others (2011) stated that groundwater-level changes from predevelopment to 2008 are variable across the Middle Rio Grande alluvial basin, with the smallest changes observed to the southwest and along the Rio Grande, and the largest changes observed east of Albuquerque.

Storage changes for the Middle Rio Grande alluvial basin were estimated for an area of approximately $511 \mathrm{mi}^{2}$, or 17 percent of basin (fig. 3). Changes in storage were based on specific yield estimates of 0.12 to 0.20 (Kernodle and others, 1995; Tiedeman and others, 1998; Barroll, 2001; McAda and Barroll, 2002; S.S. Papadopulos \& Associates, 2006; Bexfield and others, 2011; Heywood, 2013). Smaller specific yield values contribute to more subdued changes, and larger specific yield values contribute to larger changes in storage. In most of the 5-year periods, with the exceptions of 1980-85, 2000-05, and $2010-15$, the amount of groundwater in storage decreased (fig. 31).

The McAda and Barroll (2002) model (1900-2000) was updated by Bexfield and others (2011) to simulate groundwater conditions in the Middle Rio Grande alluvial basin during 1900-2008 (fig. 3), using a specific yield value of 0.20 uniformly throughout the modeled area. Storage reductions in the Middle Rio Grande alluvial basin began in the mid-1950s and have continued ever since, except for a brief period of recovery (or reductions in storage outflows) in the mid-1980s, as seen in simulated outflows of groundwater from storage (fig. 32). The simulated storage results and storage 


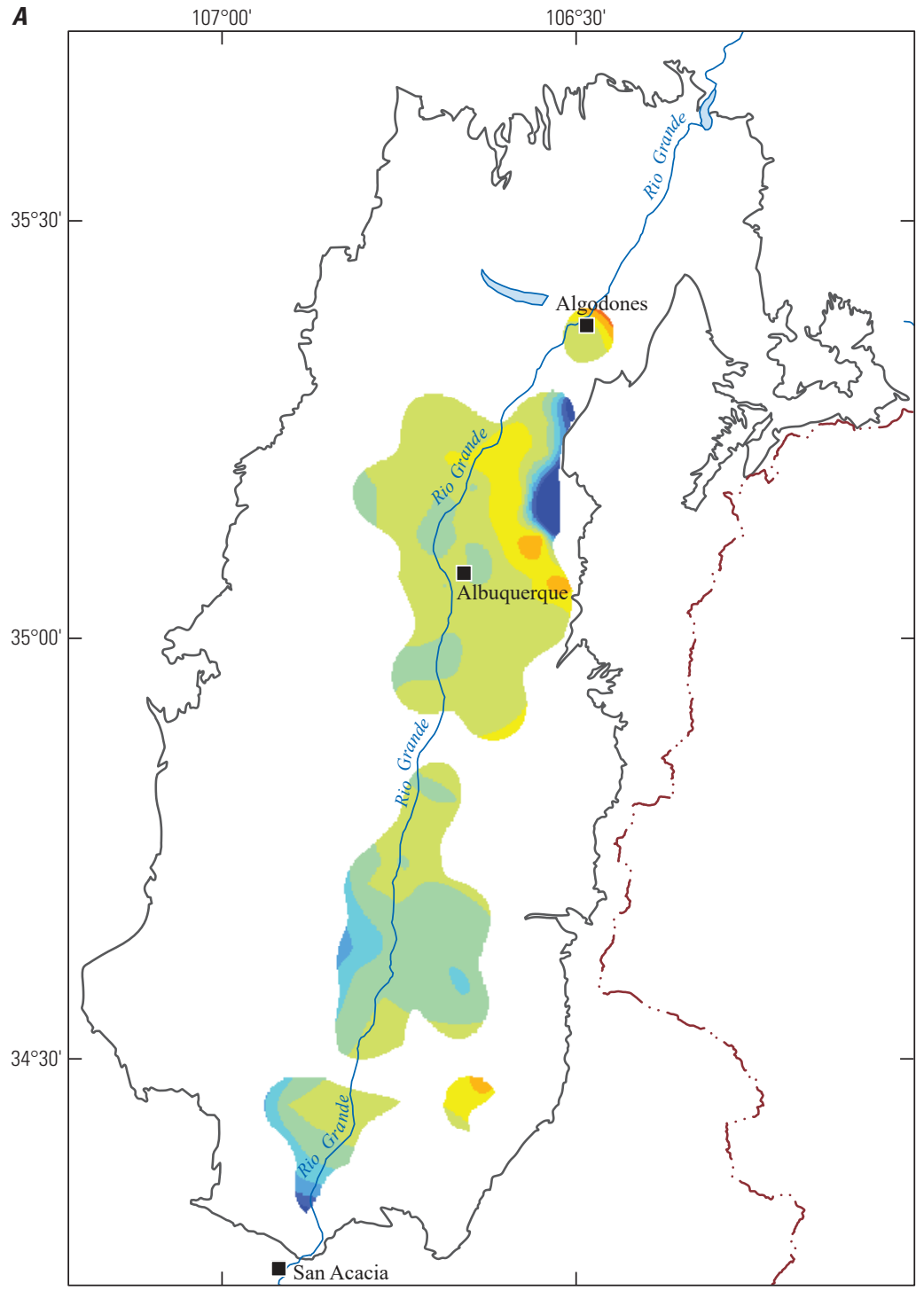

Base modified from U.S. Census Bureau digital data, 1:500,000, 2015 Universal Transverse Mercator, zone 13 North American Datum of 1983

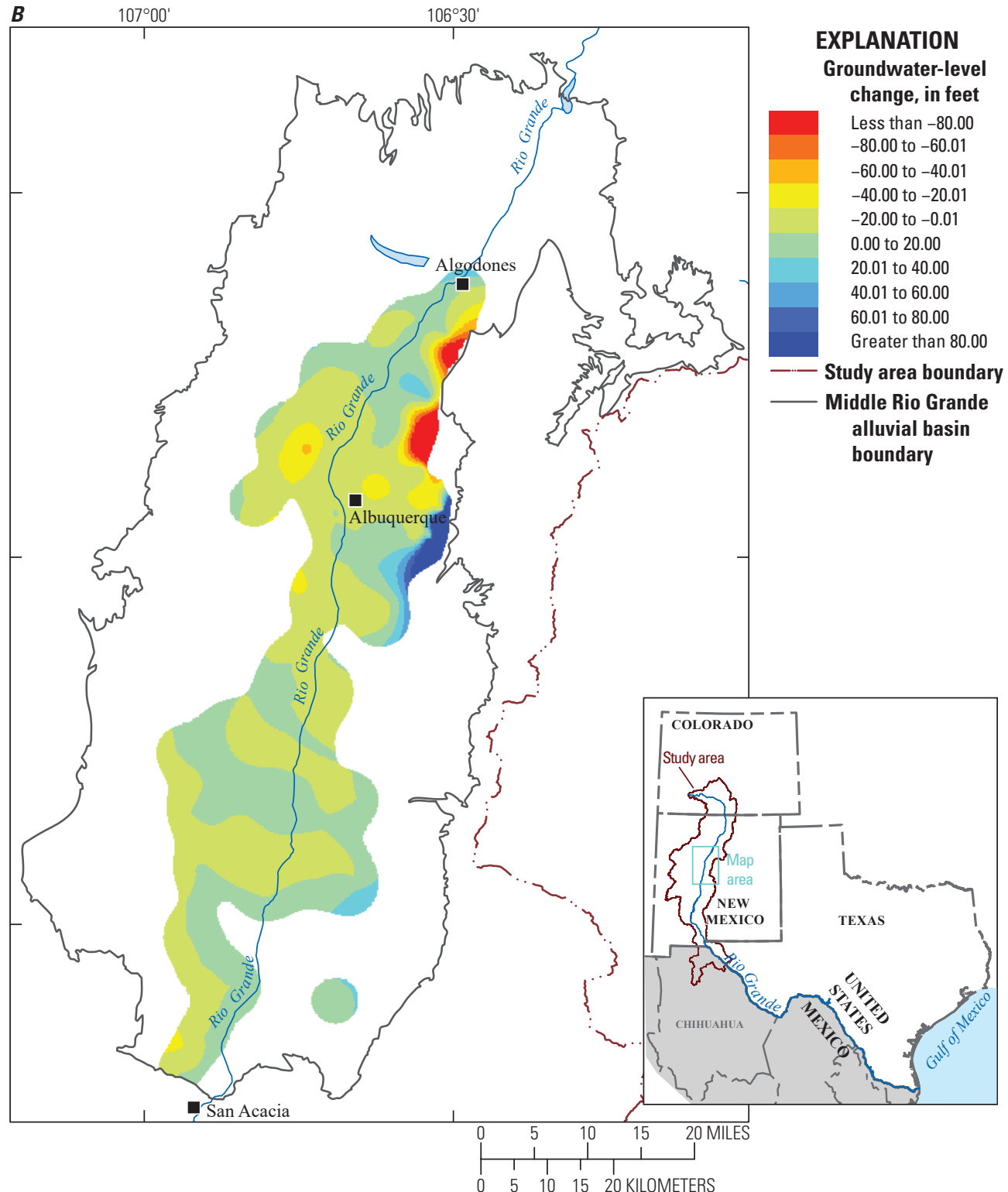

Figure 27. Maps showing median groundwater-level changes for the Middle Rio Grande alluvial basin during $A, 1980-85$ and $B$, 1985-90 in New Mexico. 


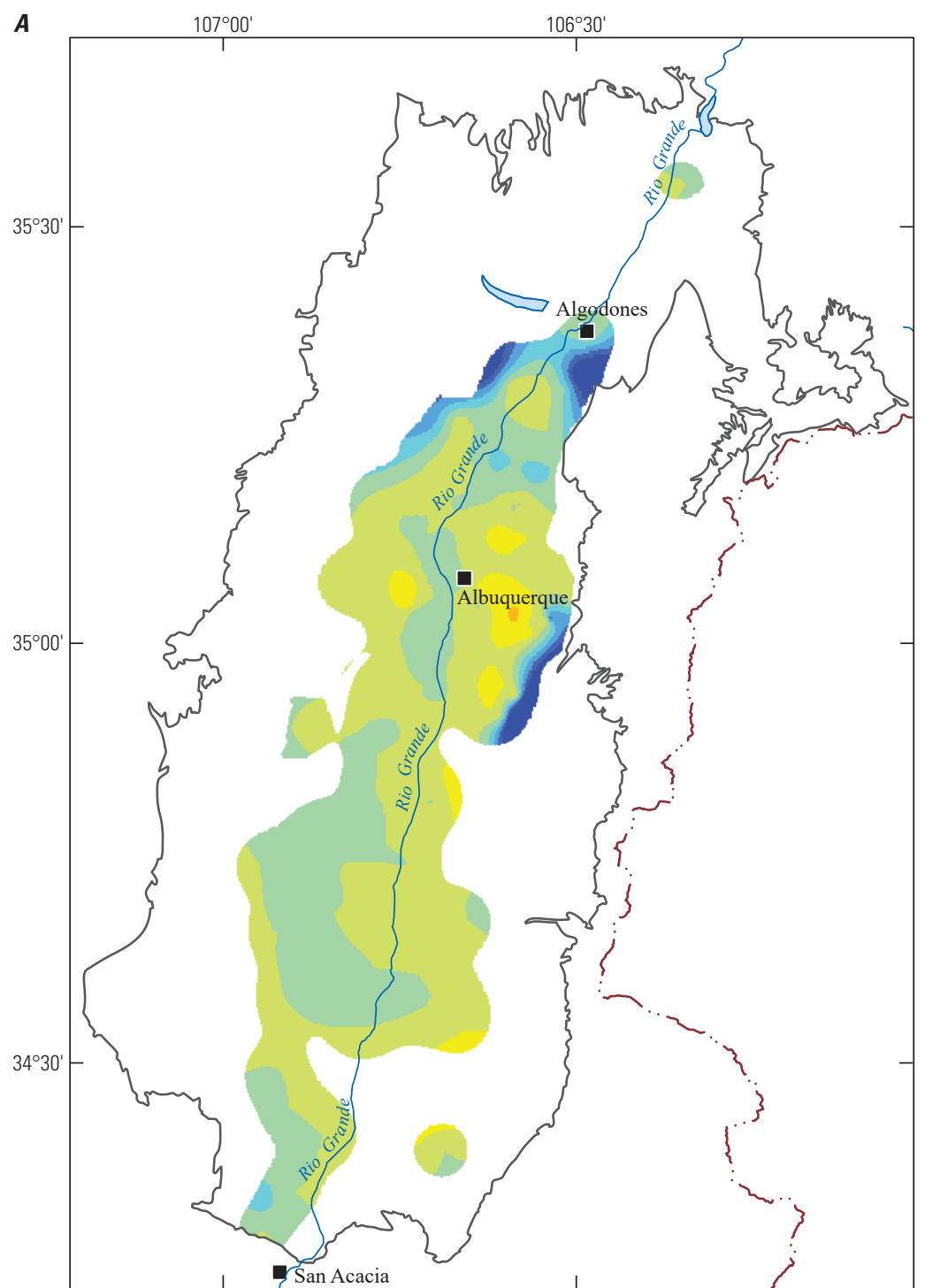

Base modified from U.S. Census Bureau digital data, 1:500,000, 2015 Universal Transverse Mercator, zone 13 North American Datum of 1983

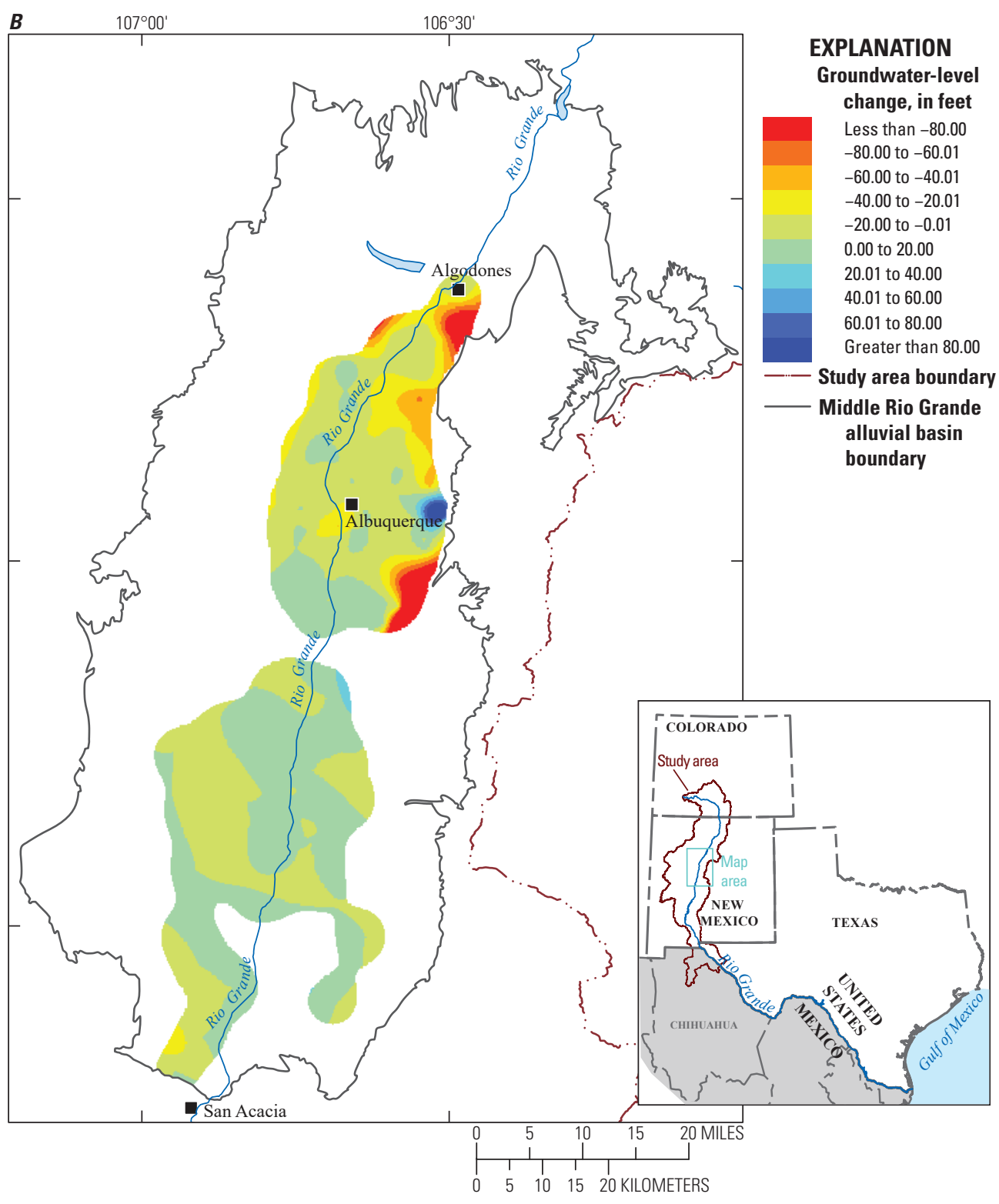

Figure 28. Maps showing median groundwater-level changes for the Middle Rio Grande alluvial basin during $A, 1990-95$ and $B, 1995-2000$ in New Mexico.
怘

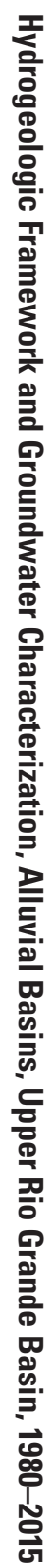




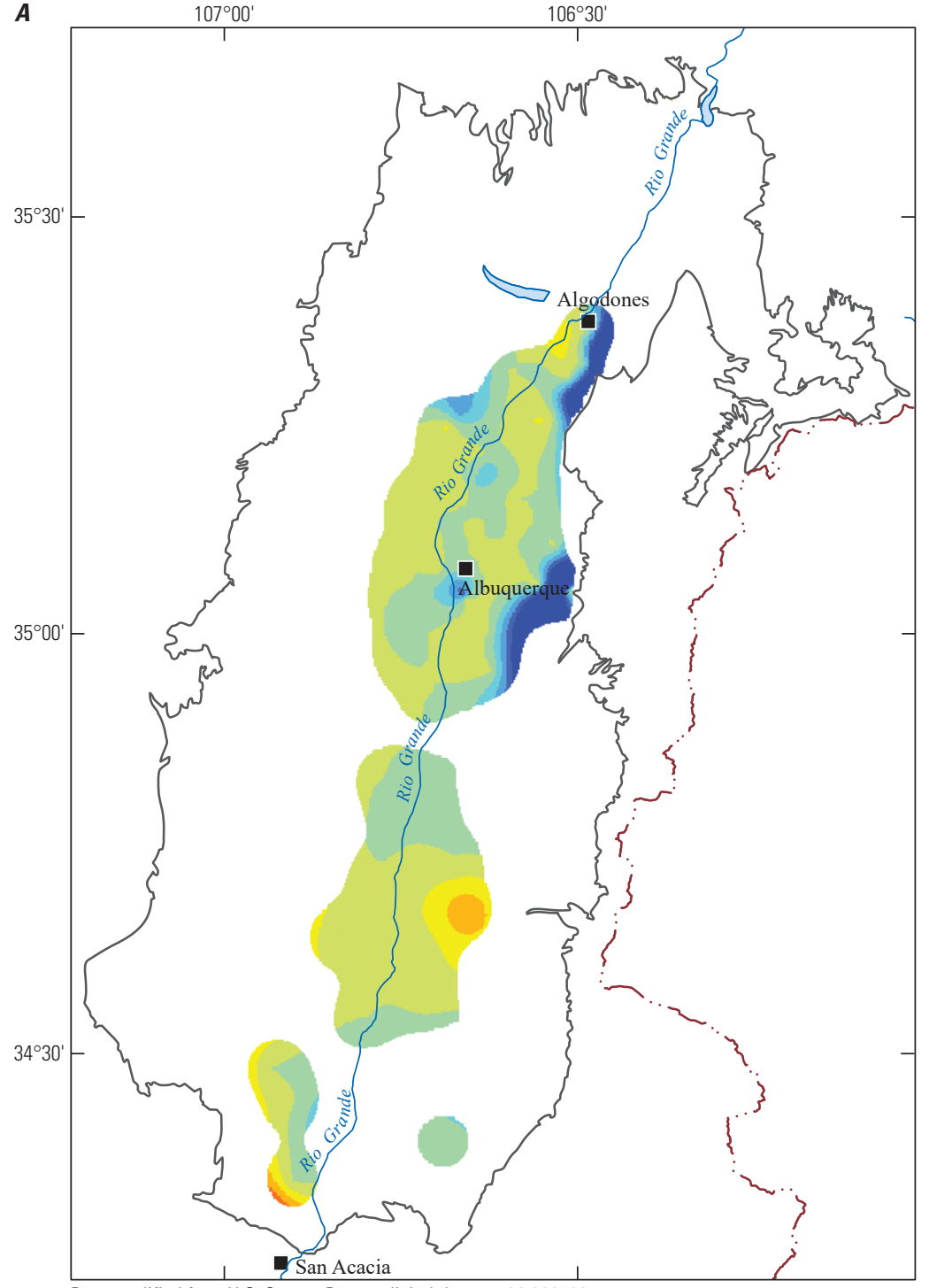

Base modified from U.S. Census Bureau digital data, 1:500,000, 2015 Universal Transverse Mercator, zone 13 North American Datum of 1983

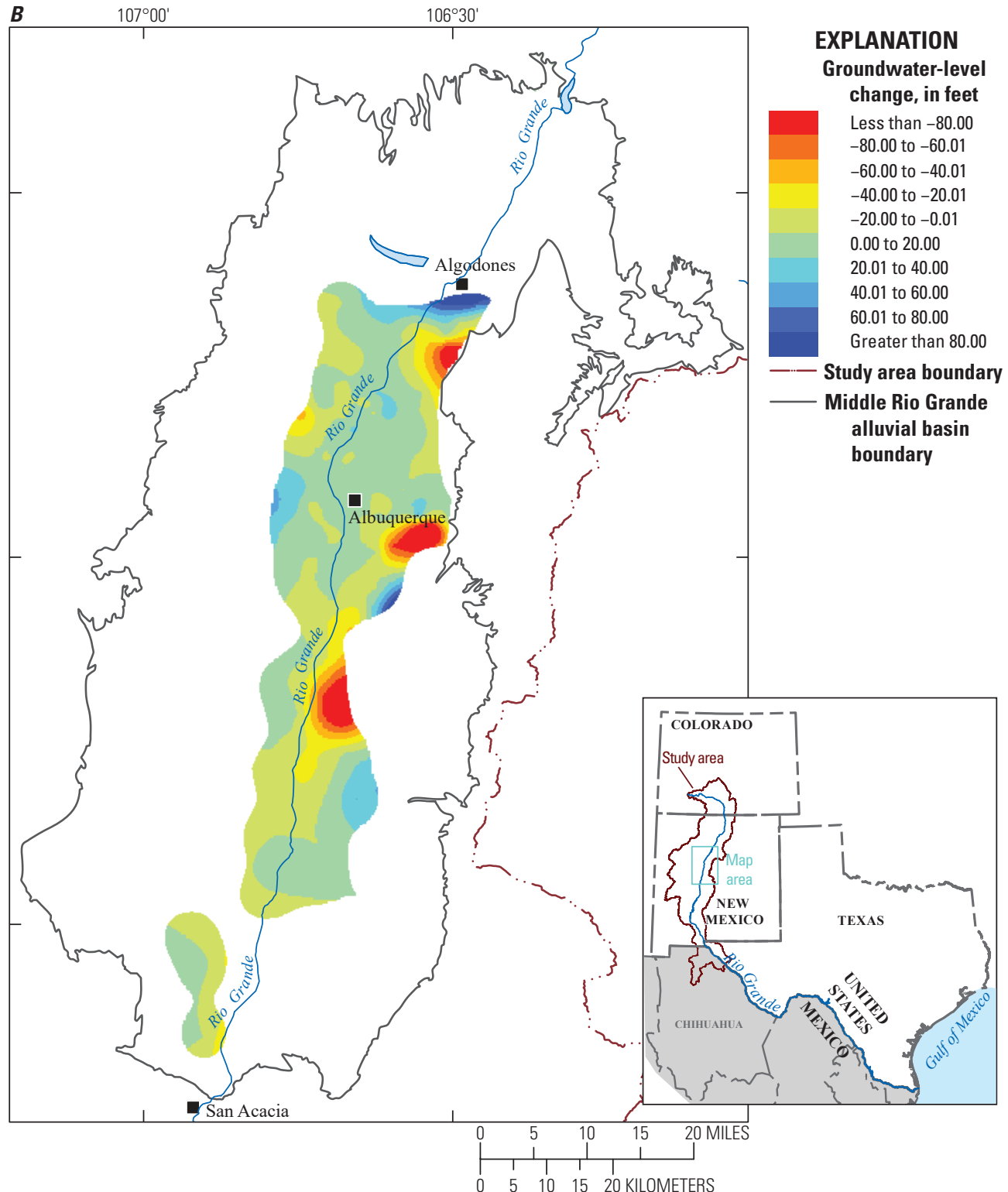

Figure 29. Maps showing median groundwater-level changes for the Middle Rio Grande alluvial basin during A, 2000-05 and B, 2005-10 in New Mexico. 

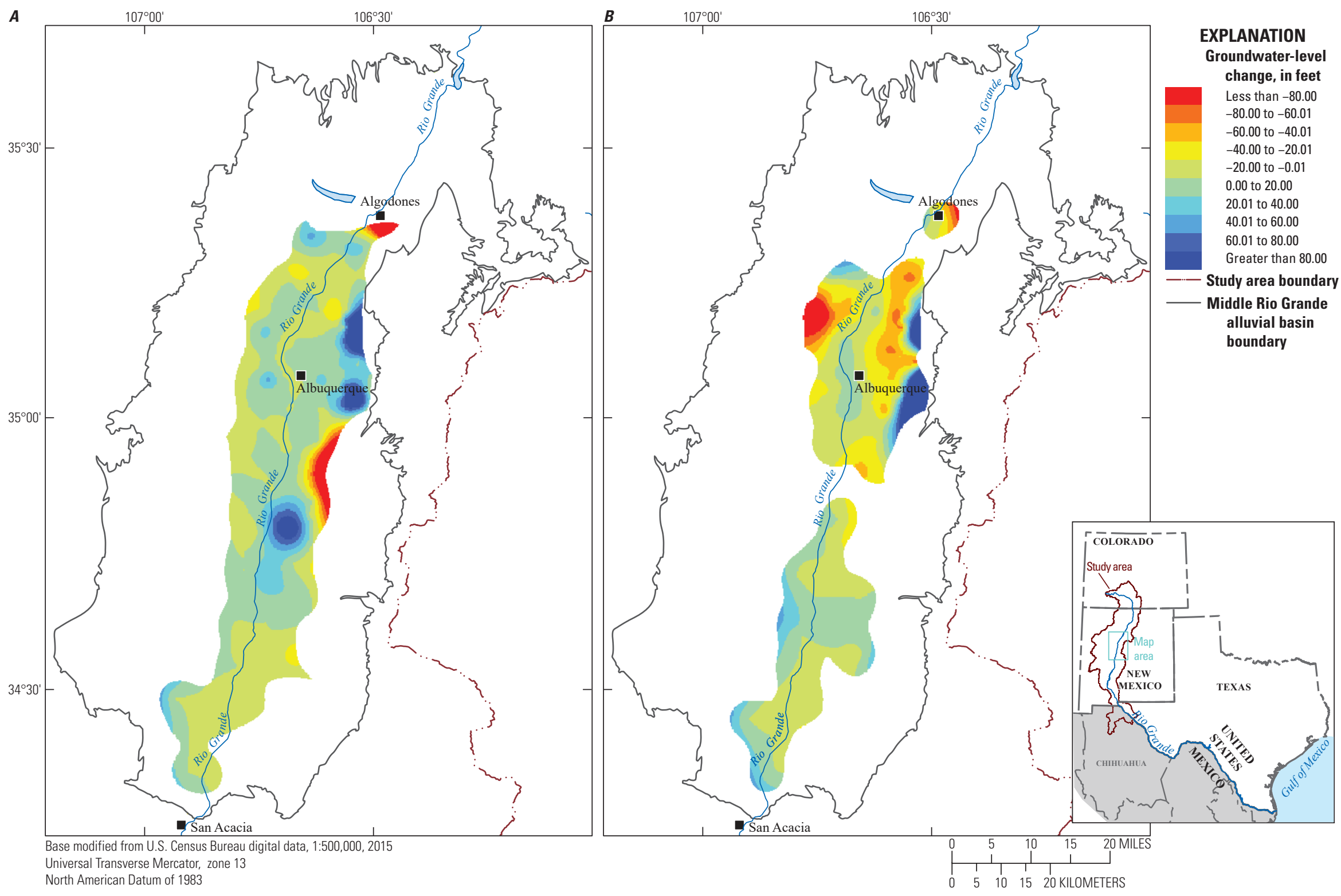

Figure 30. Maps showing median groundwater-level changes for the Middle Rio Grande alluvial basin during $A, 2010-15$ and $B, 1980-2015$ New Mexico. 


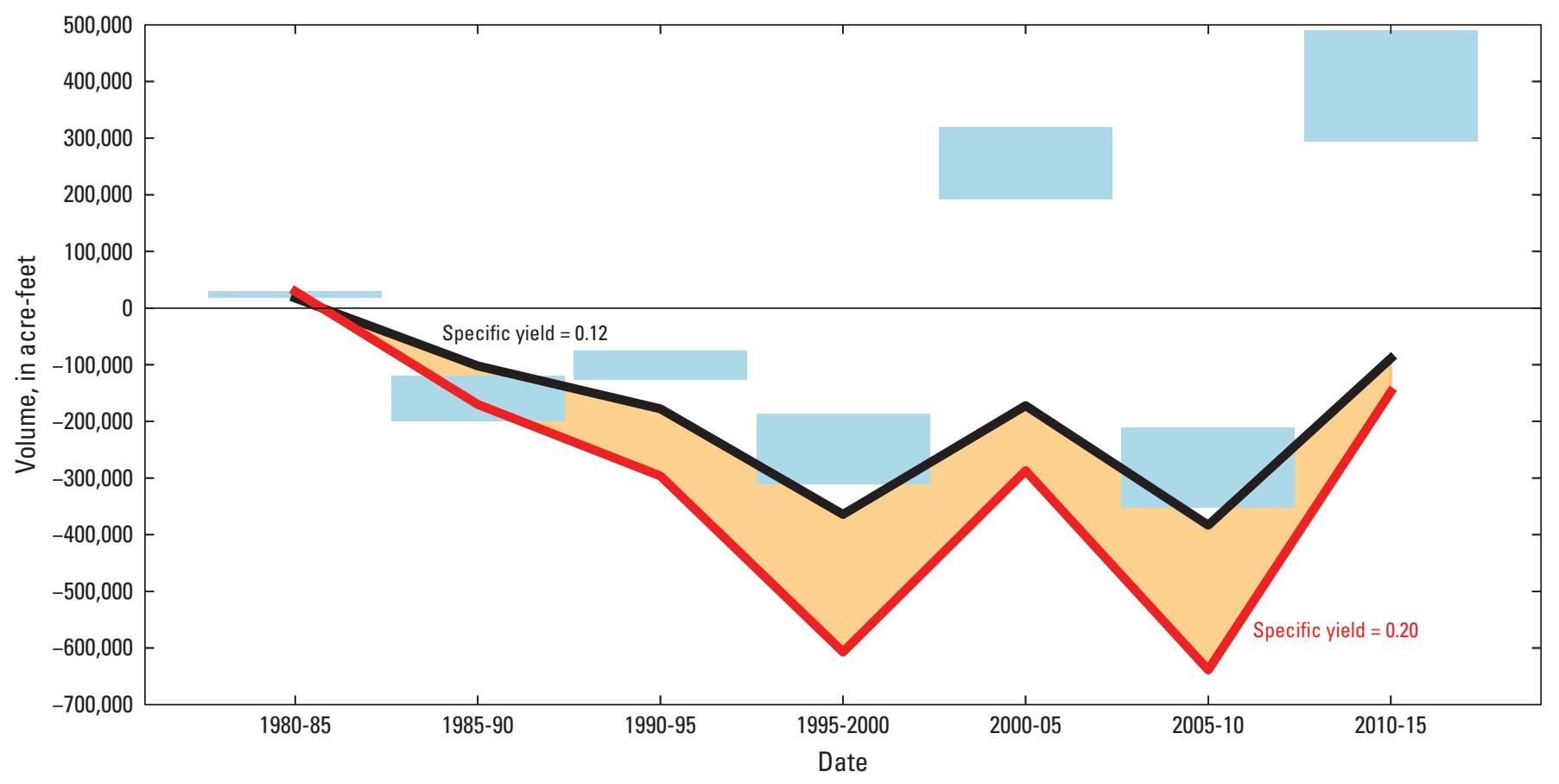

Figure 31. Graph showing ranges of groundwater-storage changes for the Middle Rio Grande alluvial basin for 5-year periods (blue) and cumulative storage change from 1980 to 2015 (red); the black line represents cumulative storage change using specific yield of 0.12 and the red line represents cumulative storage change using specific yield of 0.20 . Blue bars represent the range of storage volume change with one end representing the lower value of specific yield and the other end representing the upper value of specific yield.

results from groundwater-level altitudes cover different parts and different depths of the study area of the Middle Rio Grande alluvial basin (fig. 3). The Bexfield and others (2011) groundwater-flow model simulates thicknesses of unconfined and semiconfined units of as much as nearly $15,000 \mathrm{ft}$ thick, whereas the deepest well used in the storage computations from groundwater-level changes is $935 \mathrm{ft}$ deep, with mean well depths of about $185 \mathrm{ft}$.

Even though the study areas used by McAda and Barroll (2002) and Bexfield and others (2011) are different, the rate of outflow of groundwater from storage slows during the early 1980 s, as seen in the results from the Bexfield and others (2011) groundwater-flow model (fig. 32), which corresponds with the positive change in storage during 1980-85 as seen in the groundwater-level altitude results (fig. 31). A similar comparison was seen in the results with a reduction in storage from 1985 to 2000. Ritchie and others (2019) describe how groundwater-level altitudes are beginning to show a recovery of about 20 to $30 \mathrm{ft}$ following the addition of surface water to the distribution system of the Albuquerque Bernalillo County Water Utility Authority from the San Juan-Chama diversion starting in 2008. The timing associated with the incorporation of the additional source water from the Colorado River Basin corresponds with increases in cumulative storage after 2008 (fig. 31) and localized rises in groundwater-level altitudes (figs. 28, 29, and 30A) near Albuquerque. 


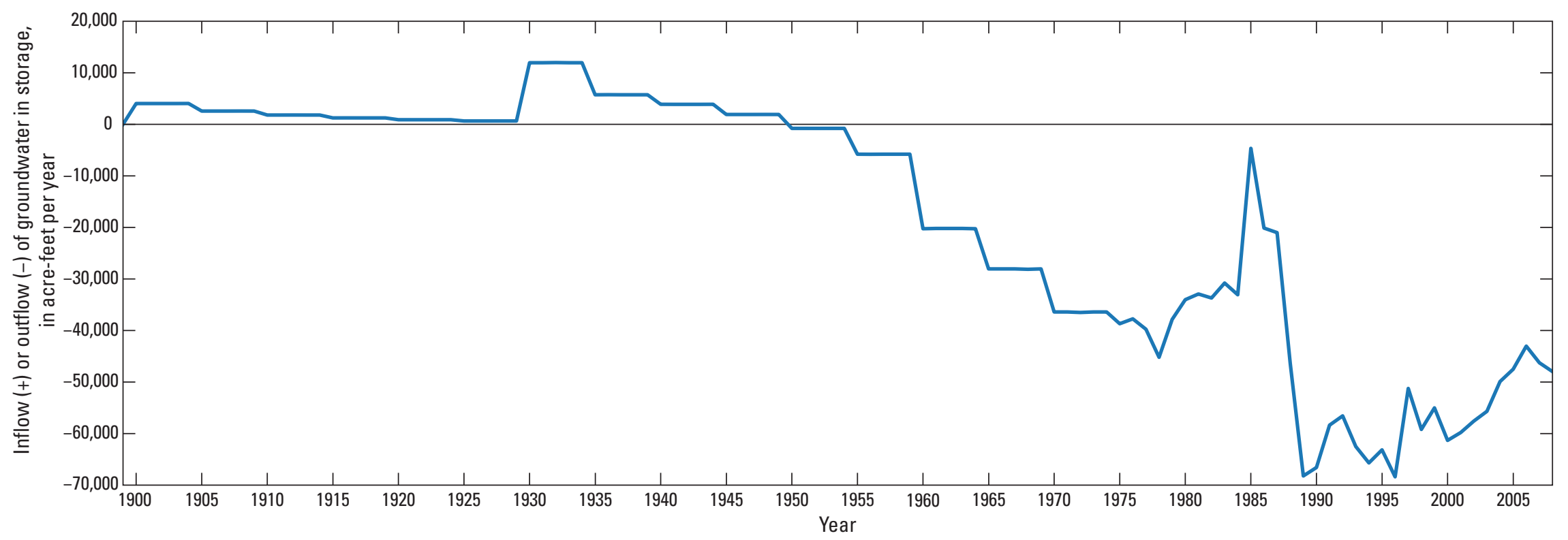

Figure 32. Graph showing simulated inflows to and outflows from groundwater in storage by model stress period (of variable length) from 1900 to 2009 in the Santa Fe Group aquifer system in the Middle Rio Grande alluvial basin for the Bexfield and others (2011) groundwater-flow model. The data before 1900 represent the predevelopment (steady-state) period before the start of the transient model. 


\section{San Agustin Alluvial Basin}

During 1980-90 and 2000-10, there were no wells with groundwater-level measurements for consecutive 5-year periods measured in the San Agustin alluvial basin. For 5-year periods that have groundwater-level measurements in wells for consecutive time periods, the largest decline of approximately $13 \mathrm{ft}$ was observed during 1990-95, and during the entire study period, a maximum groundwater-level altitude decline of approximately $34 \mathrm{ft}$ was observed at a single well. The largest rise in groundwater-level altitude observed in a single well for 5-year time periods was approximately $14 \mathrm{ft}$ during 1995-2000. For the entire study period, no rises in groundwater-level altitudes in individual wells were observed in the San Agustin alluvial basin wells (table 3).

There are 23 wells distributed relatively evenly throughout the part of the San Agustin alluvial basin west of the Gallinas Mountains from which groundwater-level measurements were collected during 50 percent or more of the study period. The median slopes of 5-year median groundwater-level altitudes in the San Agustin alluvial basin are essentially stable from 1980 to 2015 (table 2). The linear-regression slopes of the best-fit line to the medians was relatively flat for 83 percent of the wells in the basin (fig. 12).

The compiled groundwater-level data for the San Agustin alluvial basin were insufficient to develop groundwaterlevel altitude grids for the 5-year periods from 1985 to 2005 . Storage changes could not be computed for the San Agustin alluvial basin because of insufficient data coverage for the study period.

\section{Socorro Alluvial Basin}

Although the Socorro alluvial basin has wells that have measurements in consecutive 5-year periods for each period after 1980-85, each period has 11 or fewer wells. The largest decline in groundwater-level altitudes for these wells in the Socorro alluvial basin was approximately $6 \mathrm{ft}$ during 2010-15, and the largest rise was approximately $18 \mathrm{ft}$ during 1990-95 (table 3). Only one well had data available from 1980 to 2015, and it had a decline in groundwater-level altitude of approximately $61 \mathrm{ft}$. The compiled groundwater-level data for the Socorro alluvial basin were insufficient for developing groundwater-level altitude grids for 2000-05. Storage changes could not be computed for the Socorro alluvial basin because of insufficient data coverage for the study period.

\section{La Jencia Alluvial Basin}

Groundwater-level data for the La Jencia alluvial basin are of limited availability. Only two wells have groundwaterlevel measurements for consecutive periods for 2010-15 (table 3) During 2010-15, there was a maximum decline in groundwater-level altitudes of approximately $7 \mathrm{ft}$ and no rises. No wells had groundwater-level measurements representing 50 percent or more of the 5 -year increments representing by the study period, and therefore the compiled median groundwater-level measurements were insufficient to evaluate groundwater-level change. Storage changes could not be computed for the La Jencia alluvial basin because of insufficient data coverage for the study period.

\section{San Marcial Alluvial Basin}

Similar to the La Jencia alluvial basin, there are limited groundwater-level data available for the San Marcial alluvial basin, and most periods have fewer than 5 wells with measurements for consecutive periods. The largest decline in groundwater-level altitudes in wells with measurements in consecutive periods was about $8 \mathrm{ft}$ observed during 1990-95, and the largest rise was about $13 \mathrm{ft}$ during 2010-15 (table 3). There are no individual wells with groundwater-level altitude measurements for both the 1980 and 20155 -year periods. Groundwater-level measurements were collected from four wells in the San Marcial alluvial basin during 50 percent or more of the study period (table 2). With only one complete record of groundwater-level altitudes and large gaps in data collection records for the remaining wells, the compiled median groundwater-level measurements were insufficient to evaluate groundwater-level change. The compiled groundwater-level data for the San Marcial alluvial basin were insufficient for the development of groundwater-level altitude grids for the 1990-95, 1995-2000, and 2000-05 periods. Storage changes could not be computed for the San Marcial alluvial basin because of insufficient data coverage for the study period.

\section{Alamosa Creek Alluvial Basin}

The Alamosa Creek alluvial basin only had groundwaterlevel data for consecutive 5-year periods for the 1990-95 and $2010-15$ periods. For wells with measurements during consecutive 5-year periods, the largest decline (6 ft) and largest rise $(0.6 \mathrm{ft})$ in groundwater-level altitudes were observed during 2010-15. For the entire study period, the largest decline in the two wells with groundwater measurements in the two 5-year periods was approximately $0.1 \mathrm{ft}$, and the largest rise was approximately $3 \mathrm{ft}$. There were insufficient data to compute a median slope for the Alamosa Creek alluvial basin (table 2). The compiled groundwater-level data for the Alamosa Creek alluvial basin were insufficient for developing groundwaterlevel altitude grids for the 1985-85, 1995-2000, 2000-05, and 2005-10 periods. Storage changes could not be computed for the Alamosa Creek alluvial basin because of insufficient data coverage for the study period. 


\section{Engle Alluvial Basin}

Groundwater in the Engle alluvial basin is used in Truth or Consequences for domestic and agriculture purposes. Truth or Consequences is considered a resort town and has numerous hot springs from geothermal sources. Other than areas near the towns of Truth or Consequences, Elephant Butte, and Williamsburg in the southern side of the basin and Monticello in the northwest, there is very little development in the Engle Basin. Although wells are spatially distributed evenly throughout the Engle alluvial basin, wells typically only have measurements for one 5-year period. Within the Engle alluvial basin, there are only three date ranges with more than one well that have consecutive 5-year measurements (1985-90, 1990-95, and 2010-15). The largest decline in groundwaterlevel altitudes observed at wells with measurements in consecutive 5-year period was about $8 \mathrm{ft}$ during 2010-15, and the largest rise was about $28 \mathrm{ft}$ during 1985-90 (table 3). The groundwater-level altitude rose by about $3 \mathrm{ft}$ in the only well with groundwater-level measurements in both the 1980 and 2015 5-year periods. Because median groundwater-level measurements for 50 percent or more of the 5-year periods were only available from seven wells, the compiled median groundwater-level measurements were insufficient to evaluate groundwater-level change. The compiled groundwater-level data for the Engle alluvial basin were insufficient for developing groundwater-level altitude grids for the 2000 5-year period. Storage changes could not be computed for the Engle alluvial basin because of insufficient data coverage for the study period.

\section{Palomas Alluvial Basin}

In the Palomas alluvial basin, groundwater-level measurements were made at 29 or more wells with measurements in consecutive 5-year periods (table 3 ). The groundwater-level altitude data indicated that, in individual wells, the maximum groundwater-level altitude decline was about $87 \mathrm{ft}$ during 2010-15, and the largest rise was about $64 \mathrm{ft}$ during 1980-85. The largest groundwater-level altitude decline was about $20 \mathrm{ft}$, and the largest rise, about $107 \mathrm{ft}$ for the 18 individual wells with measurements in both 1980 and 2015 5-year periods (table 3). Median values for 5-year change in groundwaterlevel altitudes for wells with measurements in consecutive 5 -year periods range from declines of about $1.8 \mathrm{ft}$ to rises of about $1.5 \mathrm{ft}$, with declines during four of the seven 5-year change periods from 1980 to 2015. Median groundwater-level altitudes in the Palomas alluvial basin declined by $0.1 \mathrm{ft}$ per 5 -year period for wells from which groundwater-level measurements were collected during 50 percent or more of the 5-year periods from 1980 to 2015 (table 2). Groundwater-level declines were observed in 49 percent of the wells, and no change was observed in 38 percent of the wells (fig. 12).
Storage changes for the Palomas alluvial basin were estimated for an area of approximately $325 \mathrm{mi}^{2}$ (37 percent of basin; fig. 3). Changes in storage were based on specific yield estimates of 0.07 to 0.25 (Weeden and Maddock, 1999; Hanson and others, 2020). Smaller specific yield values contribute to more subdued changes, whereas larger specificyield values contribute to larger changes in storage. Using the information from previously published groundwater models, during 1980-90, 1995-2000, and 2005-10, the amount of groundwater in storage increased, but similar to the amount of storage computed by using median groundwater levels, cumulative storage remained comparable in 2015 relative to 1985 (fig. 33). A groundwater-flow model developed for the Rincon Valley within the Palomas alluvial basin simulated changes in storage (Hanson and others, 2020). The results from this model, which included the Rincon Valley and the Palomas alluvial basin within its much larger study area, are discussed in the "Mesilla/Conejos-Médanos Alluvial Basin" section of this report.

The southern part of the Palomas alluvial basin contains the Rincon Valley where Hatch is located. Crops grown in the Rincon Valley near Hatch include chiles, cotton, onions, and pecans (Driscoll and Sherson, 2016). Groundwater-level measurements in the Palomas alluvial basin are clustered along the Rio Grande from about $17 \mathrm{mi}$ upstream to about $12 \mathrm{mi}$ downstream from Hatch, which corresponds to the agricultural region of the Rincon Valley (fig. 2B). The Natural Resources Conservation Service reported that, in each annual growing season during periods when the Rio Grande flows through the Rincon Valley, wells in the region generally showed a short initial rise in groundwater-level altitudes which may be caused by the use of surface water from the Rio Grande to irrigate crops, reduced groundwater withdrawals, and water from the Rio Grande seeping into the groundwater system (Stringam and others, 2016). The initial rises in groundwaterlevel altitudes are followed by declines in groundwater-level altitudes once groundwater withdrawals resume. These cycles of rising then declining groundwater-level altitudes are highly variable from year to year because the annual releases from the Caballo Dam during the irrigation season vary depending on the amount of winter snowpack in Colorado and northern New Mexico.

\section{Jornada del Muerto Alluvial Basin}

The largest groundwater-level altitude declines at individual wells were about 39 and $40 \mathrm{ft}$ during 1990-95 and 2005-10, respectively (table 3). The largest rises in groundwater-level altitudes were about 84 and $71 \mathrm{ft}$ during 1985-90 and 2005-10, respectively. Median groundwaterlevel altitudes in the Jornada del Muerto alluvial basin were relatively stable (less than $0.1 \mathrm{ft}$ of rise or decline) for wells from which groundwater-level measurements were collected during 50 percent or more of the 5-year periods from 1980 to 2015 (table 2). Groundwater-level declines were observed in 


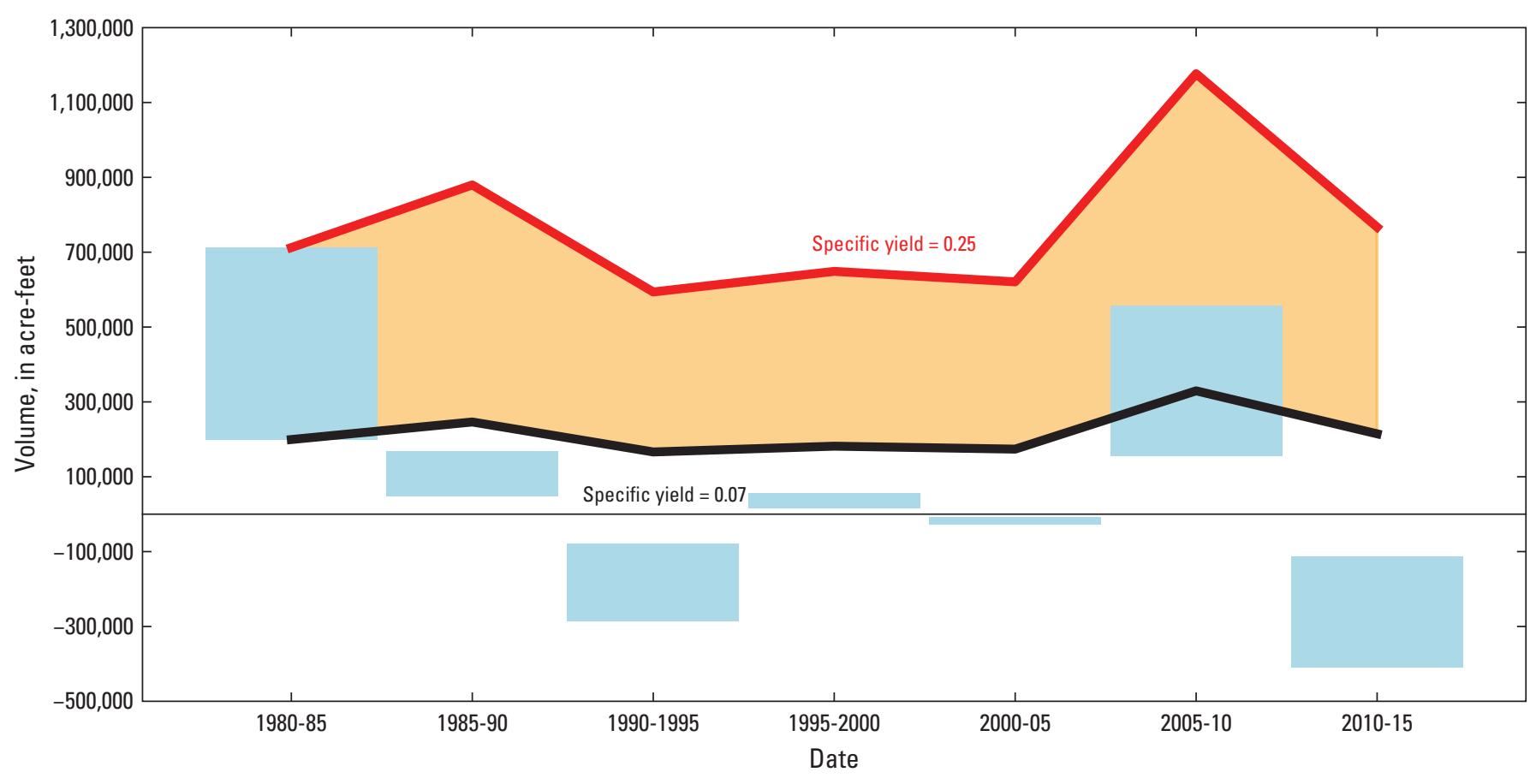

Figure 33. Graph showing ranges of groundwater-storage changes for the Palomas alluvial basin for 5-year periods (blue) and cumulative storage change from 1980 to 2015 (red); the black line represents cumulative storage change using specific yield of 0.07 and the red line represents cumulative storage change using specific yield of 0.25 . Blue bars represent the range of storage volume change with one end representing the lower value of specific yield and the other end representing the upper value of specific yield.

43 percent of the wells, and rises were observed in 29 percent of the wells. Most of the 21 wells with groundwater-level measurements available for 50 percent or more of the study period are in the western half of the basin, primarily south of the Caballo Reservoir (fig. 2B). There are also a few wells with multiple measurement in the northern part of the basin. Storage changes could not be computed for the Jornada del Muerto alluvial basin because data coverage for the alluvial basin was less than 10 percent.

\section{Mesilla/Conejos-Médanos Alluvial Basin}

Among the 13 alluvial basins discussed in this report, the Mesilla/Conejos-Médanos alluvial basin had the most wells with groundwater-level measurements in consecutive 5-year periods, with groundwater-level data from at least 107 wells in each 5-year period (table 3). The largest decline of groundwater-level altitudes at individual wells was about $28 \mathrm{ft}$ during 1980-85, and the largest rise was about $188 \mathrm{ft}$, which was also during 1980-85. For the entire study period, 40 wells have measurements in both 1980 and 2015, the maximum decline measured in these wells was about $17 \mathrm{ft}$, and the maximum rise was about $50 \mathrm{ft}$. The median 5-year change in individual wells were declines after 1995. Groundwater-level change maps developed for this study show localized areas of declines in the area east of the Doña Ana Mountains and small localized rises in the north-central parts of the basin (figs. 34-37). Because of drought conditions in 2004, surface-water releases from the Elephant Butte Dam were reduced, and supplemental groundwater use for irrigation needs rose to more than $154,000 \mathrm{ac}-\mathrm{ft} / \mathrm{yr}\left(190 \mathrm{Mm}^{3} / \mathrm{yr}\right)$, more than

double the long-term mean of about 70,000 ac-ft/yr (86.3 $\mathrm{Mm}^{3} / \mathrm{yr}$; Sheng, 2013). In 2010, Ciudad Juárez started pumping groundwater from its well field that is hydraulically connected to the Mesilla/Conejos-Médanos alluvial basin (Sheng, 2013), which coincides with areas of groundwaterlevel altitude declines to the west of Ciudad Juárez from 2005 to 2010 (fig. $36 B$ ). Changes in storage can vary considerably from year to year, depending on land use, groundwater withdrawals, and climate conditions (Hanson and others, 2020).

Median groundwater-level altitudes in the Mesilla/ Conejos-Médanos alluvial basin declined by a median rate of $0.10 \mathrm{ft}$ per 5 -year period for the 169 wells from which groundwater-level measurements were collected during 50 percent or more of the 5-year periods from 1980 to 2015 (table 2). Groundwater-level altitudes declined in 51 percent of these 169 wells, and 43 percent of wells had little to no change during the study period. Most of the wells included in the linear regression slope analysis are distributed along the Rio Grande in the Mesilla/Conejos-Médanos alluvial basin. Multiple groundwater level studies in the Mesilla/ConejosMédanos alluvial basin found that trends in groundwater-level changes vary for different layers (alluvium, upper, middle, or lower Santa Fe Group) and that groundwater-level data in the alluvium are more variable and relatively scarce compared with the deeper units (Sheng, 2013). 


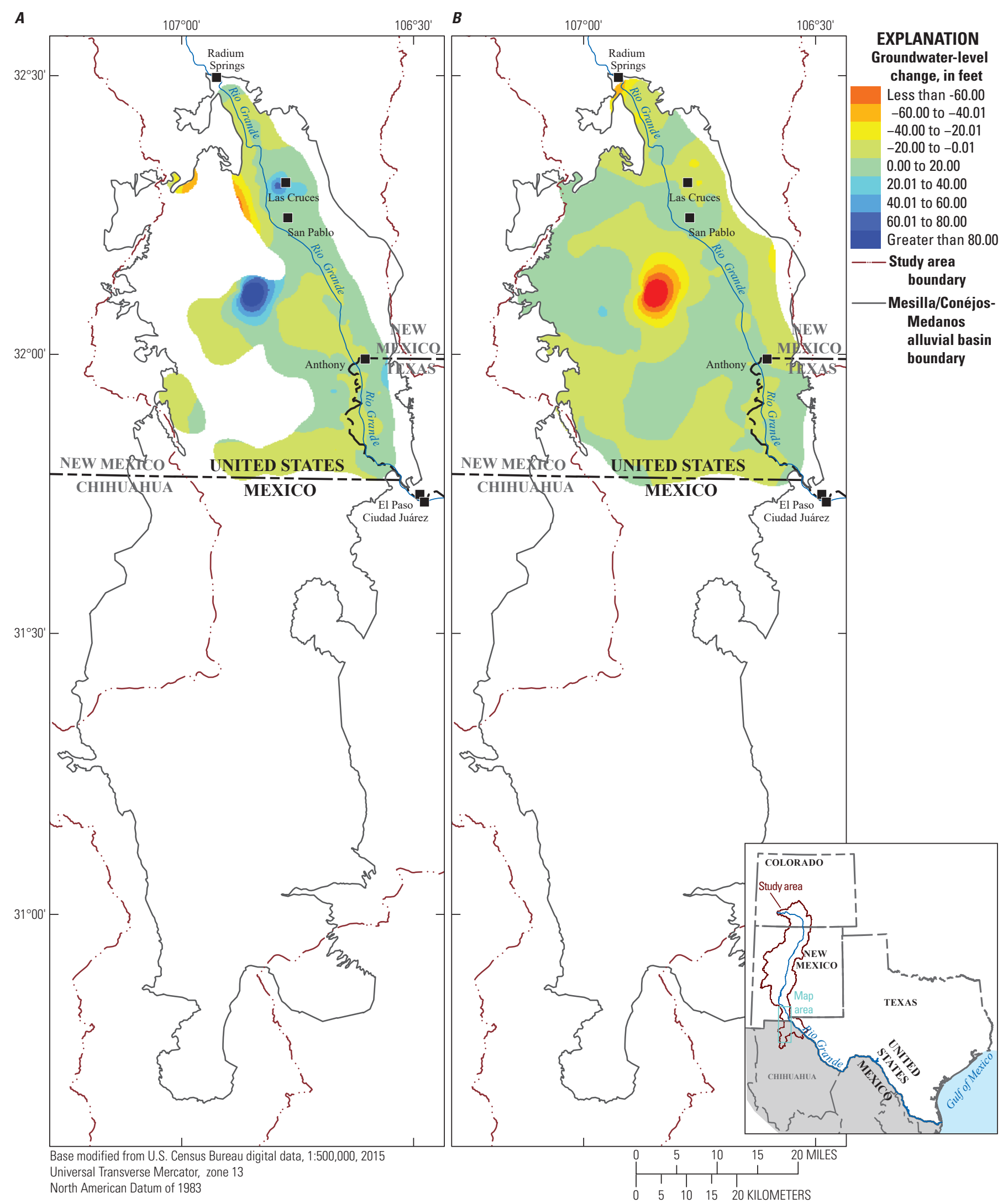

Figure 34. Maps showing median groundwater-level changes for the Mesilla/Conejos-Médanos alluvial basin during A, 1980-85 and B, 1985-90 in New Mexico and Texas in the United States and Chihuahua in Mexico. 


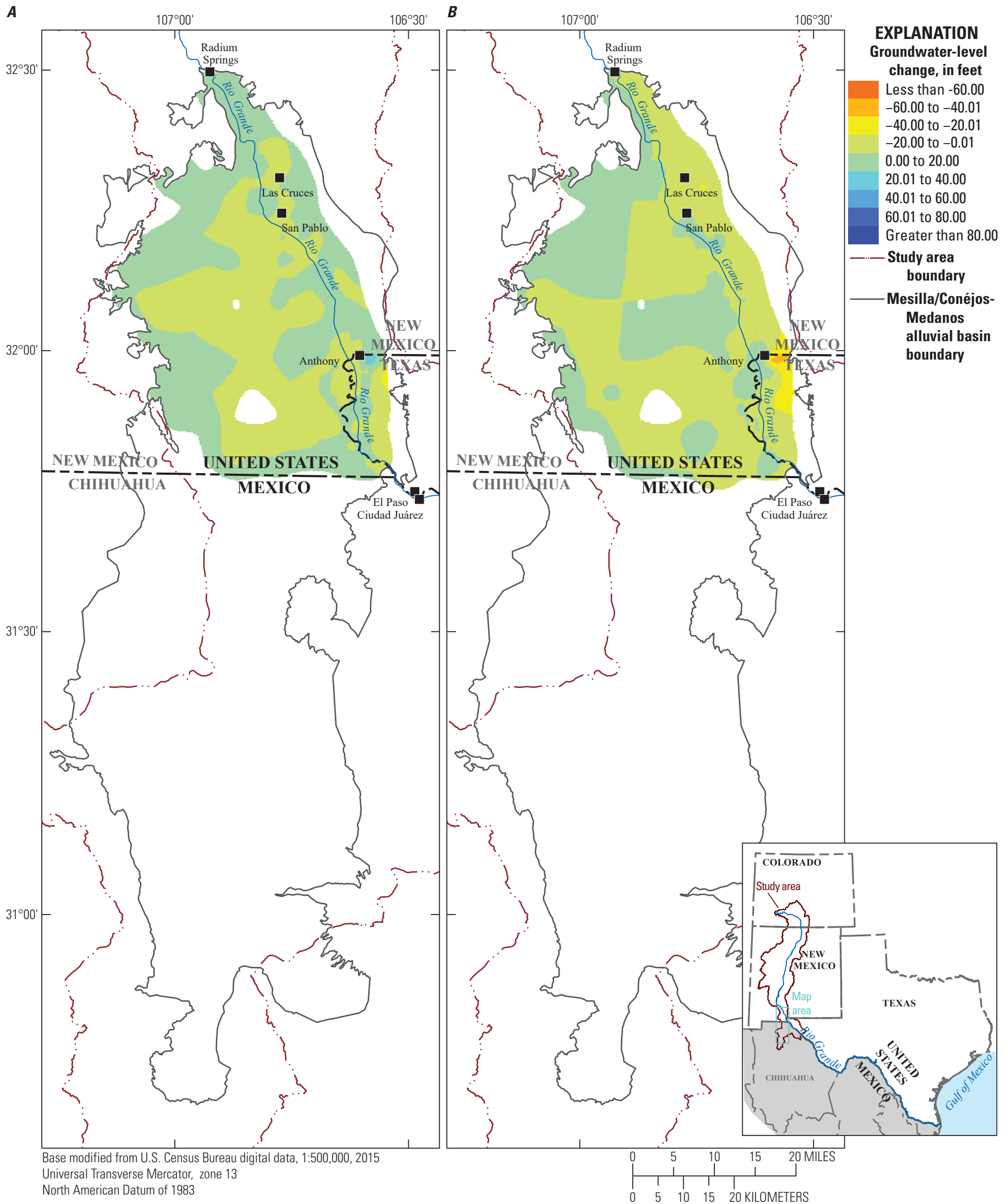

Figure 35. Maps showing median groundwater-level changes for the Mesilla/Conejos-Médanos alluvial basin during $A, 1990-95$ and $B, 1995-2000$ in New Mexico and Texas in the United States and Chihuahua in Mexico. 


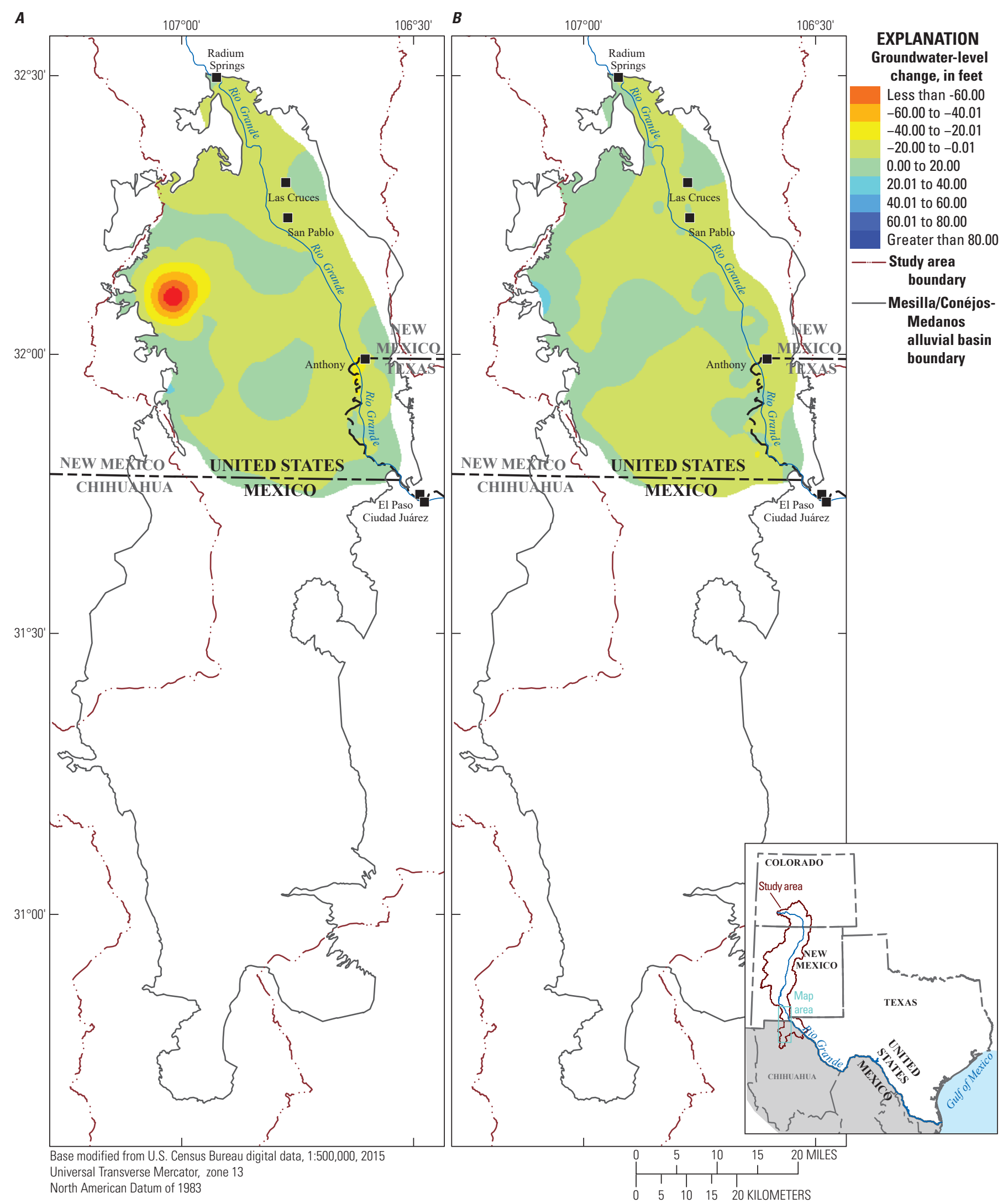

Figure 36. Maps showing median groundwater-level changes for the Mesilla/Conejos-Médanos alluvial basin during A, 2000-05 and B, 2005-10 in New Mexico and Texas in the United States and Chihuahua in Mexico. 


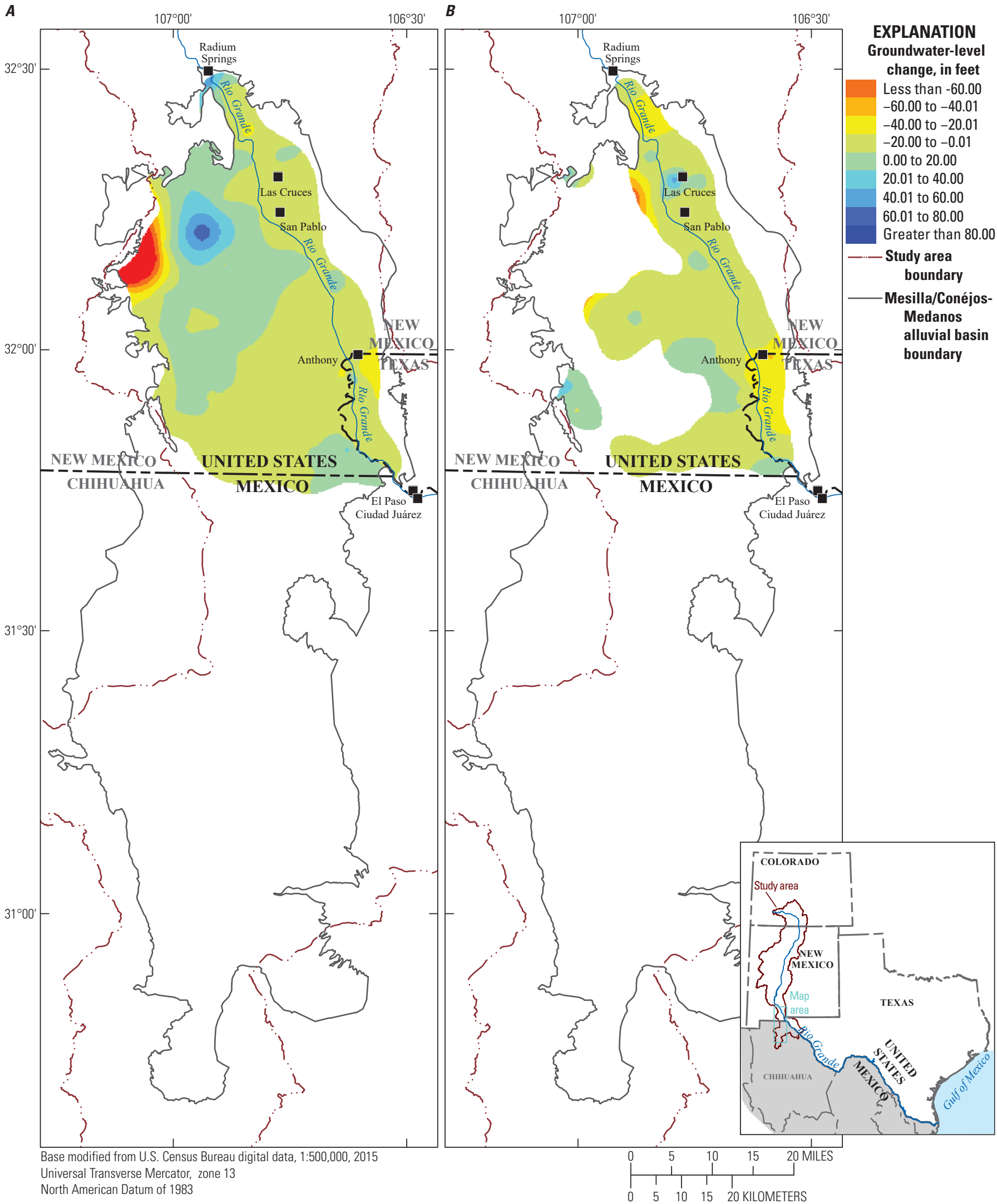

Figure 37. Maps showing median groundwater-level changes for the Mesilla/Conejos-Médanos alluvial basin during $A, 2010-15$ and B, 1980-2015 New Mexico and Texas in the United States and Chihuahua in Mexico. 
The majority of recharge in the Mesilla/ConejosMédanos alluvial basin is from seepage from the Rio Grande and its tributaries, percolation (return flow) from irrigation water, and small amounts of groundwater inflow to the basin and mountain-front recharge from the Franklin Mountains and West Mesa (Sheng, 2013). Nickerson and Myers (1993, p. 20) stated that "the net transfer of water to or from the aquifer system by recharge and discharge mechanisms is related directly to Rio Grande streamflow and the volume of river water used for irrigation." Although the combination of limited and variable recharge along with drought conditions and surface water management practices have complicated the long-term understanding of the groundwater system in the basin, overall, most of the Mesilla/Conejos-Médanos alluvial basin experiences minimal declines in groundwater-level altitudes, with some localized areas experiencing larger declines. Seepage investigation data show that, although there were gaining reaches early in the study period (2009-13) along the Rio Grande during low flow, these reaches became neutral or losing by the end of the study period.

Storage changes for the Mesilla/Conejos-Médanos alluvial basin were estimated for an area of approximately $603 \mathrm{mi}^{2}$ (19 percent of basin; fig. 3). Changes in storage were based on specific yield estimates of 0.10 to 0.20 (Weeden and Maddock, 1999; Hawley and Kennedy, 2004). Smaller specific yield values contribute to more subdued changes, and larger specific yield values contribute to larger changes in storage. The amount of groundwater in storage increased during 1980-85 and slightly in 1990-95, and decreased during 1985-90, 1995-2000, 2000-05, 2005-10, and 2010-15 (fig. 38).

The Rio Grande Transboundary Integrated Hydrologic Model, a numerical groundwater-flow model developed for the Rincon Valley (which spans parts of both the Mesilla/ Conejos-Médanos and Palomas basins), the Mesilla basin, and the northern part of the Mesilla/Conejos-Médanos Basin, was built by Hanson and others (2020) to assess the use and movement of groundwater in this area. Storage declines were seen in relatively recent years starting in 1995 (excluding 2005 and 2007) according to results from this model (fig. 39). Positive storage inflows into the aquifer represent losses of groundwater in storage in figure 39. Although the simulated storage declines from the model generally agree with the cumulative storage declines estimated using groundwater-level altitudes and specific yield estimates, they are generally of higher magnitude. The groundwater-flow model simulates storage in a larger area and at greater depths than that estimated by the storage computation based on groundwater-level changes. The model simulates groundwater from land surface to the bedrock, a total thickness in the thousands of feet. In contrast, the deepest well used in the storage computation for the Mesilla/ Conejos-Médanos alluvial basin, as determined from median 5-year groundwater-level change maps, is $472 \mathrm{ft}$ deep, and the mean well depth was about $110 \mathrm{ft}$.

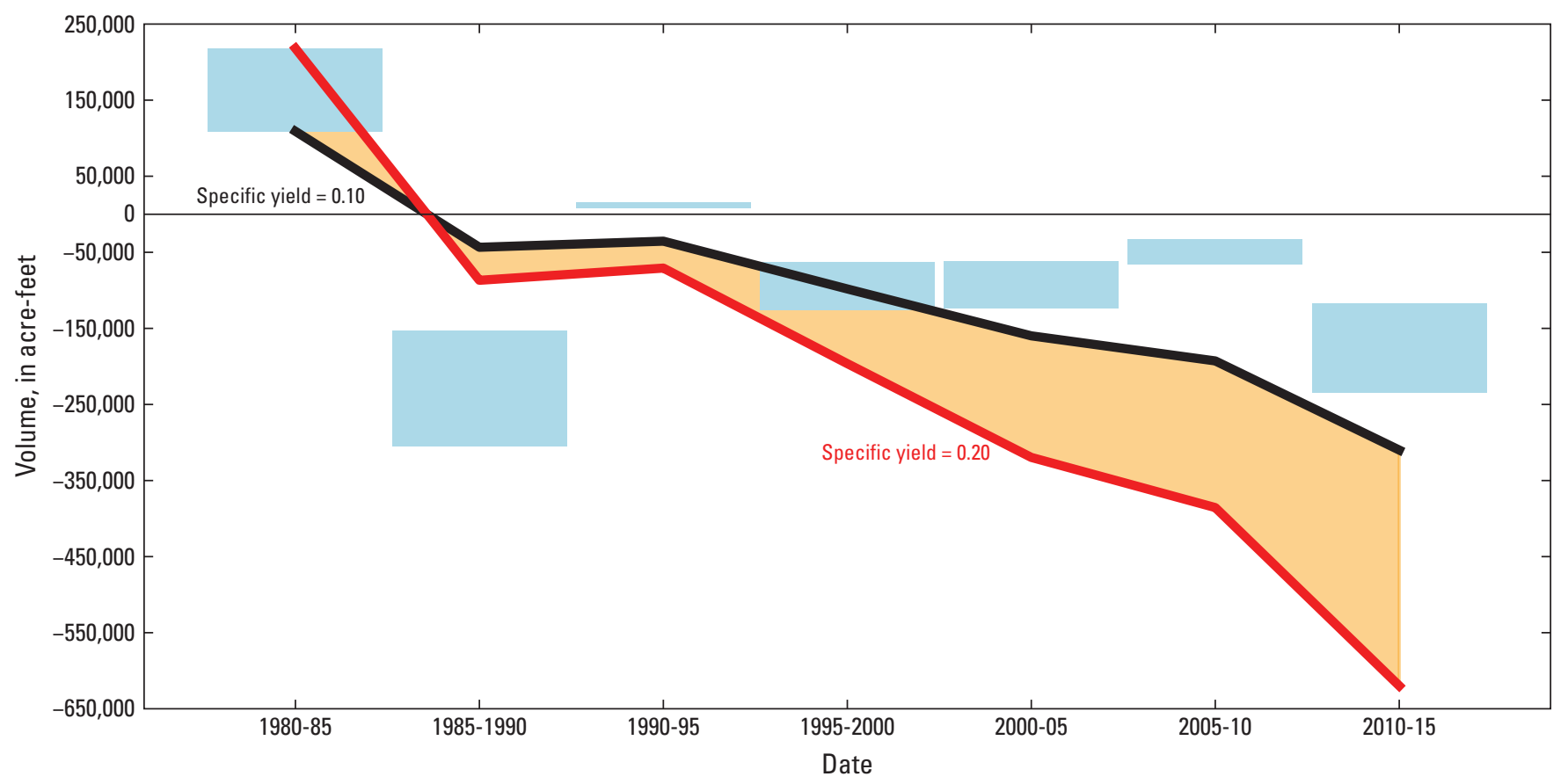

Figure 38. Graph showing ranges of groundwater-storage changes for the Mesilla/Conejos-Médanos alluvial basin for 5-year periods (blue) and cumulative storage change from 1980 to 2015 (red); the black line represents cumulative storage change using specific yield of 0.10 and the red line represents cumulative storage change using specific yield of 0.20 . Blue bars represent the range of storage volume change with one end representing the lower value of specific yield and the other end representing the upper value of specific yield. 


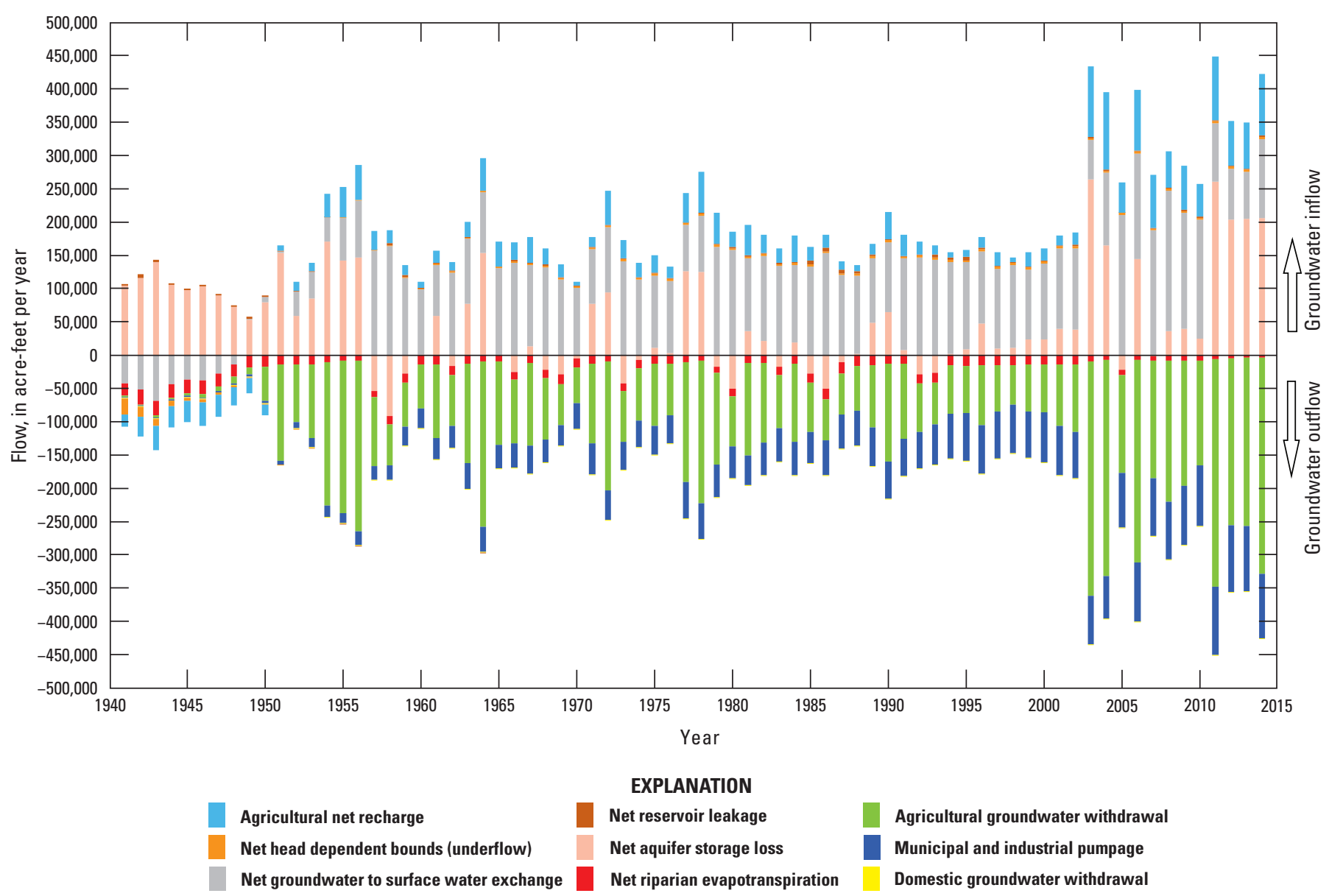

Figure 39. Graph showing simulated groundwater flow values (net flow) for the hydrologic-flow budget from the Rio Grande Transboundary Integrated Hydrologic Model for New Mexico and Texas, United States, and Mexico; modified from Hanson and others (2020, fig. 36A).

\section{Tularosa-Hueco Alluvial Basin}

There were more than 99 wells in the Tularosa-Hueco alluvial basin with groundwater-level measurements for consecutive 5-year periods in individual wells beginning from 1980 to 2005 . There were only 33 wells in the Tularosa-Hueco alluvial basin with groundwater-level measurements available for the consecutive 5-year periods from 2005 to 2010 and only 4 wells with consecutive 5 -year period measurements from 2010 to 2015. Because few groundwater-level data were available for the $2010-15$ period, there were insufficient data to evaluate the 2015 Tularosa-Hueco alluvial basin 5-year period. The largest declines in groundwater-level altitudes in the Tularosa-Hueco alluvial basin were about 39,36 , and $33 \mathrm{ft}$ for the 1980-85, 1985-90, and 1990-95 periods, respectively. The largest rise was about $41 \mathrm{ft}$ for the 1995-2000 period. The largest decline in groundwater-level altitude in the four wells with measurements made in 1980 and 2015 was about $2 \mathrm{ft}$, and the largest rise was approximately $3 \mathrm{ft}$ (table 3 ). For all 5-year periods, median changes in groundwater altitudes declined by about 1 to $7 \mathrm{ft}$ in individual wells measured in consecutive 5-year time periods. Similarly, median groundwater-level altitudes in the Tularosa-Hueco alluvial basin declined by approximately $1.09 \mathrm{ft}$ per 5 -year period in the wells from which groundwater-level measurements were collected during 50 percent or more of the 5-year periods from 1980 to 2015 (table 2). Groundwater-level altitudes declined in 88 percent of the wells in Tularosa-Hueco alluvial basin used in the linear regression slope analysis; most of these wells were clustered around the greater El Paso area.

The small amount of groundwater recharge in the Tularosa-Hueco alluvial basin is in the form of irrigation percolation (return flows), seepage from the Rio Grande and its irrigation canals, mountain-front recharge, forced injection recharge, and reclaimed wastewater returns (Sheng, 2013). In addition to the recharge mechanisms summarized by Sheng (2013), Hutchison and Hibbs (2008, p. 386) reported that "induced infiltration from the Rio Grande alluvium to the Hueco Bolson aquifer amounts to more than 25 percent of current [2021] municipal pumping in El Paso and Ciudad Juárez." Groundwater-level data for the Tularosa-Hueco alluvial basin are primarily available for the area along the Rio Grande from 
just north of El Paso to near Fort Hancock, Tex. (figs. 40-42). Heywood and Yager (2003, p. 5) discussed how "hydrographs of groundwater-level altitudes measured in the United States and Mexico during 1935-96 show that groundwater-level altitudes have declined concurrently with increased groundwater withdrawals." In 1990, El Paso reached its peak annual withdrawal to date [2021] with nearly $80,000 \mathrm{ac}-\mathrm{ft}\left(98.7 \mathrm{Mm}^{3}\right)$ of groundwater withdrawn for municipal supply before reducing its withdrawals from the Tularosa-Hueco alluvial basin to preserve fresh groundwater (Sheng and Devere, 2005; Sheng, 2013). Overall, the groundwater-level altitudes between 1980 and 2010 declined by around 50 to $80 \mathrm{ft}$, where data are available near El Paso, Tex.

Storage changes for the Tularosa-Hueco alluvial basin were estimated for an area of approximately $401 \mathrm{mi}^{2}$ (17 percent of the Hueco Bolson part of the alluvial basin) in the southern part of the basin (fig. 3). Changes in storage were based on specific-yield estimates of 0.05 to 0.30 (Heywood and Yager, 2003; Terracon and others, 2003; Montgomery \& Associates and Hutchison, 2016). Smaller specific yield values contribute to more subdued changes, and larger specific yield values contribute to larger changes in storage. The amount of groundwater in storage increased during 1985-90, but otherwise decreased during all other periods and cumulatively in this part of the basin from 1980 to 2010 (fig. 43).

Two groundwater-flow models for the Tularosa-Hueco alluvial basin area were used to further assess changes in storage for this basin. The model of Heywood and Yager (2003) simulated the Hueco basin from 1903 to 1996 by using a value of 0.178 for specific yield. Montgomery \& Associates and Hutchison (2016) developed a model for the El Paso Water Utility that simulated the Hueco Bolson aquifer from 1977 to 2013 by using a specific yield of 0.177 . Both models indicate declines in storage throughout the modeled periods (fig. 44), which agrees with the storage changes estimated using groundwater levels and specific yield estimates. Similar to the declines in the groundwater level grids (figs. 40-42), the simulated declines were in areas of groundwater withdrawals, such as those near El Paso where surface-water resources needed for agricultural and urban demands are dependent on deliveries from the Elephant Butte and Caballo Reservoirs upstream in New Mexico. The groundwater-flow models simulate a larger area (fig. 3) of the Tularosa-Hueco alluvial basin than the $401 \mathrm{mi}^{2}$ area where storage changes were computed by using the groundwater-level change maps. Furthermore, the groundwater-flow models simulated the groundwater either to a depth of nearly 2,000 ft (Heywood and Yager, 2003) or through the top $200 \mathrm{ft}$ of the middle Santa Fe Group (Montgomery \& Associates and Hutchison, 2016). The depth of the deepest well used for groundwater storage computations for the Tularosa-Hueco alluvial basin using the 5-year median groundwater-level change maps was $506 \mathrm{ft}$, and the mean well depth was about $235 \mathrm{ft}$. 


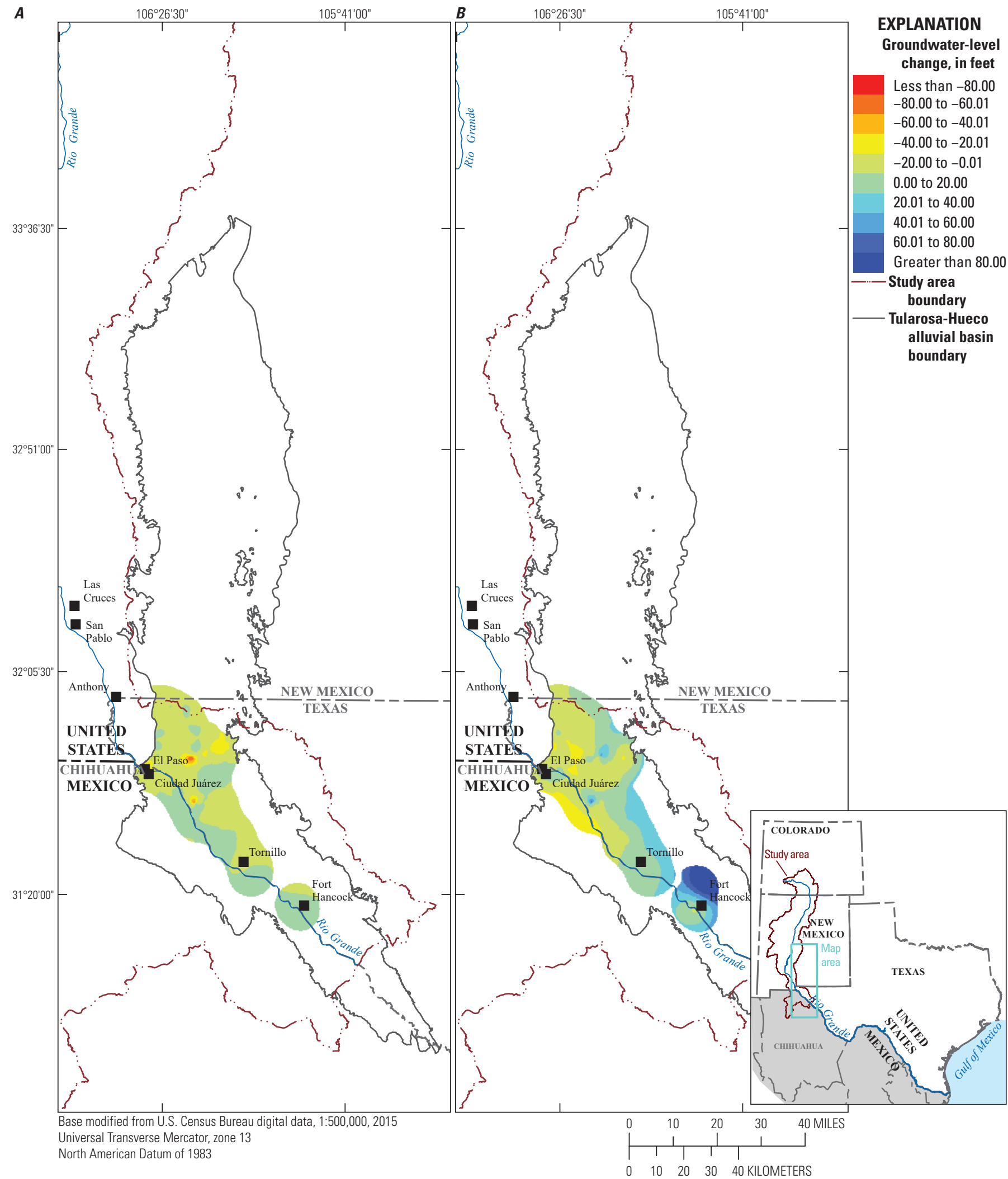

Figure 40. Maps showing median groundwater-level changes for the Tularosa-Hueco alluvial basin during $A, 1980-85$ and $B, 1985-90$ in New Mexico and Texas. 


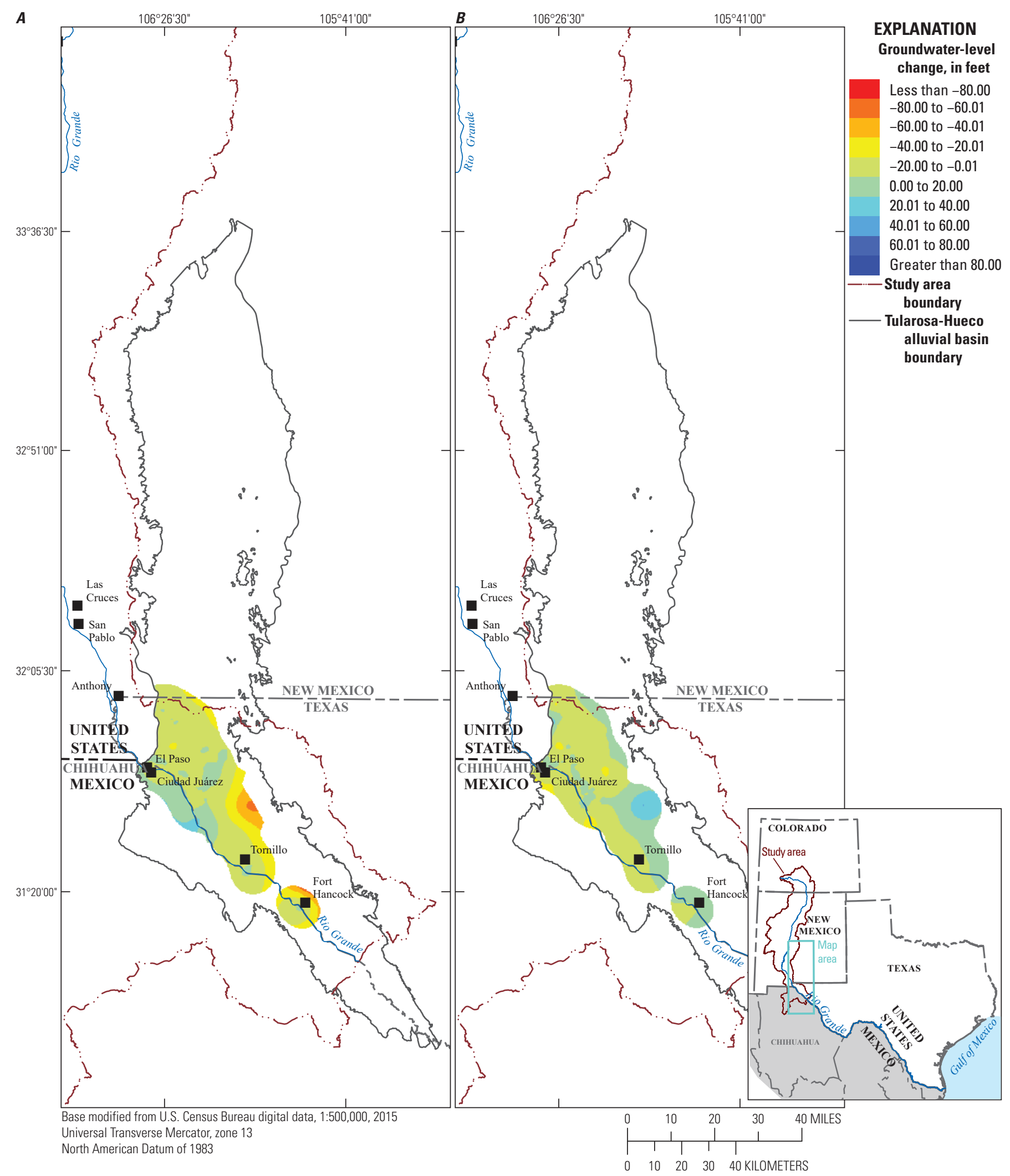

Figure 41. Maps showing median groundwater-level changes for the Tularosa-Hueco alluvial basin during A, 1990-95 and B, 1995-2000 in New Mexico and Texas. 


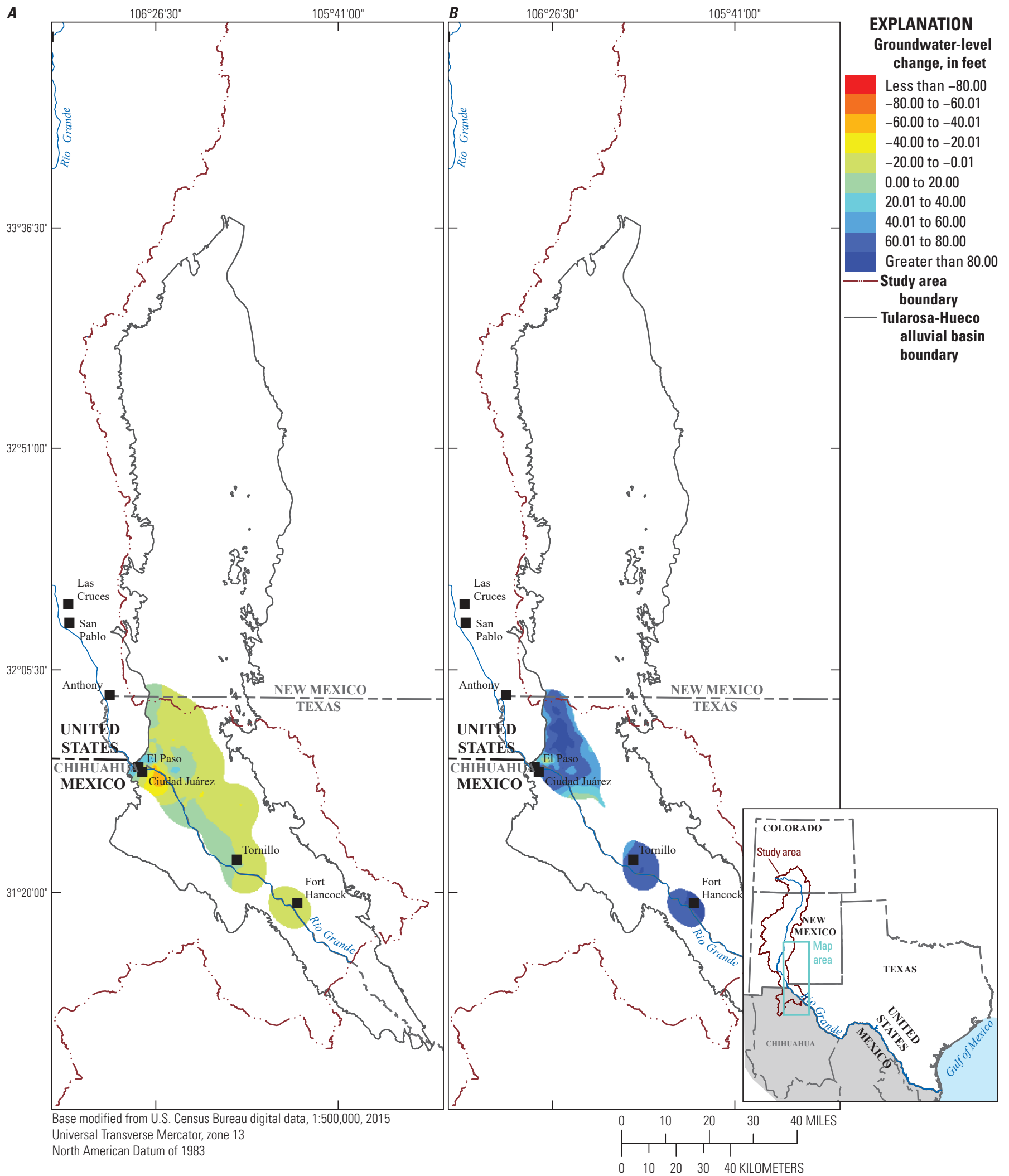

Figure 42. Maps showing median groundwater-level changes for the Tularosa-Hueco alluvial basin during A, 2000-05 and B, 2005-10 in New Mexico and Texas. 


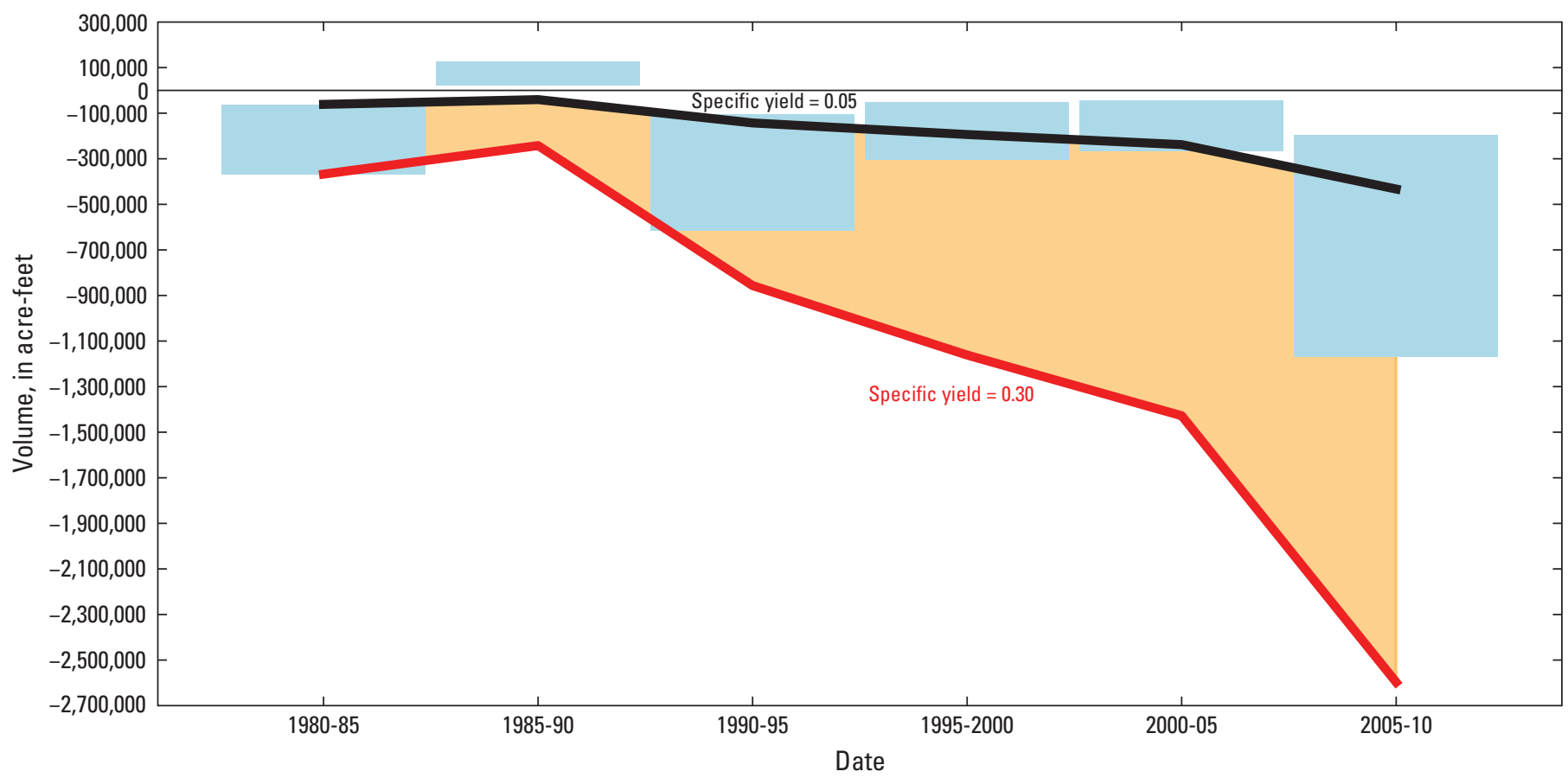

Figure 43. Graph showing ranges of groundwater-storage changes for the Tularosa-Hueco alluvial basin for 5-year periods (blue) and cumulative storage change from 1980 to 2015 (red); the black line represents cumulative storage change using specific yield of 0.05 and the red line represents cumulative storage change using specific yield of 0.30 . Blue bars represent the range of storage volume change with one end representing the lower value of specific yield and the other end representing the upper value of specific yield. 


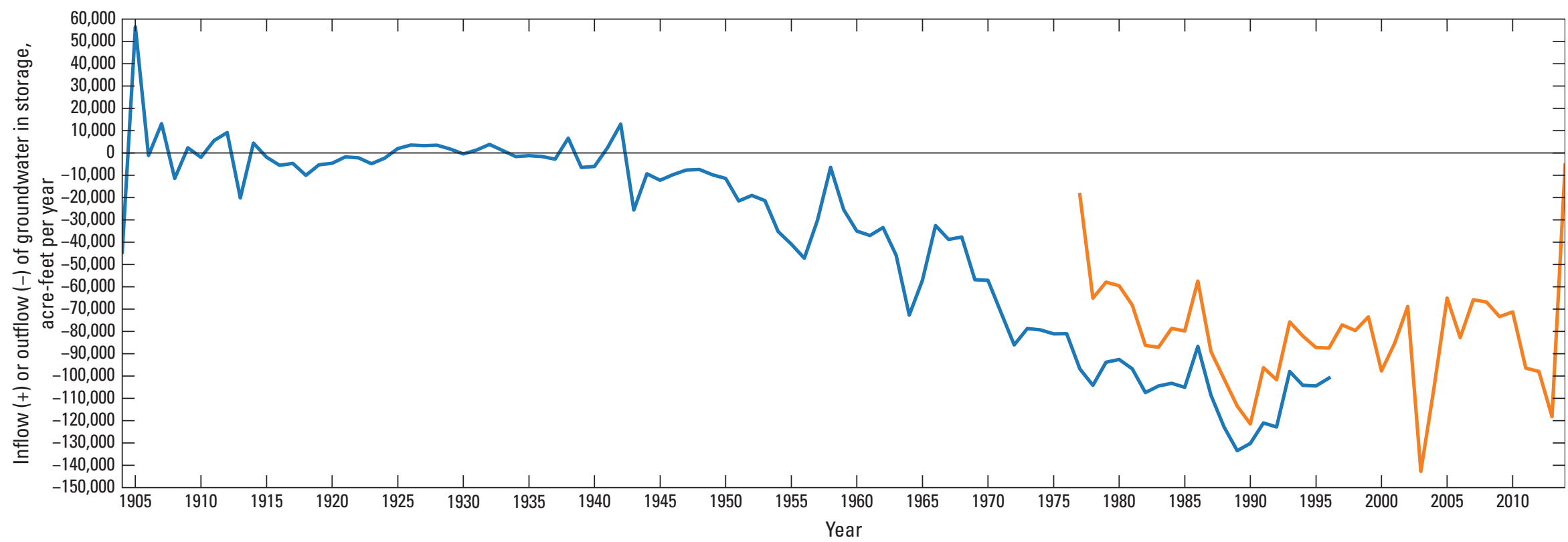

EXPLANATION

\section{Model from Heywood and Yager (2003)}

Model from Montgomery and Associates and Hutchinson (2016)

Figure 44. Graph showing simulated annual inflows to and outflows from groundwater storage in the Hueco Bolson aquifer for the Heywood and Yager (2003) and Montgomery \& Associates and Hutchison (2016) groundwater-flow models. 


\section{Summary}

Increasing demand for the limited water resources of the United States continues to put pressure on resource management agencies to balance the competing needs of ecosystem health with municipal, agricultural, and other uses. To assist resource managers in evaluating these needs, the U.S. Geological Survey conducted a multiyear study to evaluate water resources in the upper Rio Grande Basin in the southwestern United States. The upper Rio Grande Basin extends from south-central Colorado through New Mexico and west Texas, into Chihuahua, Mexico. The upper Rio Grande Basin is composed of a sequence of alluvial basins that formed in the Rio Grande rift approximately 30 million years ago.

This report describes the hydrogeology of the upper Rio Grande Basin and how the groundwater resources in the basin have changed from 1980 to 2015. The hydrogeologic framework includes the horizontal delineation of the alluvial basins within the upper Rio Grande Basin from the headwaters in Colorado to Fort Quitman, Texas, including part of Chihuahua, Mexico. In addition to the extents and descriptions of the alluvial basins, groundwater-level measurements were compiled where available from existing database resources and used to construct groundwater-level altitude and groundwater-level change maps. These groundwater-level altitude maps along with existing groundwater-flow models were used to estimate groundwater-storage change in the alluvial basins.

Kriging algorithms in Oasis montaj were used to determine the most probable value at each $200 \times 200$-meter $(\mathrm{m}$; 656-by-656-foot [ft]) grid node based on a statistical analysis of the entire dataset within the active cells for each grid. Variance maps, automatically developed during the kriging process, were used to evaluate the spatial uncertainty in the groundwater-level altitude maps. These variance maps were used to clip the final groundwater-level altitude grids such that only those data with acceptable uncertainty values were retained.

Median groundwater-level altitudes were plotted, and changes were computed as the linear regression slope of the computed median groundwater-level data for each well to determine the rate of change, provided that there were data for at least 50 percent of the study period. Of the 2,699 wells with groundwater-level data used in this study, 1,055 wells had data for only a single 5-year period, 703 wells had data for 50 percent or more of the 35 years of the study, and only 57 wells had 5-year groundwater-level data for the entire study period. The median slope of groundwater-level altitudes was computed to help evaluate median groundwater-level changes from 1980 to 2015 . Rates of declines greater than $1 \mathrm{ft}$ per 5-year period were measured in 17 percent of the wells; greater than $2 \mathrm{ft}$ per 5-year period, in 3 percent of the wells; and greater than $3 \mathrm{ft}$ per 5 -year period, in 1 percent of the wells. Rises were measured in 14 percent of the 703 wells that contained data for 50 percent or more of the study period. Groundwaterlevel altitudes rose by more than $1 \mathrm{ft}$ per 5-year period in
4 percent of the wells. The median decline in water levels in the upper Rio Grande Basin was $0.13 \mathrm{ft}$ per 5-year period, and declines were measured in 53 percent of the 703 wells that contained data for 50 percent or more of the study period. Rates of water-level decline greater than $1 \mathrm{ft}$ per 5-year period were measured in 17 percent of the wells, greater than $2 \mathrm{ft}$ per 5 -year period, in 3 percent of the wells, and greater than $3 \mathrm{ft}$ per 5-year period, in 1 percent of the wells. Overall, groundwater levels rose in 6 percent of the 703 wells that contained data for 50 percent or more of the study period, and in 4 percent of the wells, groundwater levels rose by $1 \mathrm{ft}$ or more per 5 -year period.

Estimates of changes in groundwater storage were evaluated using two methods. The first method used groundwaterlevel change maps developed for this study and estimates of specific yield from published studies to estimate changes in groundwater storage from 1980 to 2015 . The second method used existing groundwater-flow models for the San Luis, Española, Middle Rio Grande, Mesilla/Conejos-Médanos, and Tularosa-Hueco alluvial basins to quantify changes in groundwater storage.

The San Luis alluvial basin is the second largest alluvial basin in the upper Rio Grande Basin and covers approximately 4,980 square miles $\left(\mathrm{mi}^{2}\right)$. Groundwater-level data compiled for wells with measurements during two consecutive 5-year periods indicated that the largest decline in groundwater-level altitudes in the San Luis alluvial basin was approximately $28 \mathrm{ft}$ between 2000 and 2005, whereas the largest rise in groundwater-level altitude was approximately $32 \mathrm{ft}$ between 1990 and 1995. Median groundwater-level altitudes were essentially stable in the San Luis alluvial basin during the study period, increasing at a rate of $0.01 \mathrm{ft}$ per 5 -year period for wells from which groundwater-level measurements were collected during 50 percent or more of the 5-year periods from 1980 to 2015. Groundwater storage increased from 1980 to 1990 , but overall, largely decreased from 1980 to 2015. Groundwater depletion in the unconfined aquifer in the San Luis Valley in southern Colorado recovered between late 2013 and early 2018 following conservation efforts. However, severe drought that persisted in the upper Rio Grande Basin well into 2020, particularly in southern Colorado, offset some of the recovery attributed to conservation efforts.

The Española alluvial basin is approximately 2,350 $\mathrm{mi}^{2}$ and is connected to the San Luis alluvial basin to the north at the Embudo Constriction and to the Middle Rio Grande alluvial basin to the south at the La Bajada Constriction. The Española alluvial basin has the second highest mountain peaks of the 13 alluvial basins in this study, with topography ranging from about 5,330 to $11,570 \mathrm{ft}$ above the North American Vertical Datum of 1988 (NAVD 88) and the third highest median land-surface altitude at about $6,870 \mathrm{ft}$ above NAVD 88. The largest 5-year declines in the Española alluvial basin in groundwater-level altitudes were approximately 183 , 199, 295, and $163 \mathrm{ft}$ during 1985-90, 1990-95, 1995-2000, and 2000-05, respectively. Large rises in groundwaterlevel altitudes of approximately 275, 277, and $225 \mathrm{ft}$ were 
observed during 2000-05, 2005-10, and 2010-15, respectively. Median groundwater-level altitudes in the Española alluvial basin declined slightly at a rate of $-0.17 \mathrm{ft}$ per 5 -year period in wells from which groundwater-level measurements were collected during 50 percent or more of 5-year periods from 1980 to 2015 . Approximately 71 percent of these wells showed declines (with the largest rate of change in Santa Fe's Buckman well field), and 25 percent of the wells with declines declined at rates in excess of 1 - $\mathrm{ft}$ per 5 -year period. Groundwater storage increased during 2000-05 and 2010-15 and decreased in the other 5-year periods, for an overall similar amount of groundwater storage in 2015 when compared with 1985. A groundwater-flow model for the Tesuque aquifer in the Española Basin that simulated groundwater conditions from 1947 to 1982 indicated declines in groundwater in storage during that period.

The Middle Rio Grande alluvial basin extends from the Cochiti Dam to San Acacia, N. Mex., and covers approximately 3,020 $\mathrm{mi}^{2}$. It is one of the larger basins in the upper Rio Grande Basin and one of the deepest, with basin-fill deposits in the Santa Fe Group ranging from about 1,400 ft thick at the margins to about $14,000 \mathrm{ft}$ at the deepest areas. Within the Middle Rio Grande alluvial basin, at least 42 wells have measurements in two consecutive 5-year periods for all date ranges. Median groundwater-level changes measured at individual wells declined during each period from 1980 to 2005. Median groundwater-level altitudes in the Middle Rio Grande alluvial basin declined slightly $(0.01 \mathrm{ft}$ per 5 -year period) in wells with groundwater-level measurements for at least 50 percent of the 1980-2015 periods. Groundwater storage decreased for most of the study period except during 1980-85, 2000-05, and 2010-15. Although some monitoring wells near the old municipal production wells in the Albuquerque basin show recovery in groundwater storage since the replacement of large volumes of groundwater withdrawals by water from the San Juan-Chama Project in 2010, other areas in the Middle Rio Grande alluvial basin continue to show declines.

The San Agustin alluvial basin is approximately $1,010 \mathrm{mi}^{2}$ and has the second highest median land-surface altitude at about 7,000 ft above NAVD 88, with altitudes ranging from about 6,030 to $8,000 \mathrm{ft}$ above NAVD 88 . The largest decline in groundwater-level altitude at an individual well of approximately $13 \mathrm{ft}$ was observed during 1990-95, and the largest rise in groundwater-level altitude was approximately $14 \mathrm{ft}$ during 1995-2000. During the study period, no individual wells with measurement in both 1980 and 2015 showed rises, and largest decline in groundwater-level altitudes was about $34 \mathrm{ft}$. Evaluating the 23 wells from which groundwaterlevel measurements were collected during 50 percent or more of the 5-year periods, the median groundwater-level altitudes in the San Agustin alluvial basin were relatively stable, but there were insufficient data to estimate groundwaterstorage changes.
The Socorro, La Jencia, San Marcial, Alamosa Creek, and Engle alluvial basins did not have enough data to complete a detailed assessment for the 5-year periods and provide a meaningful analysis. The Socorro alluvial basin is the third smallest alluvial basin in the central part of the upper Rio Grande Basin, covering a little more than $390 \mathrm{mi}^{2}$, and has the smallest amount of topographic relief of the alluvial basins. The La Jencia alluvial basin is the smallest alluvial basin in the study area, covering a little more than $200 \mathrm{mi}^{2}$ in the central part of the upper Rio Grande alluvial basin is the second smallest alluvial basin in the upper Rio Grande basin, covering a little less than $300 \mathrm{mi}^{2}$. The San Marcial alluvial basin covers approximately $470 \mathrm{mi}^{2}$, but there is minimal development in the basin and relatively little detailed hydrogeologic information. The Engle alluvial basin covers a little more than $410 \mathrm{mi}^{2}$ and contains the Elephant Butte Reservoir.

Covering approximately $890 \mathrm{mi}^{2}$ in the central part of the upper Rio Grande Basin, the Palomas alluvial basin is the eighth largest alluvial basin in the upper Rio Grande Basin. There are at least 29 wells in each 5-year period with measurements for consecutive 5 -year periods. The maximum groundwater-level altitude decline in individual wells was about $87 \mathrm{ft}$ during 2010-15, and the largest rise was about $64 \mathrm{ft}$ during 1980-85. The median 5-year change in groundwater-level altitudes for wells with measurements in consecutive 5-year periods ranged from a decrease of about $2 \mathrm{ft}$ to a rise of about $1.4 \mathrm{ft}$, with declines in four of the seven 5 -year periods. Median groundwater-level altitudes in the Palomas alluvial basin are relatively stable for wells from which groundwater-level measurements were collected during 50 percent or more of the 5-year periods from 1980 to 2015. Groundwater-level declines were observed in 49 percent of the wells, and no change (less than $0.1 \mathrm{ft}$ or rise or decline) was observed in 38 percent of the wells. Groundwater storage increased during 1980-90, 1995-2000 and 2005-10, but similar to median groundwater levels, cumulative groundwater storage remained comparable in 2015 relative to 1985 .

Located in an extension-dominated terrace, the Jornada del Muerto alluvial basin is unique among the alluvial basins of the upper Rio Grande Basin in that it exhibits minimal faulting and extension. The Jornada del Muerto alluvial basin extends more than 2,250 $\mathrm{mi}^{2}$ from near Socorro, N. Mex., south to near Las Cruces, N. Mex. Groundwater-level declines at individual wells measured in consecutive 5-year periods were about 39 and $40 \mathrm{ft}$ during 1990-95 and 2005-10, respectively. The largest rises in groundwater-level altitudes in these wells were about 84 and $71 \mathrm{ft}$ during 1985-90 and 2005-10, respectively. Median groundwater-level altitudes in the Jornada del Muerto alluvial basin were relatively stable (less than $0.1 \mathrm{ft}$ of rise or decline) for wells from which groundwater-level measurements were collected during 50 percent or more of the 5-year periods from 1980 to 2015. Groundwater-level declines were observed in 43 percent of the wells, and rises were observed in 29 percent of the 21 wells. 
There were not enough groundwater-level measurements either spatially or temporally to estimate changes in storage in this alluvial basin.

The Mesilla/Conejos-Médanos alluvial basin is the third largest alluvial basin the study area, covering nearly $3,150 \mathrm{mi}^{2}$, and although one of the largest basins in the upper Rio Grande Basin, it has the fourth smallest topographic relief. The Mesilla/Conejos-Médanos alluvial basin has the most wells with measurements in consecutive 5-year periods. The largest decline in groundwater-level altitudes in a single well was about $28 \mathrm{ft}$ during $1980-85$, and the largest rise was about $188 \mathrm{ft}$ during 1980-85. During the entire study period, 40 wells had measurements in both 1980 and 2015 , with a maximum decline of about $17 \mathrm{ft}$ and maximum rise of about $50 \mathrm{ft}$. The median 5-year change in single wells showed declines after 1995. Groundwater-level altitudes in the Mesilla/Conejos-Médanos alluvial basin declined at a median rate of $0.10 \mathrm{ft}$ per 5 -year period for the 169 wells from which groundwater-level measurements were collected during 50 percent or more of the 5-year periods from 1980 to 2015. Groundwater-level altitudes declined in 51 percent of these 169 wells, and 43 percent had relatively no change during the study period. Estimated groundwater storage increased during 1980-85 and then mostly decreased from 1985 to 2015 . Similarly, a numerical groundwater-flow model developed for the parts of the Palomas and Mesilla/Conejos-Médanos alluvial basins showed groundwater storage declines starting in 1995 (excluding 2005 and 2007).

Although the Tularosa-Hueco alluvial basin is the largest alluvial basin of the 13 alluvial basins in this study at a little more than $5,390 \mathrm{mi}^{2}$, only the Hueco part of the alluvial basin is in the upper Rio Grande basin, and its area is about 2,390 $\mathrm{mi}^{2}$. At about 4,030 ft above NAVD 88, the TularosaHueco alluvial basin has the second lowest median landsurface altitude of the alluvial basins. The largest decline in groundwater-level altitudes was about $39 \mathrm{ft}$ during 1980-85, and the largest rise was about $41 \mathrm{ft}$ during 1995-2000. Median groundwater-level altitudes declined by approximately $1.09 \mathrm{ft}$ per 5-year period in the Tularosa-Hueco alluvial basin for wells from which groundwater-level measurements were collected during 50 percent or more of the 5 -year periods from 1980 to 2015. The wells that were used in the linear regression slope analysis were generally clustered around the greater El Paso area; 88 percent of these wells showed groundwaterlevel declines. Groundwater storage increased during 1985-1990, but otherwise decreased for an overall decrease in this part of the basin from 1980 to 2010. Two groundwaterflow models for the Tularosa-Hueco alluvial basin were used to assess changes in groundwater storage for this basin. Both models indicate decreases in groundwater storage during their modeled periods.

\section{References Cited}

Alley, W.M., Reilly, T.E., and Franke, O.L., 1999, Sustainability of ground-water resources: U.S. Geological Survey Circular 1186, 79 p., accessed December 17, 2020, at https://doi.org/10.3133/cir1186.

Anderholm, S.K., 1983, Hydrogeology of the Socorro and La Jencia Basins, Socorro County, New Mexico, in Chapin, C.E., and Callender, J.F., eds., New Mexico Geological Society, Socorro region II, 34th annual fall field conference guidebook: Socorro, New Mexico Geological Society, p. 303-310, accessed June 28, 2020, at https://nmg s.nmt.edu/publications/guidebooks/downloads/34/34 p0303_p0310.pdf.

Anderholm, S.K., 1987, Hydrogeology of the Socorro and La Jencia basins, Socorro County, New Mexico: U.S. Geological Survey Water-Resources Investigations Report 84-4342, 62 p., 4 pls., accessed June 28, 2020, at https://doi.org/10.3133/wri844342.

Asquith, W.H., Seanor, R.C., McGuire, V.L., and Kress, W.H., 2019, Source code in R to quality assure, plot, summarize, interpolate, and extend groundwater level information, visGWDB - Groundwater level informatics with demonstration for the Mississippi River Valley alluvial aquifer: U.S. Geological Survey software, accessed June 28, 2020, at https://doi.org/10.5066/P9W004O6.

Barroll, P., 2001, Documentation of the administrative groundwater model for the Middle Rio Grande Basin: New Mexico Office of the State Engineer Hydrology Bureau Report 99-3, 52 p., accessed June 28, 2020, at https://www.ose.st ate.nm.us/Library/HydrologyReports/TDH-99-3.pdf.

Bartolino, J.R., and Cole, J.C., 2002, Ground-water resources of the Middle Rio Grande Basin, New Mexico: U.S. Geological Survey Circular 1222, 132 p., accessed June 28, 2020, at https://doi.org/10.3133/cir1222.

Basabilvazo, G.T., 1997, Groundwater resources of Catron County, New Mexico: U.S. Geological Survey WaterResources Investigation 96-4258, 141 p., accessed February 27, 2019, at https://doi.org/10.3133/wri964258.

Bexfield, L.M., 2010, Section 11-Conceptual understanding and groundwater quality of the basin-fill aquifer in the Middle Rio Grande Basin, New Mexico, in Thiros, S.A., Bexfield, L.M., Anning, D.W., and Huntington, J.M., eds., Conceptual understanding and groundwater quality of selected basin-fill aquifers in the southwestern United States: U.S. Geological Survey Professional Paper 1781, p. 189-218, accessed June 1, 2018, at https://doi.org/ $10.3133 / \mathrm{pp} 1781$. 
Bexfield, L.M., and Anderholm, S.K., 2000, Predevelopment water-level map of the Santa Fe Group aquifer system in the Middle Rio Grande Basin between Cochiti Lake and San Acacia, New Mexico: U.S. Geological Survey WaterResources Investigations Report 00-4249, 1 sheet, accessed June 28, 2020, at https://doi.org/10.3133/wri004249.

Bexfield, L.M., and Anderholm, S.K., 2011, Section 10Conceptual understanding and groundwater quality of the basin-fill aquifer in the San Luis Valley, Colorado and New Mexico, in Thiros, S.A., Bexfield, L.M., Anning, D.W., and Huntington, J.M., eds., 2010, Conceptual understanding and groundwater quality of selected basin-fill aquifers in the southwestern United States: U.S. Geological Survey Professional Paper 1781, p. 165-188, accessed June 28, 2020, at https://doi.org/10.3133/pp1781.

Bexfield, L.M., Heywood, C.E., Kauffman, L.J., Rattray, G.W., and Vogler, E.T., 2011, Hydrogeologic setting and groundwater-flow simulation of the Middle Rio Grande Basin regional study area, New Mexico, sec. 2 of Eberts, S.M., ed., Hydrologic settings and groundwater flow simulations for regional investigations of the transport of anthropogenic and natural contaminants to public-supply wells - Investigations begun in 2004: U.S. Geological Survey Professional Paper 1737-B, p. 2-1-2-61, accessed June 28, 2020, at https://doi.org/10.3133/pp1737B.

Bowlin, N., 2019, Colorado farmers fight to save their water and their community's future: High Country News, September 16, accessed July 26, 2020, at https://www.hcn.org/issues/51.16/water-colorado-farmersfight-to-save-their-water-and-their-communitys-future.

Bravo, E., 2018, An aquifer from the ice age becomes a battleground in New Mexico: EcoWatch, November 1, accessed July 26, 2020, at https://www.ecowatch.com/ aquifer-ice-age-new-mexico-2616863799.html?rebelltitem= 1\#rebelltitem1.

Brister, B.S., and Gries, R.R., 1994, Tertiary stratigraphy and tectonic development of the Alamosa basin (northern San Luis Basin), Rio Grande rift, south-central Colorado, in Keller, G.R., and Cather, S.M., eds., Basins of the Rio Grande rift-Structure, stratigraphy, and tectonic setting: Geological Society of America Special Paper 291, p. 39-58, accessed June 28, 2020, at https://doi.org/10.1130/ SPE291-p39.

Bureau of Reclamation, 2016, Rio Grande Basin, chap. 7 of SECURE Water Act section 9503(c) - Reclamation climate change and water 2016: Bureau of Reclamation report to Congress, p. 7-1-7-19, accessed June 28, 2020, at https://www.usbr.gov/climate/secure/docs/2016secure/ 2016SECUREReport.pdf.
Chapin, C.E., 1971, The Rio Grande rift, Part 1Modifications and additions, in James, H.L., ed., New Mexico Geological Society, San Luis Basin (Colorado), 22d annual fall field conference guidebook: Socorro, New Mexico Geological Society, p. 191-201, accessed December 10, 2020, at https:/nmgs.nmt.edu/publications/ guidebooks/downloads/22/22_p0191_p0201.pdf.

Chavez, C.Y., 2020, Water matters-Santa Feans put priority on conserving water: Santa Fe New Mexican, July 5, accessed September 29, 2020, at https://www.santafenewme xican.com/life/home/water-matters-santa-feans-put-priorityon-conserving-water/article_1ad7c9ca-b730-11ea-8be9dfbac84b91e1.html.

City of Santa Fe, 2020a, Buckman wells water level monitoring program: City of Santa Fe web page, accessed April 15, 2020, at https://www.santafenm.gov/buckman_wells_ water_level_monitoring_program.

City of Santa Fe, 2020b, Buckman well water-level monitoring program-Response to condition of approval no. 5, permit no. RG-20516-S-10 thru RG-20516-S-13, City of Santa Fe: City of Santa Fe, 6 p., accessed April 15, 2020, at https://www.santafenm.gov/document_center/ document $/ 805$.

Connell, S.D., Smith, G.A., Geissman, J.W., and McIntosh, W.C., 2013, Climatic controls on nonmarine depositional sequences in the Albuquerque basin, Rio Grande rift, northcentral New Mexico, in Hudson, M.R., and Grauch, V.J.S., eds., New perspectives on Rio Grande rift basins-From tectonics to groundwater: Geological Society of America Special Paper 494, p. 383-425, accessed October 10, 2019 , at https://doi.org/10.1130/2013.2494(15).

Davis Engineering Service, Inc., and Principia Mathematica, Inc., 2017, San Luis valley well and water-level database: Principia Mathematica, Inc. database, accessed April 1, 2017, at https://www.prinmath.com/rgwed/.

Drenth, B.J., Grauch, V.J.S., and Rodriguez, B.D., 2013, Geophysical constraints on Rio Grande rift structure in the central San Luis Basin, Colorado and New Mexico, in Hudson, M.R., and Grauch, V.J.S., eds., New perspectives on Rio Grande rift basins-From tectonics to groundwater: Geological Society of America Special Paper 494, p. 75-99, accessed October 10, 2019, at https://doi.org/10.1130/ 2013.2494(04).

Driscoll, J.M., and Sherson, L.R., 2016, Variability of surfacewater quantity and quality and shallow groundwater-level altitudes and quality within the Rio Grande project area, New Mexico and Texas, 2009-13: U.S. Geological Survey Scientific Investigations Report 2016-5006, 33 p., accessed December 23, 2020, at https://doi.org/10.3133/sir20165006. 
Evenson, E.J., Jones, S.A., Barber, N.L., Barlow, P.M., Blodgett, D.L., Bruce, B.W., Douglas-Mankin, K., Farmer, W.H., Fischer, J.M., Hughes, W.B., Kennen, J.G., Kiang, J.E., Maupin, M.A., Reeves, H.W., Senay, G.B., Stanton, J.S., Wagner, C.R., and Wilson, J.T., 2018, Continuing progress toward a national assessment of water availability and use: U.S. Geological Survey Circular 1440, 64 p., accessed December 23, 2020, at https://doi.org/10.3133/cir1440.

Falk, S.E., Bexfield, L.M., and Anderholm, S.K., 2011, Estimated 2008 groundwater potentiometric surface and predevelopment to 2008 water-level change in the Santa Fe Group aquifer system in the Albuquerque area, central New Mexico: U.S. Geological Survey Scientific Investigations Map 3162, 1 sheet, accessed June 28, 2020, at https://doi.org/10.3133/sim3162.

Frenzel, P.F., 1995, Geohydrology and simulation of groundwater flow near Los Alamos, north-central New Mexico: U.S. Geological Survey Water-Resources Investigations Report 95-4091, 92 p., accessed December 23, 2020, at https://doi.org/10.3133/wri954091.

Garrabrant, L.A., 1993, Water resources of Taos County, New Mexico: U.S. Geological Survey Water-Resources Investigations Report 93-4107, 86 p., accessed June 28, 2020, at https://doi.org/10.3133/wri934107.

Glaser, L.S., 2011, San Juan-Chama project: Bureau of Reclamation, 28 p., accessed February 22, 2021, at https://www.usbr.gov/projects/pdf.php?id=186.

Grauch, V.J.S., and Connell, S.D., 2013, New perspectives on the geometry of the Albuquerque basin, Rio Grande rift, New Mexico-Insights from geophysical models of rift-fill thickness, in Hudson, M.R., and Grauch, V.J.S., eds., New perspectives on Rio Grande rift basins-From tectonics to groundwater: Geological Society of America Special Paper 494, p. 427-462, accessed October 10, 2019, at https://doi.org/10.1130/2013.2494(16).

Grauch, V.J.S., Bauer, P.W., Drenth, B.J., and Kelson, K.I., 2017, A shifting rift - Geophysical insights into the evolution of Rio Grande rift margins and the Embudo transfer zone near Taos, New Mexico: Geosphere, v. 13, no. 3, p. 870-910, accessed December 23, 2020, at https://doi.org/ 10.1130/GES01425.1.

Grauch, V.J.S., Phillips, J.D., Koning, D.J., Johnson, P.S., and Bankey, V., 2009, Geophysical interpretations of the southern Española Basin, New Mexico, that contribute to understanding its hydrogeologic framework: U.S. Geological Survey Professional Paper 1761, 88 p., accessed June 28, 2020, at https://doi.org/10.3133/pp1761.
Gutzler, D.S., 2003, Drought in New Mexico-History, causes, and future prospects, in Johnson, P.S., Land, L.A., Price, L.G., and Titus, F., eds., Water resources of the lower Pecos region, New Mexico-Science, policy, and a look to the future: New Mexico Bureau of Geology and Mineral Resources decision-makers field conference, p. 101-105, accessed November 4, 2020, at https://geoinfo. nmt.edu/ publications/guides/decisionmakers/2003/DecisonMake rs2003.pdf.

Hanson, R.T., Ritchie, A.B., Boyce, S.E., Galanter, A.E., Ferguson, I.A., Flint, L.E., Flint, A.L., and Henson, W.R., 2020, Rio Grande transboundary integrated hydrologic model and water-availability analysis, New Mexico and Texas, United States, and northern Chihuahua, Mexico: U.S. Geological Survey Scientific Investigations Report 2019-5120, 186 p., accessed June 28, 2020, at https://doi.org/10.3133/sir20195120.

Harmon, E., Heath, J., Thompson, K., Sullivan, M., Schreüder, W., Madebo, A., and Halstead, M., 2016, Phase 6 groundwater model enhancement summary-Final: Colorado Division of Water Resources, 10 p., accessed June 29, 2020, at https://dnrweblink.state.co.us/cwcbsearch/ ElectronicFile.aspx?docid=199984\&dbid=0.

Hawley, J.W., and Kennedy, J.F., 2004, Creation of a digital hydrogeologic framework model of the Mesilla basin and southern Jornada del Muerto Basin: New Mexico Water Resources Research Institute Technical Completion Report 332, 105 p., 7 pls., apps., accessed June 28, 2020, at https://nmwrri.nmsu.edu/wp-content/uploads/2015/ technical-reports/tr332.pdf.

Hawley, J.W., Kennedy, J.F., and Creel, B.J., 2001, The Mesilla basin aquifer system of New Mexico, west Texas and Chihuahua-An overview of its hydrogeologic framework and related aspects of groundwater flow and chemistry, chap. 7 of Mace, R.E., Mullican, W.F., III, and Angle, E.S., eds., Aquifers of west Texas: Texas Water Development Board Report 356, p. 76-99, accessed September 20, 2018, at http://www.twdb. texas.gov/publications/reports/numbered_reports/doc/r356/ chapter7.pdf.

Hearne, G.A., 1985, Mathematical model of the Tesuque aquifer system near Pojoaque, New Mexico: U.S. Geological Survey Water-Supply Paper 2205, 75 p., accessed June 28, 2020, at https://doi.org/10.3133/wsp2205.

Heywood, C.E., 2013, Simulations of groundwater flow, transport, and age in Albuquerque, New Mexico, for a study of transport of anthropogenic and natural contaminants (TANC) to public-supply wells: U.S. Geological Survey Scientific Investigations Report 2012-5242, 51 p., accessed June 28, 2020, at https://doi.org/10.3133/sir20125242. 
Heywood, C.E., and Yager, R.M., 2003, Simulated groundwater flow in the Hueco Bolson, an alluvial-basin aquifer system near El Paso, Texas: U.S. Geological Survey WaterResources Investigations Report 02-4108, 73 p., accessed June 28, 2020, at https://doi.org/10.3133/wri024108.

Hoffer, J.M., 1976, Geology of Potrillo basalt field, southcentral New Mexico: New Mexico Bureau of Mines and Mineral Resources Circular 149, 30 p., accessed June 28, 2020, at https://geoinfo.nmt.edu/publications/monographs/ circulars/downloads/149/Circular-149.pdf.

Houston, N.A., Pedraza, D.E., Thomas, J.V., Foster, L.K., and Welborn, T.L., 2020, Hydrogeologic, geologic, and water-level data for the groundwater component of the upper Rio Grande focus area study, Colorado, New Mexico, and Texas, United States, and Chihuahua, Mexico, 2017: U.S. Geological Survey data release, https://doi.org/ 10.5066/F7N58KBS.

Huff, G.F., 2004, Simulation of ground-water flow in the basin-fill aquifer of the Tularosa basin, south-central New Mexico, predevelopment through 2040: U.S. Geological Survey Water-Resources Investigations Report 2004-5197, 98 p., accessed June 28, 2020, at https://doi.org/10.3133/ sir20045197.

Hutchison, W.R., and Hibbs, B.J., 2008, Ground water budget analysis and cross-formational leakage in an arid basin: Ground Water, v. 46, no. 3, p. 384-395, accessed June 28, 2020, at https://doi.org/10.1111/j.1745-6584.2008.00446.x.

Isaaks, E.H., and Srivastava, R.M., 1989, An introduction to applied geostatistics: New York, Oxford University Press, $561 \mathrm{p}$.

Ivahnenko, T.I., Flickinger, A.K., Galanter, A.E., DouglasMankin, K.R., Pedraza, D.E., and Senay, G.B., 2021, Estimates of public supply, domestic and irrigation water withdrawal, use, and trends in the upper Rio Grande Basin, 1985 to 2015: U.S. Geological Survey Scientific Investigations Report 2021-5036, xx p., https://doi.org/ $10.3133 / \operatorname{sir} 20215036$.

Jacob, C.E., 1940, On the flow of water in an elastic artesian aquifer: Eos (Washington, D.C.), v. 21, no. 2, p. 574-586, accessed June 28, 2020, at https://doi.org/10.1029/ TR021i002p00574.

Johnson, P.S., and Bauer, P.W., 2012, Hydrogeologic investigation of the northern Taos Plateau, Taos County, New Mexico: New Mexico Bureau of Geology and Mineral Resources Open File Report 544, 96 p., accessed June 28, 2020, at https://geoinfo.nmt.edu/publications/openfile/ downloads/500-599/544/OFR-544_Report.pdf.
Johnson, P.S., Koning, D.J., and Partey, F.J., 2013, Shallow groundwater geochemistry in the Española Basin, Rio Grande rift, New Mexico-Evidence for structural control of a deep thermal source, in Hudson, M.R., and Grauch, V.J.S., eds., New perspectives on Rio Grande rift basins-From tectonics to groundwater: Geological Society of America Special Paper 494, p. 261-301, accessed October 10, 2019, at https://doi.org/10.1130/2013.2494(11).

Karatzoglou, A., Smola, A., and Hornik, K., 2016, kernlabKernel-based machine learning lab: R kernlab package (version 0.9-25), accessed June 28, 2020, at https://CRAN.R-project.org/package=kernlab.

Keller, G.R., and Cather, S.M., eds., 1994, Basins of the Rio Grande rift-Structure, stratigraphy, and tectonic setting: Geological Society of America Special Paper 291, 304 p., accessed June 28, 2020, at https://doi.org/ 10.1130/SPE291.

Kelley, V.C., 1952, Tectonics of the Rio Grande depression of central New Mexico, in Johnson, R.B., and Read, C.B., eds., New Mexico Geological Society, Rio Grande Country, Central New Mexico, 3d annual fall field conference guidebook: Socorro, New Mexico Geological Society, p. 92-105, accessed June 28, 2020, at http://citeseerx.is t.psu.edu/viewdoc/download?doi=10.1.1.508.2766\&rep= rep1\&type $=$ pdf.

Kernodle, J.M., McAda, D.P., and Thorn, C.R., 1995, Simulation of ground-water flow in the Albuquerque basin, central New Mexico, 1901-1994, with projections to 2020: U.S. Geological Survey Water-Resources Investigations Report 94-4251, 114 p., 1 pl., accessed June 28, 2020, at https://doi.org/10.3133/wri944251.

Keyes, C.R., 1905, Geology and underground water conditions of the Jornada del Muerto, New Mexico: U.S. Geological Survey Water-Supply Paper 123, 40 p., accessed June 28, 2020, at https://doi.org/10.3133/wsp123.

Koning, D.J., and Rinehart, A., 2015, Preliminary analysis of the geologic structure of the eastern San Agustin plains, N.M., abs., in New Mexico Geological Society 2015 annual spring meeting, Socorro, New Mexico, April 24, 2015: Socorro, New Mexico Geological Society, proceedings, p. 29, accessed June 28, 2020, at https://nmgs.nmt.edu/ meeting/2015/Spring_Meeting_Program_2015.pdf.

Kunkel, K.E., Stevens, L.E., Stevens, S.E., Sun, L., Janssen, E., Wuebbles, D., Redmond, K.T., and Dobson, J.G., 2013, Regional climate trends and scenarios for the U.S. national climate assessment-Part 5. Climate of the southwest U.S.: National Oceanic and Atmospheric Administration Technical Report NESDIS 142-5, 87 p., accessed December 23, 2020, at https://scenarios.globalchange.gov/ report/regional-climate-trends-and-scenarios-us-nationalclimate-assessment-part-5-climate-southwest. 
Land, L., 2016, Overview of fresh and brackish water quality in New Mexico: New Mexico Bureau of Geology and Mineral Resources Open-File Report 583, 55 p., accessed June 28, 2020, at https://geoinfo.nmt.edu/ publications/openfile/downloads/500-599/583/OFR583_NM_BrackishHR.pdf.

Leonard, G.J., and Watts, K.R., 1988, Hydrogeology and simulated effects of ground-water development on an unconfined aquifer in the closed basin division, San Luis Valley, Colorado: U.S. Geological Survey Water-Resources Investigations Report 87-4284, 42 p., accessed June 28, 2020, at https://doi.org/10.3133/wri874284.

Llewellyn, D., and Vaddey, S., 2013, West-wide climate risk assessment-Upper Rio Grande impact assessment: U.S. Department of the Interior, Bureau of Reclamation, 169 p., accessed June 28, 2020, at https:/www.usbr.gov/ watersmart/baseline/docs/urgia/URGIAMainReport.pdf.

Logan, J.R., 2015, Water rights transfer may dry up Taosarea farm to keep taps flowing in Santa Fe County: Santa Fe New Mexican, March 28, accessed August 14, 2019, at https://www.santafenewmexican.com/news/local news/water-rights-transfer-may-dry-up-taos-area-farm-to/ article_648408bd-71e6-5f9c-b56a-4b5fbcca6226.html.

Lozinsky, R.P., 1987, Cross section across the Jornada del Muerto, Engle, and northern Palomas Basins, south-central New Mexico: New Mexico Geology, v. 9, no. 3, p. 55-64, accessed June 28, 2020, at https://geoinfo.nmt.edu/ publications/periodicals/nmg/9/n3/nmg_v9_n3_p55.pdf.

Macdonald, F.A., Swanson-Hysell, N.L., Park, Y., Lisiecki, L., and Jagoutz, O., 2019, Arc-continent collisions in the tropics set Earth's climate state: Science, v. 364, no. 6436, p. 181-184, accessed November 5, 2020, at https://doi.org/ 10.1126/science.aav5300.

MacDonald, G.M., 2010, Water, climate change, and sustainability in the southwest: Proceedings of the National Academy of Sciences of the United States of America, v. 107 , no. 50, p. 21256-21262, accessed November 4, 2020, at https://doi.org/10.1073/pnas.0909651107.

McAda, D.P., and Barroll, P., 2002, Simulation of groundwater flow in the Middle Rio Grande Basin between Cochiti and San Acacia, New Mexico: U.S. Geological Survey Water-Resources Investigations Report 2002-4200, 81 p., data, accessed on June 28, 2020, at https://doi.org/10.3133/ wri20024200.

McAda, D.P., and Wasiolek, M., 1988, Simulation of the regional geohydrology of the Tesuque aquifer system near Santa Fe, New Mexico: U.S. Geological Survey WaterResources Investigations Report 87-4056, 71 p., accessed June 28, 2020, at https://doi.org/10.3133/wri874056.
Minor, S.A., ed., 2006, The Cerrillos uplift, the La Bajada constriction, and hydrogeologic framework of the Santo Domingo basin, Rio Grande rift, New Mexico: U.S. Geological Survey Professional Paper 1720, 189 p., accessed June 28, 2020, at https://doi.org/10.3133/pp1720.

Montgomery \& Associates and Hutchison, W.R., 2016, Groundwater flow and transport model for Hueco Bolson aquifer: El Paso Water, 138 p.

Moyer, D.L., Anderholm, S.K., Hogan, J.F., Phillips, F.M., Hibbs, B.J., Witcher, J.C., Matherne, A.M., and Falk, S.E., 2013, Knowledge and understanding of dissolved solids in the Rio Grande-San Acacia, New Mexico, to Fort Quitman, Texas, and plan for future studies and monitoring: U.S. Geological Survey Open-File Report 2013-1190, 55 p., accessed June 28, 2020, at https://doi.org/10.3133/ ofr20131190.

Myers, R.G., Everheart, J.T., and Wilson, C.A., 1994, Geohydrology of the San Agustin Basin, Alamosa Creek Basin upstream from Monticello Box, and upper Gila basin in parts of Catron, Socorro, and Sierra Counties, New Mexico: U.S. Geological Survey Water-Resources Investigation Report 94-4125, 70 p., 3 pls., accessed June 28, 2020, at https://doi.org/10.3133/wri944125.

New Mexico Bureau of Geology and Mineral Resources, 2020, Collaborative groundwater monitoring network: New Mexico Bureau of Geology and Mineral Resources database, accessed February 22, 2021, at https://geoinf o.nmt.edu/resources/water/cgmn/home.cfml.

New Mexico Office of the State Engineer, 2016a, Region 3Jemez y Sangre regional water plan: New Mexico Office of the State Engineer, 268 p., accessed September 6, 2019, at https://www.ose.state.nm.us/Planning/region_03.php.

New Mexico Office of the State Engineer, 2016b, Region 7Taos regional water plan: New Mexico Office of the State Engineer, 240 p., accessed September 6, 2019, at https://www.ose.state.nm.us/Planning/region_07.php.

New Mexico Office of the State Engineer, 2016c, Region 14-Rio Chama regional water plan: New Mexico Office of the State Engineer, 240 p., accessed September 6, 2019, at https://www.ose.state.nm.us/Planning/region_14.php.

New Mexico Office of the State Engineer, 2017, Middle Rio Grande regional water plan: New Mexico Office of the State Engineer, 289 p., accessed June 17, 2020, at https:/www.ose.state.nm.us/Planning/documents/ Reg12_MiddleRioGrandeRegionalWaterPlan2017_ Reducedsize.pdf. 
Newton, B.T., 2004, Geologic controls on shallow groundwater quality in the Socorro Basin, New Mexico: New Mexico Institute of Mining and Technology master's thesis, $174 \mathrm{p}$., accessed June 18, 2020, at https://www.nmt.edu/academics/ ees/theses/theses_1936-2014/2004t_newton_bt.pdf.

Newton, T., Kludt, T., Love, D., and Mamer, E., 2015, Hydrogeology of central Jornada del Muerto-Implications for travel along El Camino Real de Tierra Adentro, Sierra, and Doña Ana Counties, New Mexico: New Mexico Bureau of Geology and Mineral Resources Open File Report 573, 62 p., accessed June 28, 2020, at https://geoinfo.nmt.edu/ publications/openfile/details.cfml? Volume $=573$.

Nickerson, E.L., and Myers, R.G.,1993, Geohydrology of the Mesilla ground-water basin, Doña Ana County, New Mexico, and El Paso County, Texas: U.S. Geological Survey Water-Resources Investigations Report 92-4156, 89 p., accessed June 28, 2020, at https://doi.org/10.3133/ wri924156.

Petrossian, R., George, P., Bradley, R.G., Backhouse, S., Boghici, R., and Olden, M.O., 2017, Transborder aquifers-A summary of aquifer properties, policies, and planning approaches for Texas, surrounding states, and Mexico: Texas Water Development Board Groundwater Management Report 17-01, 336 p., accessed November 3, 2020, at http:/www.twdb.texas.gov/groundwater/docs/ GMR_reports/GMR17-01_TransborderAquifers.pdf.

Powell, W.J., and Mutz, P.B., 1958, Ground-water resources of the San Luis Valley, Colorado, with a section on an inflowoutflow study of the area: U.S. Geological Survey WaterSupply Paper 1379, 284 p., 16 pls., accessed November 3, 2020, at https://doi.org/10.3133/wsp1379.

R Development Core Team, 2019, R-A language and environment for statistical computing, version 3.6.1: R Foundation for Statistical Computing, accessed June 28, 2020, at https://www.R-project.org.

Rio Grande Water Conservation District, 2018, Special improvement district \# 1 of the Rio Grande water conservation district-Annual report for the 2017 plan year: Rio Grande Water Conservation District, 36 p., accessed July 25, 2019, at https://rgwcd.org/attachments/subdistrict1/ AP/2017_Annual\%20Report_final.pdf.

Ritchie, A.B., Galanter, A.E., and Curry, L.T.S., 2019, Groundwater-level change for the periods 2002-8, 2008-12, and 2008-16 in the Santa Fe Group aquifer system in the Albuquerque area, central New Mexico: U.S. Geological Survey Scientific Investigations Map 3435, 1 sheet, 16 p., accessed September 2, 2020, at https://doi.org/ $10.3133 / \operatorname{sim} 3435$.
Ritchie, A.B., Hanson, R.T., Galanter, A.E., Boyce, S.E., Damar, N.A., Shephard, Z.M., and Tillman, F.D., 2018, Digital hydrologic and geospatial data for the Rio Grande transboundary integrated hydrologic model and wateravailability analysis, New Mexico and Texas, United States, and northern Chihuahua, Mexico: U.S. Geological Survey data release, accessed September 2, 2020, at https://doi.org/ 10.5066/P9J9NYND.

Roybal, F.E., 1991, Ground water resources of Socorro County, New Mexico: U.S. Geological Survey WaterResources Investigations Report 89-4083, 103 p., 2 pls., accessed June 28, 2020, at https://doi.org/10.3133/ wri894083.

Ruleman, C.A., Thompson, R.A., Shroba, R.R., Anderson, M., Drenth, B.J., Rotzien, J., and Lyon, J., 2013, Late Miocene-Pleistocene evolution of a Rio Grande rift subbasin, Sunshine Valley-Costilla Plain, San Luis Basin, New Mexico and Colorado, in Hudson, M.R., and Grauch, V.J.S., eds., New perspectives on Rio Grande rift basins-From tectonics to groundwater: Geological Society of America Special Paper 494, p. 47-73, accessed November 3, 2020, at https://doi.org/10.1130/2013.2494(03).

S.S. Papadopulos and Associates, Inc., 2002, SSPA groundwater study Rio Grande and La Jencia basins, app. E2 of Socorro-Sierra planning region water planning studyGroundwater resources in the Rio Grande and La Jencia basins: New Mexico Interstate Stream Commission, 200 p., accessed November 2, 2020, at https://www.ose.state.nm.us/ Planning/RWP/Regions/15_SocorroSierra/2003/Volume-2/ Appendix-E2.pdf.

S.S. Papadopulos and Associates, Inc., 2006, Riparian groundwater models for the Middle Rio Grande-ESA collaborative program FY04: New Mexico Interstate Stream Commission, 58 p., accessed June 28, 2020, at https://www.ose.state.nm.us/Basins/RioGrande/MRGESA/ RiparianModelReportFY04.pdf.

Sangre de Cristo National Heritage Area, 2019, Water, with a section on Aquifers and artesian wells: Sangre de Cristo National Heritage Area web page, accessed October 23, 2020, at https://www.sangreheritage.org/water/.

Seager, W.R., 2005, Geologic map of the Prisor Hill 7.5- minute Quadrangle, Sierra County, New Mexico: New Mexico Bureau of Geology and Mineral Resources Open-File Geologic Map 114, 1:24,000 scale, 35 p., data, accessed June 25, 2020, at https://geoinfo.nmt.edu/publications/maps/ geologic/ofgm/details.cfml? Volume=114.

Seequent Ltd, 2020, Transform data into decisions with Oasis montaj: Seequent Ltd. web page, accessed February 5, 2021, at https://www.seequent.com/products-solutions/ geosoft-oasis-montaj/. 
Sheng, Z., 2013, Impacts of groundwater pumping and climate variability on groundwater availability in the Rio Grande Basin: Ecosphere, v. 4, no. 1, p. 1-25, accessed June 23, 2020, at https://doi.org/10.1890/ES12-00270.1.

Sheng, Z., and Devere, J., 2005, Understanding and managing the stressed Mexico-USA transboundary Hueco Bolson aquifer in the El Paso del Norte region as a complex system: Hydrogeology Journal, v. 13, no. 5-6, p. 813-825. [Also available at https://doi.org/10.1007/s10040-005-0451-8.]

Sheppard, P.R., Comrie, A.C., Packin, G.D., Angersbach, K., and Hughes, M.K., 2002, The climate of the US southwest: Climate Research, v. 21, no. 3, p. 219-238, accessed December 15, 2020, at https://doi.org/10.3354/cr021219.

Stringam, B., Shukla, M., and Kuffour, B.N.O., 2016, Assessment of water table and water quality variations with respect to river flow along the Rio Grande between Garfield, NM and the New Mexico-Texas border: New Mexico Water Resources Research Institute Technical Completion Report 372, 35 p., accessed June 28, 2020, at https://nmwrri .nmsu.edu/wp-content/uploads/2015/publish/techrpt/tr372/ tr372.pdf.

Summers, W.K., 1975, Ground-water resources of the village of Magdalena, Socorro County, New Mexico-A hydrologic report on the results of test drilling during February 1975: Santa Fe, Ralph E. Vail Consulting Engineers, $17 \mathrm{p}$.

Sweetkind, D.S., 2017, Three-dimensional hydrogeologic framework model of the Rio Grande transboundary region of New Mexico and Texas, USA, and northern Chihuahua, Mexico: U.S. Geological Survey Scientific Investigations Report 2017-5060, 49 p., 2 apps., accessed November 3, 2020, at https://doi.org/10.3133/sir20175060.

Swetnam, T.W., and Betancourt, J.L., 1998, Mesoscale disturbance and ecological response to decadal climatic variability in the American southwest: Journal of Climate, v. 11 , no. 12 , p. $3128-3147$, accessed December 10, 2020, at https://doi.org/10.1175/1520-0442(1998)011<3128:MDA ERT>2.0.CO;2.

Teeple, A.P., 2017, Geophysics- and geochemistry-based assessment of the geochemical characteristics and groundwater-flow system of the U.S. part of the Mesilla basin/Conejos-Médanos aquifer system in Doña Ana County, New Mexico, and El Paso County, Texas, 2010-12: U.S. Geological Survey Scientific Investigations Report 2017-5028, 183 p., accessed November 3, 2020, at https://doi.org/10.3133/sir20175028.
Terracon; John Shomaker \& Associates, Inc.; Livingston Associates, LLC, Inc.; Zia Engineering and Environmental, Inc.; and Sites Southwest, 2003, The New Mexico lower Rio Grande regional water plan: New Mexico Office of the State Engineer, 238 p., accessed July 27, 2016, at https://www.ose.state.nm.us/Planning/RWP/11_LRG/1999/ LOWER-RIO-GRANDE-REGIONAL-WATER-PLAN.pdf.

Texas Water Development Board, 2019a, Groundwater database (GWDB) reports: Texas Water Development Board web page, accessed April 1, 2017, at http://www.twdb. texas.gov/groundwater/data/gwdbrpt.asp.

Texas Water Development Board, 2019b, Major aquifers of Texas: Texas Water Development Board web page, accessed October 9, 2019, at http://www.twdb.texas.gov/ groundwater/aquifer/major.asp.

Thompson, R.A., and McMillan, N.J., 1992, A geologic overview and one-day field guide of the Taos Plateau volcanic field, Taos County, New Mexico: U.S. Geological Survey Open-File Report 92-528, 23 p., accessed June 28, 2020, at https://doi.org/10.3133/ofr92528.

Tiedeman, C.R., Kernodle, J.M., and McAda, D.P., 1998, Application of nonlinear-regression methods to a groundwater flow model of the Albuquerque basin, New Mexico: U.S. Geological Survey Water-Resources Investigations Report 98-4172, 90 p., accessed June 28, 2020, at https://doi.org/10.3133/wri984172.

Timmons, S.S., 2013, An update on the hydrogeology of Magdalena, Socorro County, New Mexico: New Mexico Bureau of Geology and Mineral Resources Open-File Report 556, 19 p., app., accessed September 18, 2019, at https://geoinfo.nmt.edu/publications/openfile/details.cfml? Volume $=556$.

Turner, S., 2019, Decision denying water permit appealed: Albuquerque Journal, September 23, accessed October 23, 2020, at https://www.abqjournal.com/1370059/decisiondenying-water-permit-appealed.html.

U.S. Department of the Interior, 2021, WaterSMART: U.S. Department of Interior website, accessed April 28, 2021, at https://www.doi.gov/watersmart.

U.S. Geological Survey, 2017, USGS water data for the nation-U.S. Geological Survey National Water: Information Systems, accessed September 21, 2017, at https://doi.org/10.5066/F7P55KJN.

U.S. Geological Survey, 2020, Administrative feature names: U.S. Board on Geographic Names database, accessed December 23, 2020, at https://geonames.usgs.gov/apex/f?p=

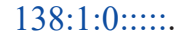


Utton Transboundary Resources Center, 2015, Inter-basin water transfers, chap. 19 of Water matters: University of New Mexico School of Law, p. 19-1-19-10, accessed September 20, 2019, at https://uttoncente r.unm.edu/resources/research-resources/water-matters2015--full-pdf.pdf.

Weeden, A.C., Jr., and Maddock, T., III, 1999, Simulation of groundwater flow in the Rincon Valley area and Mesilla basin, New Mexico and Texas: University of Arizona Technical Reports on Hydrology and Water Resources HWR 99-020, 181 p., accessed June 28, 2020, at https://repository.arizona.edu/handle/10150/617629.

Wilkins, D.W., 1986, Geohydrology of the southwest alluvial basins regional aquifer-system analysis in parts of Colorado, New Mexico, and Texas: U.S. Geological Survey Water-Resources Investigations Report 84-4224, 61 p., 7 pls., accessed June 28, 2020, at https://doi.org/10.3133/ wri844224.
Wilkins, D.W., 1998, Summary of the southwest alluvial basins regional aquifer-system analysis in parts of Colorado, New Mexico, and Texas, chap. A of Regional aquifersystem analysis: U.S. Geological Survey Professional Paper 1407-A, p. A1-A49 p., accessed September 20, 2019, at https://doi.org/10.3133/pp1407A.

Wood, S.N., 2017, Generalized additive models-An introduction with R $(2 \mathrm{~d}$ ed.): Boca Raton, Fla., Chapman and Hall/CRC Press, 476 p., accessed June 23, 2020, at https://doi.org/10.1201/9781315370279.

Woodhouse, C.A., Meko, D.M., MacDonald, G.M., Stahle, D.W., and Cook, E.R., 2010, A 1200-year perspective of 21st century drought in southwestern North America: Proceedings of the National Academy of Sciences of the United States of America, v. 107, no. 50, p. 21283-21288, accessed December 17, 2020, at https://doi.org/10.1073/ pnas.0911197107. 

For more information, contact:

Director, Oklahoma-Texas Water Science Center

U.S. Geological Survey

1505 Ferguson Lane

Austin, TX 78754-4501

https://www.usgs.gov/centers/ot-water

Publishing support provided by the

Pembroke Publishing Service Center 

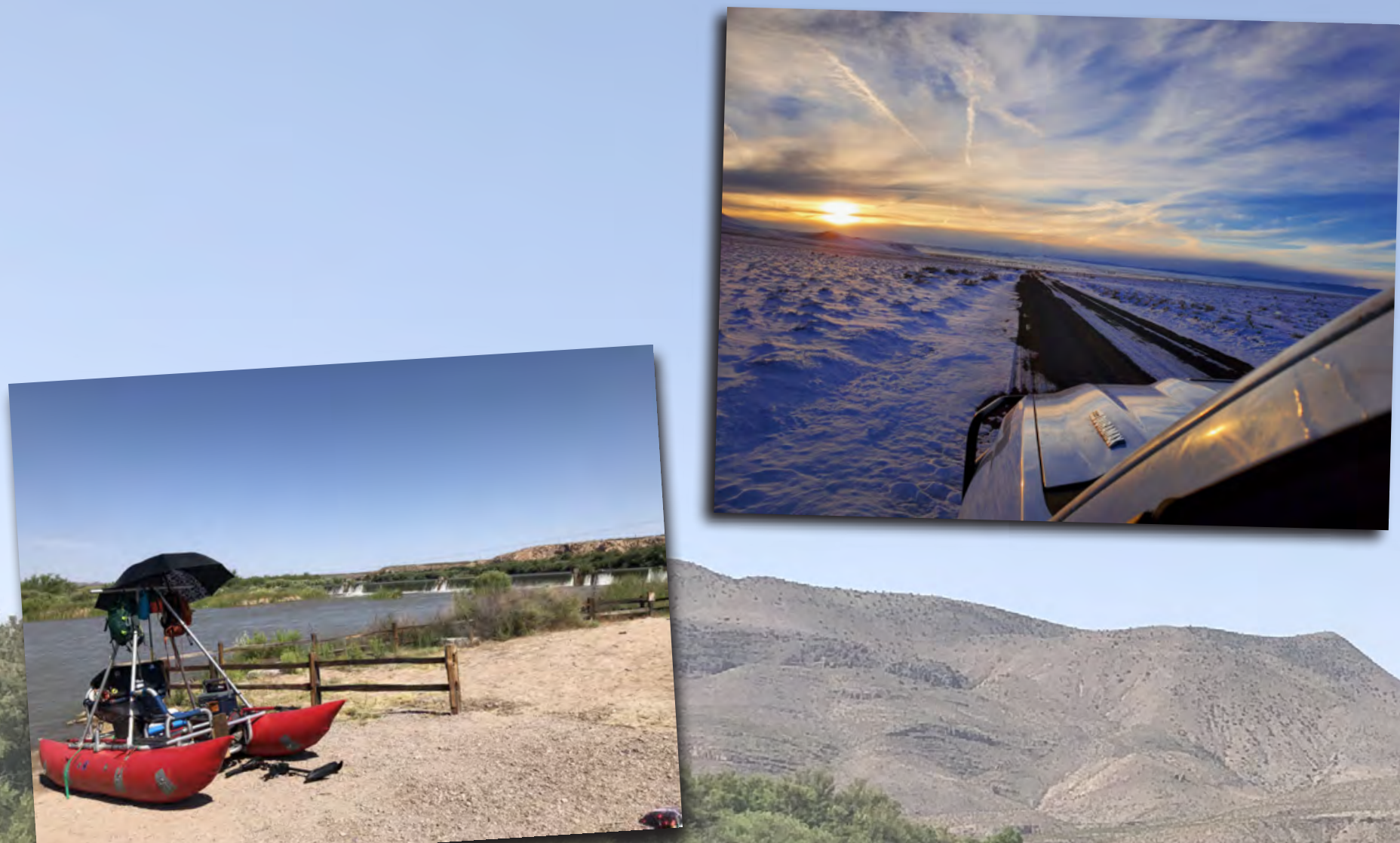

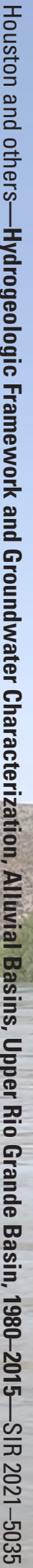

